\title{
VETERAN NARRATIVES AND THE COLLECTIVE MEMORY OF THE VIETNAM WAR
}

A Dissertation

Submitted to

the Temple University Graduate Board

In Partial Fulfillment

of the Requirements for the Degree

DOCTOR OF PHILOSOPHY

by

John A. Wood

August, 2011

Examining Committee Members:

Kenneth L. Kusmer, Advisory Chair, Department of History, Temple University Gregory J.W. Urwin, Department of History, Temple University

James Hilty, Department of History, Temple University

Stanley N. Katz, External Member, Princeton University 
Copyright

2011

by

John Wood 


\begin{abstract}
This dissertation is a comprehensive study of the content, author demographics, publishing history, and media representation of the most prominent Vietnam veteran memoirs published between 1967 and 2005. These personal narratives are important because they have affected the collective memory of the Vietnam War for decades. The primary focus of this study is an analysis of how veterans' memoirs depict seven important topics: the demographics of American soldiers, combat, the Vietnamese people, race relations among U.S. troops, male-female relationships, veterans' postwar lives, and war-related political issues. The central theme that runs through these analyses is that these seven topics are depicted in ways that show veteran narratives represent constructed memories of the past, not infallible records of historical events. One reoccurring indication of this is that while memoirists' portrayals are sometimes supported by other sources and reflect historical reality, other times they clash with facts and misrepresent what actually happened.

Another concern of this dissertation is the relationship of veteran memoirs to broader trends in public remembrance of the Vietnam War, and how and why some books, but not others, were able to achieve recognition and influence. These issues are explored by charting the publishing history of veteran narratives over a thirty-eight year
\end{abstract}


period, and by analyzing media coverage of these books. This research indicates that mainstream editors and reviewers selected memoirs that portrayed the war in a negative manner, but rejected those that espoused either unambiguous anti- or pro-war views. By giving some types of narratives preference over others, the media and the publishing industry helped shape the public's collective understanding of the war. 


\section{ACKNOWLEDGEMENTS}

Many people have made the completion of this dissertation possible. Various fellowships and grants awarded to me by Temple University have been a great financial support throughout my graduate school career. My advisor, Dr. Kenneth L. Kusmer, provided invaluable guidance from the very beginning of my graduate studies. He has worked tirelessly over the last few years as a reviewer and editor of chapter drafts, pushing me to improve my writing and hone my arguments. I have also benefited from the considerable knowledge and experience possessed by the other members of my dissertation committee, Dr. Gregory J.W. Urwin and Dr. James Hilty. In the latter stages

of the dissertation process, Dr. Stanley Katz of Princeton University generously agreed to serve as the committee's outside reader. Finally, I am lucky to have friends and family that have kept me sane while working on this project. You have all kept me afloat during the rough spots. No one, however, has helped me more through this process than my parents. Without your support I never would have made it this far. This dissertation is dedicated to you. 


\section{TABLE OF CONTENTS}

PAGE

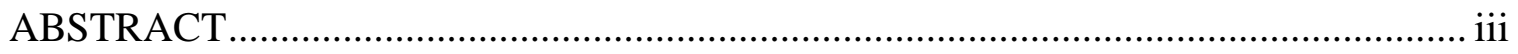

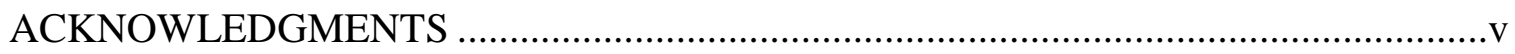

\section{CHAPTER}

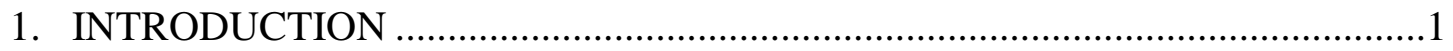

2. WHO WERE THE VIETNAM VETERAN MEMOIRISTS ? ................................13

3. COMBAT CONDITIONS AND THE VIETNAMESE PEOPLE …………….......40

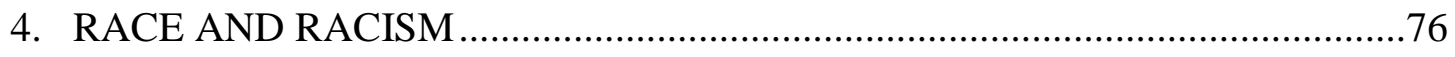

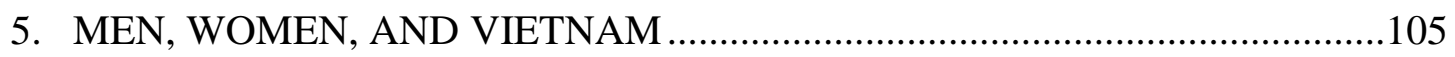

6. THE RETURN HOME AND LIFE AFTER VIETNAM ……………..................132

7. THE POLITICAL CONTENT OF VETERAN NARRATIVES .........................171

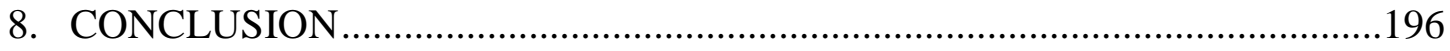

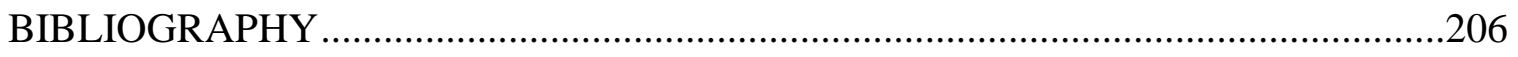




\section{CHAPTER ONE}

\section{INTRODUCTION}

In December 1983, The New York Times announced that publishers and readers had "rediscovered Vietnam." There had been a handful of successful books about the war before then, the Times explained, but in 1983, "books about Vietnam [were] rolling off the presses in record numbers," and libraries and bookstores were eagerly stocking their shelves with such works. ${ }^{1}$ In 1987, the Times reported that the "Vietnam-Book Boom" was still in full swing, and it asked several authors of books about the war to give their thoughts on this "latest artistic trend."2 One of the authors, Philip Caputo, who had fought as a Marine in Vietnam, dismissed this trend as "Vietnam chic." Caputo speculated that the heightened public interest in the war would soon fade, and readers would move on to books about other conflicts. ${ }^{3}$

Interest in the Vietnam War and books about that conflict may have climaxed in the 1980's, but Caputo was wrong in thinking that such books were only a passing fad. Hundreds of titles about the war appeared in the years following the Times article, and many of them were written by American veterans of the conflict. Although veteran-

\footnotetext{
${ }^{1}$ Edwin McDowell, “Publishing: Vietnam Rediscovered," The New York Times, 2 Dec. 1983, C25.

2 "4 Writers Try to Make Sense of the Vietnam-Book Boom," The New York Times, 4 August 1987,

${ }^{3}$ Ibid.
} C17. 
authors produced some well-known Vietnam War fiction, it was veterans' memoirs, such as Caputo's A Rumor of War, ${ }^{4}$ that comprised the great majority of veteran-authored titles about the conflict. A number of these books were critically and commercially successful, as were several titles that featured the personal accounts of Vietnam veterans in the form of oral histories. Today, anyone perusing the shelves of a chain book store will likely find that a large portion of the titles in its "Vietnam War section" are veterans' memoirs and oral histories.

Due to their quantity and longtime popularity, veterans' memoirs, like films, novels, news media coverage, political rhetoric, and other influential cultural products, have been important to the construction of the nation's collective memory of the war. Millions of Americans, over several decades, have learned about the war--at least in part-by reading veterans' narratives. Despite the importance of these books, however, they have hitherto received inadequate treatment by scholars. Veterans' memoirs have frequently been used in historical scholarship, but almost always simply as primary sources to support various arguments about the war. ${ }^{5}$ Virtually no historians have regarded the Vietnam veteran narrative genre as a topic in itself, much less explored the

\footnotetext{
${ }^{4}$ Philip Caputo, A Rumor of War (New York: Holt, Rinehart and Winston, 1977; Owl Books, 1996).

${ }^{5}$ Numerous historians who have written about the Vietnam War have used veterans' memoirs and oral histories as primary sources, but most do so only sparingly. A few historians, however, use these sources extensively, such as Christian G. Appy in Working-Class War: American Combat Soldiers and Vietnam Working-Class War: American Combat Soldiers and Vietnam (Chapel Hill, NC: The University of North Carolina Press, 1993), and Peter S. Kindsvatter in American Soldiers: Ground Combat in the World Wars, Korea, and Vietnam (Lawrence, KS: Kansas University Press, 2003), which is almost completely based on veterans' memoirs. As a result, there are a few instances where my findings overlap those of other historians. Crucially, though, this dissertation uses the information gleaned from veterans' narratives to analyze how former soldiers portrayed various aspects of the war, and how these portrayals affected what readers learned about the conflict. Other historians treated these works as primary sources only useful for determining what happened in Vietnam.
} 
potential effects of these works on America's collective memory. ${ }^{6}$ Literary scholars have done much analysis of veterans' narratives, but their scholarship is also deficient in several ways. These writers often discussed just a few memoirs, made no distinctions between nonfiction narratives and veteran-authored fiction, ${ }^{7}$ and focused on collective memory only in terms of how former soldiers portrayed certain aspects of the war, such as race relations. ${ }^{8}$

Veterans' narratives are important and deserve much more than the limited attention they have received so far from historians and other scholars. This dissertation will be the first comprehensive study of these documents. At the heart of the study are fifty-five veterans' memoirs and three veteran oral history compilations. These books represent the most prominent narratives published between 1967 and $2005,{ }^{9}$ and were chosen for analysis because they were bestsellers, award winners, reviewed in The New

\footnotetext{
${ }^{6}$ The only existing work of historical scholarship that regards veterans' narratives as a separate topic, or examines the potential effects of such works on collective memory, is a 1986 Journal of American History review of nonfiction Vietnam War books by George Herring. George C. Herring, "Vietnam Remembered," The Journal of American History 73, no. 1 (June 1986): 152-164.

${ }^{7}$ The most significant examples of such scholarship are: Philip D. Beidler, American Literature and the Experience of Vietnam (Athens, GA: University of Georgia Press, 1982); James C. Wilson, Vietnam in Prose and Film (Jefferson, NC: McFarland \& Company, 1982); Jeffrey Walsh, American War Literature, 1914 to Vietnam (New York: St. Martin's Press, 1982), 185-208; Thomas Myers, Walking Point: American Narratives of Vietnam (New York: Oxford University Press, 1988); Philip K. Jason, ed., (Fourteen Landing Zones: Approaches to Vietnam War Literature (lowa City, IA: University of lowa Press, 1991); Philip D. Beidler, Re-Writing America: Vietnam Authors in Their Generation (Athens, GA: University of Georgia Press, 1991); Tobey C. Herzog, Vietnam War Stories: Innocence Lost (New York: Routledge, 1992); Andrew Martin, Receptions of War: Vietnam in American Culture (Norman, OK: University of Oklahoma Press, 1993); Samuel Hynes, The Soldiers' Tale: Bearing Witness to Modern War (New York: Allen Lane/The Penguin Press, 1997), 177-222; and Julia Bleakney, Revisiting Vietnam: Memoirs, Memorials, Museums (New York: Routledge, 2006).

${ }^{8}$ See Herman Beavers, "Contemporary Afro-American Studies and the Study of the Vietnam War," Vietnam Generation 1, no. 2 (1989): 6-13; and Perry D. Luckett, "The Black Soldier in Vietnam War Literature and Film," War, Literature, and the Arts 1, no.2 (1989-90): 1-27.

91967 is the year the first Vietnam veteran memoir was published: Donald Duncan, The New Legions (New York: Random House, 1967). 2005 was chosen in order to give the study an end point in the twenty-first century.
} 
York Times or other major publications, written by famous people, or referenced in scholarship. Only prominent narratives were included in this group because only titles that achieved recognition could have had significant impact on the nation's collective memory.

In a special issue of the Journal of American History devoted to memory, David Thelen writes that "memory, private and individual as much as collective and cultural, is constructed, not reproduced." ${ }^{\prime 10}$ He adds, "this construction is not made in isolation but in conversations with others that occur in the contexts of community, broader politics, and social dynamics."11 The above statements clearly apply to veterans' narratives. These works are not infallible records of historical events, but constructed memories affected by external forces and the passage of time. These accounts sometimes reflect an objective perspective and are supported by other sources. At other times, they clash with facts and misrepresent what actually happened. This overarching premise is explored by analyzing how veterans portrayed specific aspects of the war and its aftermath in their memoirs.

Chapter 2 systematically analyzes the demographics and backgrounds of fifty-one veteran-authors for whom sufficient information is available. Demographic data gleaned from the memoirs and other sources were organized into a variety of categories, including age, amount of time served in Vietnam, education level, and length of military service. These data are important because social, economic and educational level helped determine both what an author experienced in Vietnam and how he or she interpreted

${ }^{10}$ David Thelen, "Memory and American History," The Journal of American History 75, no. 4 (March 1989), 1119.

${ }^{11}$ Ibid. 
these experiences. Those factors in turn influenced how aspects of the war would be portrayed in the veteran's memoir.

Research into the background of the memoirists determined that the majority were white, college graduates, and officers; on average, twenty-seven-years old when they served in Vietnam. These statistics are potentially troubling because ground combat in the war was primarily fought by men of opposite backgrounds: poor and working-class white and minority enlisted personnel, many of whom went to war before their twentieth birthdays. This demographic disparity suggests that memoirs were written by former soldiers who did not share the same experiences and viewpoints as the average American combat soldier.

Closer examination of the authors' demographic data, however, casts doubt on this conclusion. The authors fall into three distinct rank-based groups. The first group consists of ten veterans who served as high-ranking officers in Vietnam; the second is composed of fifteen men who fought as low-ranking enlisted men. The third and largest group, twenty-six individuals, went to war as low-ranking, "junior" commissioned officers. Although the ten senior officers are most unlike average combat troops in demographics and background, there are gulfs separating the former junior officers from low-level enlisted men as well. Specifically, the junior-officer memoirists had higher education and social-class levels than most of the enlisted "grunts" that fought in Southeast Asia. The junior officers, however, unlike their higher-ranking counterparts, lived, fought, and sometimes died alongside the enlisted men they commanded in Vietnam. It is unfortunate that the disproportionately poor, nonwhite, and teenaged enlisted men who did most of the fighting for the United States were not better 
represented among the memoirists. The existence of so many former junior officers among the authors nevertheless ensures that even though most authors were not grunts in background, most were grunts by measure of their wartime experiences.

Subsequent chapters in the dissertation examine and assess the portrayals of warrelated topics in veterans' narratives. Chapter 3 explores the interrelated issues of combat conditions and the Vietnamese people. Most veterans describe combat in a graphic, unromantic manner. Their negative depictions of warfare in Vietnam as frustrating, chaotic, and seemingly futile are supported by other sources, adding up to a searing indictment of America's efforts in Vietnam. It is strange, then, that these accounts simultaneously offer a negative portrayal of the war's greatest victims: Vietnamese civilians. The Vietnamese people are depicted in most memoirs as either two-faced enemy collaborators or greedy exploiters of American GIs, and rarely do they appear in narratives as anything more than racist, one-dimensional caricatures. Other sources indicate that Vietnamese behaviors that many GIs loathed were understandable in the context of Vietnam's culture and history. Memoirists frequently suggest, for instance, that American soldiers were irritated by the seemingly constant presence of beggars, peddlers, pimps, and other Vietnamese in search of U.S. dollars. They do not explain that many South Vietnamese were forced into such activities because the war had wrecked their nation's economy.

The manner in which the war and Vietnamese civilians are portrayed in the narratives is related to their limited scope. Memoirs are excellent tools for learning about American soldiers' battlefield experiences, for these individuals witnessed the fighting firsthand; and fortunately, most veterans offered uncensored and unsanitized accounts of 
these experiences. But such accounts are inadequate for learning how the Vietnamese themselves experienced the war, because most GIs, like most other Americans, were largely ignorant of Vietnam's language, history, and culture. It is no fault of the veterans that their personal narratives do not exhibit a nuanced understanding of the Vietnamese people, but the fact remains that these documents suffer from a limited scope in that regard.

Perhaps the most striking demographic characteristic of the prominent memoirists is the fact that all but six of them were white, even though African Americans and other nonwhites fought in disproportionate numbers in Vietnam. Race relations was an important issue in the Vietnam-era military, but most white veterans make no mention of the subject in their narratives. An analysis of the memoirs of nonwhite veterans, regardless of their level of prominence, demonstrates that they constitute a race-centric "counter-memory" of the war. This nonwhite interpretation of the conflict consists of two competing, antagonistic paradigms. The competition between these two versions occurs between different memoirs, as some nonwhite authors emphasize one perspective over the other; but these two paradigms are also sometimes evident within single narratives.

One version of the nonwhite narrative offers a portrayal of the war that is reminiscent of the positive attitude that African Americans and other nonwhites have traditionally held towards wartime military service. This approach is composed of two parts: emphasis on racial cooperation and friendship, and expression of pride in the performance of one's own racial or ethnic group in combat. The second nonwhite view of the war is, in many ways, the opposite of the first; it focuses on incidents of white 
racism and self-segregation and features condemnations of the Vietnam experience. The second version is seemingly influenced by aspects of Black Power movement ideology, including racial separation, cultural nationalism, and worldwide solidarity among nonwhite peoples.

Chapter 5 analyzes how issues related to women and gender relations are portrayed in veterans' memoirs. Though interactions between soldiers and women appear throughout these accounts, few scholars have dealt with these topics. In order to fully explore these neglected gender issues, this chapter considers what happened and how it was portrayed, and provides counterbalancing perspectives on this aspect of the memoirs. The veterans suggest that a generally sexist and misogynist attitude was displayed by GIs in their interactions with members of the opposite sex, including Vietnamese women, U.S. military nurses and other American women in Vietnam, as well as women they encountered on Rest and Recuperation ("R\&R") trips to Asian countries. The narratives and supplemental sources show that the primary reasons for this behavior were rooted in aspects of military and mainstream culture that promoted hostility towards women and the belief that sex is the right of every soldier during wartime. Women of all types were viewed in this demeaning manner, but a pervasive racism among the troops meant that the intensity of these attitudes was heightened when dealing with Asian women.

Although the memories of soldiers who served in Vietnam are invaluable resources for learning what happened there and why, they are nonetheless fallible and subjective in how they portray the past. For this reason, it is equally important to analyze how veterans depict what happened, and how these depictions mirror the attitudes and 
behaviors they documented. By making light of or romanticizing situations in which GIs displayed sexist, misogynistic, or racist behavior, many former soldiers show that at the time they recalled these events, usually years after the war ended, they still approved of them. Moreover, women are often depicted in ways that indicate negative or stereotyped attitudes: Asian women as submissive, American women as domineering, any woman in a war zone as an object of sexual gratification, and so forth.

The attitudes and experiences of veterans are not monolithic. The perspectives they offer are inherently limited because all but a few of the memoirs are written by men. The memoirs of American and Vietnamese women provide a different perspective, a counter-memory, just as nonwhite narratives offer a counter-memory in regards to racial issues. These women experienced many of the same events as the men, and their recollections often support those of their male counterparts. The same sexist attitudes and behaviors that male veterans recall as having characterized male-female interactions in Vietnam were reported by women as well. As the victims of this behavior, however, women obviously experienced it very differently, and their portrayals stand in sharp contrast to the depictions offered by the men. Like the memoirs of African Americans, the female perspectives from outside the primary memoir group highlight the fact that veterans' accounts often provide only a limited viewpoint on what happened in Vietnam.

Chapter 6 analyzes how memoirists portray the homecomings and postwar lives of American veterans of the Vietnam War. As is the case with veterans' portrayals of other topics, the return of Vietnam veterans to America is depicted in ways that both reflect and distort historical reality. Many veterans forthrightly admit in their narratives that they suffered from psychological problems and other readjustment issues when they 
came home from Southeast Asia. An extensive postwar U.S. government study confirms that many Vietnam veterans, especially those who, like most memoirists, saw heavy combat, experienced war-related psychological issues when they came home. ${ }^{12}$ On the other hand, narratives also feature three common themes that are not supported by other sources: the suggestion that troops returning from Vietnam had worse homecomings than soldiers of previous wars; stories of being harassed by American civilians; and the opinion that most Vietnam veterans eventually fully recovered from their readjustment problems.

The inaccuracies in veterans' depictions of their homecomings are unfortunate, but nevertheless unintentional. Memoirists felt themselves to be unique among history's warriors in their postwar troubles; but they, like most Americans, were probably unaware that throughout the history of warfare soldiers have encountered similar problems in readjusting to civilian life. Many narratives include dubious stories about civilians abusing returning soldiers, because veterans' memories were likely distorted by external influences in the years that passed between when they came home and when they produced their memoirs. These types of memory problems are not unique to Vietnam veterans. Personal memory is inherently flawed. Finally, stories of eventual recovery and success are overly prevalent in veterans' narratives because memoirists' exceptional backgrounds made them better equipped to succeed in the postwar world than most Americans who fought in Vietnam.

\footnotetext{
${ }^{12}$ The study, the National Vietnam Veterans Readjustment Study (NVVRS), completed in 1988, was an investigation into the mental health of Vietnam veterans. Its primary goal was to determine the extent to which veterans suffered from post-traumatic stress disorder (PTSD). For more on these issues see Chapter 6.
} 
The final chapter discusses the political messages conveyed by veterans' memoirs, beginning with the difficult and complicated question of whether they convey a generally "anti-war" or "pro-war" stance. Many memoirs include statements of unambiguous opposition, even hatred, of the war, and they offer an overall negative portrayal of America's Vietnam experience. Memoirists may often express hatred of the war, but they express hatred of the anti-war movement as well. Many veterans, even the harsh critics of the war, express pride in their combat tours and suggest that they have not entirely abandoned the positive attitudes towards military service that led many to join the military in the first place. ${ }^{13}$

This chapter concludes by exploring why veterans' narratives that conveyed these messages about the war achieved the most success. The New York Times and other prominent periodicals helped determine the failure or success of memoirs by choosing certain books to review. To a significant degree, reviews in mainstream publications disproportionately affected how many people read a Vietnam memoir. The narratives reviewed by these publications that received the most attention were those that portrayed the war in a nuanced, but generally negative light. Memoirs that conveyed decisively right-wing or left-wing conceptions of the Vietnam conflict did not receive nearly as much attention or praise from mainstream reviewers. Yet, the political content of memoirs also conformed to how Vietnam veterans as a group feel about the conflict. Like many in the small minority of their population who produced narratives, most Vietnam veterans, according to opinion polls, thought the war was a mistake. But they

\footnotetext{
${ }^{13}$ Only seven out of the fifty-one most prominent memoirists were drafted into the military. And most who volunteered said they joined up to serve their country, "become a man," carry on family tradition, and so forth. Relatively few say they volunteered to avoid the draft, which is why many men enlisted during the Vietnam era. For a discussion of these issues see Chapter 2.
} 
also disliked anti-war protestors, remained patriotic, and were proud that they served their country. ${ }^{14}$ In this sense, at least, the veterans' memoirs accurately reflected the conflicted views of most of the American servicemen and women who participated in the Vietnam conflict.

${ }^{14}$ The opinion polls were conducted during the late 1970's as part of two government studies: Myths and Realities: A Study of Attitudes Toward Vietnam Era Veterans (Washington: United States Government Printing Office, 1980), and Legacies of Vietnam: Comparative Adjustment of Veterans and their Peers (Washington: United States Government Printing Office, 1981). The findings of these studies are discussed in Chapter 7. 


\section{CHAPTER TWO}

\section{WHO WERE THE VIETNAM VETERAN MEMOIRISTS?}

Lewis Puller, Jr., author of the memoir, Fortunate Son, always knew he would join the Marines someday and, with luck, command troops against America's enemies on the battlefield. This eagerness for combat was a product of his upbringing, for his father was a Marine Corps legend, Lewis "Chesty" Puller, Sr., and the elder Puller raised his son to see fighting for one's country as a duty and an honor. It was completely natural for the younger Puller to enter Marine Corps officer training immediately after college graduation and, when training ended a few months later, to volunteer to lead an infantry platoon in Vietnam. Puller, however, had many disillusioning experiences during his combat tour, and chief among them was the day he realized he was very much unlike the enlisted men under his command. Whereas Puller was a college graduate who grew up in comfortable economic circumstances, half of his men were high school drop-outs, and all came from "lower-middle-class backgrounds." He also learned that, at age twenty-three, he was an "old man" compared to the "teenage misfits" who composed the bulk of the platoon. ${ }^{1}$

As the son of a famous general and war hero, Puller grew up in exceptional circumstances, but he was not the only former-officer-turned-memoirist who discovered that his own background differed greatly from those of his men. William Broyles, Jr.,

\footnotetext{
${ }^{1}$ Lewis B. Puller, Jr., Fortunate Son (New York: Grove Weindenfeld, 1991), 1-33, 73, 77, 78.
} 
who had already earned a M.A. degree from prestigious Oxford University when he joined the Marines in $1968,{ }^{2}$ wrote this entry in his journal after meeting his troops in Vietnam for the first time:

I have fifty-eight men. Only twenty have high school diplomas. About ten of them are over twenty-one. Reading through their record books almost made me cry. Over and over they read---address of father: unknown; education: one or two years of high school; occupation: laborer, pecan sheller, gas station attendant, Job Corps. Kids with no place to go. No place but here. ${ }^{3}$

Both Puller and Broyles served their combat tours relatively late in the war, a period when many GIs in Vietnam were only there because they lacked the money, connections, and know-how needed to procure a draft deferment. Philip Caputo, however, who led an infantry platoon in the opening stages of America's ground war in Vietnam, was also struck by the generally disadvantaged backgrounds of his troops. He wrote in his acclaimed memoir, A Rumor of War, that many in his platoon had never finished high school, and that most came "from city slums and dirt farms and Appalachian mining towns." ${ }^{, 4}$ Everyone in the platoon was a volunteer, but Caputo speculated that many enlisted only to avoid the draft, or because the military offered "a guaranteed annual income, free medical care, [and] free clothing." ${ }^{, 5}$ Caputo was not the son of a war hero, or the graduate of a famed European university, but as a college graduate from a middle-class family, his upbringing was nevertheless privileged in comparison with those of his men.

\footnotetext{
${ }^{2}$ William Broyles, Jr., Brothers in Arms: A Journey from War to Peace (New York: Alfred A. Knopf,
} 1986), 9-10.

${ }^{3}$ Ibid., 135.

${ }^{4}$ Philip Caputo, A Rumor of War, New York: Holt, Rinehart and Winston, 1977; Owl Books, 1996), 27.

${ }^{5}$ Ibid., 28. 
It is no coincidence that the platoons of all three of these memoirists were composed predominantly of economically and educationally disadvantaged men in their late teens or early twenties. Christian G. Appy argues in his important book, WorkingClass War: American Combat Soldiers and Vietnam, that most enlisted men who served in Vietnam came from poor or working-class backgrounds; were, on average, nineteen years old when they went to war; and had not gone to college. Most middle and upperclass young men were able to skip (or at least, postpone) military service in the Vietnam era, primarily through college deferments. Less privileged men generally could not afford higher education in this era, which left them at the mercy of their draft boards. Most disadvantaged men who turned eighteen during the war had only two real choices when it came to the draft: await the arrival of their draft notice, or submit to the inevitable and volunteer for military service. ${ }^{6}$

Over two million U.S. troops served in Vietnam during the war, but only a small percentage of them were actively involved in combat. Most GIs in Vietnam filled a myriad of noncombat roles that a large, modern military force requires to function, from mess-hall cook to intelligence analyst. There is debate over exactly how many American military personnel in Vietnam were combat soldiers, but the ratio of support troops to combat troops was, according to Appy, "at least 5 to 1 ," and possibly even higher. ${ }^{7}$ It is significant, then, that Puller, Broyles, and Caputo were all in charge of infantry platoons. These troops were the Marine Corps and Army "grunts" that carried out the bulk of

\footnotetext{
${ }^{6}$ Christian G. Appy, Working-Class War: American Combat Soldiers and Vietnam (Chapel Hill, NC: The University of North Carolina Press, 1993), 25-35, 44-46.

${ }^{7}$ Ibid., 167. See also Lawrence M. Baskir and William A. Strauss, Chance and Circumstance: The Draft, the War and the Vietnam Generation (New York: Alfred A. Knopf, 1978; Vintage Books, 1978), 5153.
} 
American ground combat operations during the war. ${ }^{8}$ Due to military procedures of the period, recruits with poor educational backgrounds were frequently assigned to the infantry. ${ }^{9}$ Since education level was a strong indicator of social-class level in the Vietnam era, these policies ensured that poor and working-class troops would fill the infantry's ranks. ${ }^{10}$

The enlisted men commanded by the three memoirists mentioned above represented average combat soldiers. These three authors, like most of those who produced accounts of their experiences in the war, were combat veterans; but they, also like most memoirists, did not represent ordinary combat troops. The majority of veteran memoirists were middle-class college graduates and, on average, twenty-seven-years old when they served in Southeast Asia. While most memoirists served as officers, nearly 90 percent of the troops in Vietnam were enlisted men. ${ }^{11}$ Although underprivileged men of all races and ethnicities were more likely to see combat than their more fortunate counterparts, infantry units were disproportionately staffed by African Americans and other nonwhites. ${ }^{12}$ The fact that the fighting force the U.S. sent to Southeast Asia was heavily populated by the least fortunate segments of its population is a significant facet of Vietnam War history. It is worrisome that people may not have been exposed to this important historical reality if they read books written by veterans who were primarily middle-class, college educated, and white.

${ }^{8}$ Baskir and Strauss, Chance and Circumstance, 54-55.

${ }^{9}$ Ibid., 52-59.

${ }^{10}$ Appy, Working-Class War, 25-26, 45-46.

${ }^{11}$ Ibid., 24. "Officers comprised 11 percent of the total number of men in Vietnam."

${ }^{12}$ James Westheider, Fighting on Two Fronts: African Americans and the Vietnam War (New York: New York University Press, 1997), 11-14. 
Despite the importance of the memoirists' socio-economic characteristics, however, this topic has garnered little attention from scholars or popular writers. A handful of literary critics and scholars have written about the demographics of Vietnam veteran authors, but most devote no more than a few sentences or paragraphs to the issue, and they usually focus on only one significant category, such as age, race, or rank. ${ }^{13}$ More importantly, only a few of these writers speculate on how a veteran-author's background might influence how the war is portrayed in his or her book, and how, in turn, that portrayal might have affected readers' conceptions of Vietnam War history. ${ }^{14}$ Historians, in keeping with their tendency to use veteran memoirs only as primary

${ }^{13}$ Reviewers of veteran memoirs occasionally mentioned the socio-economic characteristics of memoirists. C.D.B. Bryan, for instance, speculated in his 1976 The New York Times review of Ron Kovic's Born on the Fourth of July that few Vietnam veterans had produced memoirs and war novels by that point in time because those most "capable of writing the Vietnam-era's equivalent to a Naked and the Dead ... were also capable of avoiding the draft." C.D.B. Bryan, "Growing Up the Hard Way" The New York Times, 15 August 1976. Bryan and other reviewers, however, never expanded their commentary on this topic beyond a few sentences.

A pair of literary scholars, Merritt Clifton and Philip K. Jason, wrote somewhat more about veteran author demographics. Clifton, the editor of Those Who Were There, a 1984 bibliography of published firsthand accounts of the war, theorized that the existence of so many capable Vietnam veteran writers was explained by the relatively high recruiting standards of the Marine Corps, which "drew heavily from those achieving a medium level of education: at least a high school diploma, perhaps a year of college." Merritt Clifton, Those Who Were There: Eyewitness Accounts of the War in Southeast Asia, 1956-1975, \& Aftermath (Paradise, CA: Dustbooks, 1984), vii-viii. Jason speculated that so many Vietnam veterans "had the equipment to turn their experiences into literary documents" because of the postWorld War II expansion of educational opportunities in the United States. Philip K. Jason, ed., Fourteen Landing Zones: Approaches to Vietnam War Literature (lowa City, IA: University of lowa Press, 1991), x. These few statements, however, were basically all either writer said about this topic.

${ }^{14}$ The few literary scholars wrote anything about the possible effects of veteran author demographics on public memory of the war all focus on only one demographic characteristic. In Late Thoughts on an Old War, Philip Beidler wrote about how the distinctive backgrounds of the veteran authors of cheap paperback titles about the war, which he calls "Vietpulp," affected how the war was portrayed in such books. Philip D. Beidler, Late Thoughts on an Old War: The Legacy of Vietnam (Athens, GA: University of Georgia Press, 2004), 123-138. Two scholars, Herman Beavers and Perry Luckett, speculated on how the lack of African-American veteran memoirists and novelists affected how racial issues were portrayed in Vietnam War literature. Herman Beavers, "Contemporary Afro-American Studies and the Study of the Vietnam War," Vietnam Generation 1, no. 2 (1989), 6-13; Perry D. Luckett, "The Black Soldier in Vietnam War Literature and Film," War, Literature, and the Arts 1, no. 2 (1989-1990), 1-27. 
sources to be mined for information, have written virtually nothing about the backgrounds of veteran memoirists. ${ }^{15}$

This chapter analyzes the available demographic data of fifty-one authors of the fifty-five memoirs that serve as the basis of this dissertation. The authors' background information gleaned from the memoirs and other sources has been organized into eleven categories: year born, race, pre-military education level, method of induction into the armed forces, highest rank achieved while in Vietnam, method of acquiring officer commission, military branch, age upon arrival in Vietnam, number of years served in Vietnam, military occupational specialty (MOS) in Vietnam, and total number of years served in the military. Besides the data organized under these headings, other less quantifiable pieces of information, such as reasons for joining the military and socialclass level, are also factored into the analysis.

Examination of the compiled data indicates that the authors fall into three distinct rank-based groups. The first group consists of ten individuals who served in Vietnam as high-ranking officers: nine "field-grade" or "general-grade" commissioned officers, and one senior enlisted non-commissioned officer, or "NCO." These men were white career soldiers who joined the military well before the start of the war, went to Vietnam at the average age of thirty-eight, and served in the military for many years, sometimes decades, after the war. The second group consists of fifteen memoirists who were low-ranking enlisted men and junior NCOs in Vietnam. These authors' backgrounds, in many ways, represent those of ordinary combat soldiers: only one had a college degree; they served in

\footnotetext{
${ }^{15}$ The only example of a historian treating veteran memoirs as worthy of analysis, and not just as primary sources, was George Herring's review of seven memoirs and other nonfiction books about that war that appeared in the Journal of American History in 1986. George C. Herring, "Vietnam Remembered," Journal of American History 73, no. 1 (June 1986): 152-164.
} 
Vietnam at the average age of twenty, and none spent more than a few years in the military. Although nonwhites are underrepresented among veteran-memoirists no matter how they are divided up, four of the six nonwhite authors fell into this second cohort.

The third and largest group is composed of twenty-six veterans who went to war as low-ranking "junior" commissioned officers. These lieutenants and captains were only slightly older than the enlisted men they oversaw in Vietnam, but most other aspects of their backgrounds set them apart from enlisted grunts. Over half the authors in this group earned college degrees before entering the military, most appear to be from middle-class households, and all but two were white. Though not as career-minded as the senior officers in group one, nearly half of the authors who served as junior officers in Vietnam pursued military careers after their combat tours there ended.

Splitting up the memoirists into these groups does nothing to mitigate their overall dissimilarity to regular combat troops. In fact, it demonstrates that only fifteen of the fifty-one authors had backgrounds that closely resembled those of the soldiers who did most of the fighting and dying for the U.S. in Vietnam. Taking this approach, however, indicates that a majority of the memoirists were similar to regular combat troops with regard to one crucial category: type of Vietnam experience. Most senior U.S. officers, like the ten authors in group one, were personally and geographically distant from enlisted men in Vietnam. While American infantrymen searched for the Vietcong in the countryside, the generals and colonels who had ordered such patrols usually stayed in the rear. Junior officers in Vietnam lived, worked, fought, and died alongside the enlisted men under their command. ${ }^{16}$ This means that most of the fifty-one veteran-

\footnotetext{
${ }^{16}$ Ron Milam, Not a Gentleman's War: An Inside View of Junior Officers in the Vietnam War (Chapel Hill, NC: The University of North Carolina Press, 2009), 5-8.
} 
authored memoirs were written either by former low-ranking enlisted men or by junior officers who, whatever their social or educational backgrounds, shared the grunts' war experiences.

The possible effects of the memoirists' demographics on how the war is portrayed in their books are, therefore, both positive and negative. The great majority of the authors had dissimilar backgrounds from the average combat soldier, and because of this, readers may be misled about what types of Americans actually fought in Vietnam. Several memoirists mention that people unlike themselves, poor whites and minorities, fought in disproportionate numbers in Vietnam. But most do not. Consequently, the common story of the poor teenager from the inner-city ghetto or Appalachia who is drafted and becomes an infantryman because he cannot afford college is rare in these accounts. On the positive side, only a handful of memoirs were written by military elites whose war experiences differed greatly from those of typical combat troops. The rest of these books were written by either combat veterans who served as enlisted men, or more likely, by authors who fought alongside such men as low-ranking officers.

The government and military leaders who planned and managed America's long conflict in Vietnam were men in or around middle age, most of them members of the generation that grew up during the Great Depression and fought in World War II. In contrast, the great majority of the American soldiers who fought in Southeast Asia in the 1960's and 70's belonged to the generation born after World War II, the Baby Boom Generation. ${ }^{17}$ The birth year statistics for the memoirists as a group do not reflect this reality. The average birth year for the authors is 1941, and well over half were born

\footnotetext{
${ }^{17}$ Baskir and Strauss, Chance and Circumstance, 3.
} 
before 1945, the final year of World War II. These unrepresentative results mostly reflect the presence of the former senior officers among the fifty-one authors. The average birth year for the senior officers in group one was 1927, with most of their birth dates falling in the 1920's and 30's, except for General William C. Westmoreland, the onetime commander of all U.S. forces in Vietnam, who was born in 1914. Whereas most soldiers who served in Vietnam were born after the U.S. defeated Germany and Japan in 1945, all the former senior officers were alive during that conflict, and three actually fought in it. The average birth year for the enlisted men in group two was 1946, and only three were born before 1945, which corresponds to their status as generally average combat veterans. Although only eight of the twenty-six junior officers were true "Baby Boomers," most were only slightly older than the typical enlisted GI in Vietnam. Their average birth year was 1944.

More important than when a veteran was born is at what age he or she served in Vietnam, for one of the most notable characteristics of the conflict was that it was, in the words of one historian, a "teenage war." 18 The average age for an American soldier in Vietnam was nineteen, which is young compared to U.S. troops in World War II, who went off to war at an average age of twenty-six. ${ }^{19}$ Almost 44 percent of all U.S. servicemen killed in Southeast Asia were less than twenty-one years old when they died. ${ }^{20}$ Most of the authors of Vietnam War memoirs were not in this age range during their combat tours. Their average age in Vietnam was twenty-seven. This outcome was,

${ }^{18}$ Loren Baritz, Backfire: A History of How American Culture Led Us into Vietnam and Made Us Fight the Way We Did (New York: William Morrow, 1985), 276- 277.

${ }^{19}$ Appy, Working-Class War, 27.

20 "Record Counts by Age and Time of Death or Declaration of Death," Combat Area Casualties Current File (CACCF), National Archives and Records Administration, obtained from www.archives.gov. 
again, partly the result of the presence of the former senior officers in group one, who served in Vietnam at the average age of thirty-eight.

In contrast to the senior officers, the fifteen former enlisted men in group two basically reflected the age of the typical GI in Vietnam, for they went to war at the average age of twenty, six of them as teenagers. The average age of the former junior officers in Vietnam, twenty-four, was only slightly higher than their enlisted counterparts. This means that the great majority of memoirs were written by two groups of veterans who were both relatively young when they went to war. The age gap between enlisted men in their teens, and junior officers in their mid-twenties, however, was wider than it seems. Broyles, the former Marine Corps officer, argues that teenage soldiers, just out of high school, probably "away from home for the first time," and "impressionable, immature .. . [and] unformed by experience," were affected by the war differently than men only a few years older. ${ }^{21}$ Broyles' argument is supported by the experiences of veterans like Bruce Weigl, a memoirist who was forever scarred by his swift and jarring transition from naïve teenager to combat infantryman in Southeast Asia. ${ }^{22}$ There are no real counterparts to accounts like this in the memoirs of former junior officers who arrived in Vietnam in their mid-twenties.

The U.S. fighting force sent to Vietnam was not just youthful, but also economically disadvantaged. Appy estimates in Working-Class War that the "enlisted ranks in Vietnam were comprised of about 25 percent poor, 55 percent working class, and 20 percent middle class, with a statistically negligible number of wealthy." 23 This

\footnotetext{
${ }^{21}$ Broyles, Jr., Brothers in Arms, 136.

${ }^{22}$ Bruce Weigl, The Circle of Hahn: A Memoir (New York: Grove Press, 2000), 1-6.
} 
situation was largely the result of a draft system, dubbed "channeling" by the Selective Service, ${ }^{24}$ designed to steer draft-aged men "in directions that served the national interest." 25 The most common and significant manifestation of this system was the draft exemption given to college students, a policy designed to give "the next generation of doctors, scientists, and engineers" the chance to complete their educations. ${ }^{26}$ Since most low-income Americans could not afford college during the Vietnam era, middle and upper-class men were the primary beneficiaries of this policy. ${ }^{27}$ Men of more privileged backgrounds were also better equipped to take advantage of other means used to avoid the draft, such as obtaining phony medical exemptions or joining the National Guard. ${ }^{28}$ The benefits of class and education did not disappear when recruits, draftees and volunteers alike, entered the armed forces. After basic training, Pentagon computers assigned recruits to occupational specialties according to their education levels, how they performed on intelligence and aptitude tests, and other relevant criteria. ${ }^{29}$ Consequently, personnel "with above-average aptitude or ability were . . . assigned special functions, often far from the combat zone."30 Well-educated soldiers were also personally "skimmed out of the manpower pool by officers who wanted reliable clerks, messengers,

${ }^{23}$ Appy, Working-Class War, 27.

${ }^{24}$ For a detailed explanation of channeling see Baskir and Strauss, Chance and Circumstance, 1428.

${ }^{25}$ Ibid., 17.

${ }^{26}$ Ibid., 15.

${ }^{27}$ Appy, Working-Class War, 25-26, 45-46.

${ }^{28}$ Baskir and Strauss, Chance and Circumstance, 29-51.

${ }^{29}$ Ibid., 52-56. See also Westheider, Fighting on Two Fronts, 37-39.

30 lbid., 52. 
servants, or other helpers." "31 Recruits “of lesser talents” were regularly slated for infantry training, which increased the likelihood of seeing combat in Vietnam. ${ }^{32}$ This system was unintentionally weighted against low-income men because they were generally less educated than their more fortunate counterparts. Because of lower-class recruits' comparatively substandard educations, many fared poorly on the Armed Forces Qualification Test (AFQT), the intelligence test that partly determined a soldier's MOS. ${ }^{33}$ Since relatively few soldiers from underprivileged backgrounds had gone to college, fewer GIs from poor families were assigned to technical and clerical positions ordinarily staffed by college graduates.

What, then, was the class makeup of the memoirists? Considering the prohibitive expense of higher education during the Vietnam era, education level is a good way to answer this question. ${ }^{34}$ The educational levels of the troops in Vietnam were: 18 percent high school drop-outs, 59 percent high school graduates, 15 percent attended college from one to three years, and 8 percent attended college four or more years. ${ }^{35}$ The overall education statistics for the fifty-one memoirists are glaringly unrepresentative of this reality: five were high-school drop-outs, ten were high-school graduates, eleven attended college but did not graduate, and twenty-three, almost half, were college graduates. ${ }^{36}$ This overrepresentation of college graduates is a direct result of the preponderance of

${ }^{31}$ Ibid., 57.

32 Ibid., 52-56.

${ }^{33}$ Westheider, Fighting on Two Fronts, 37-39.

${ }^{34}$ Appy, Working-Class War, 25.

35 John Helmer, Bringing the War Home: The American Soldier in the Vietnam and After (New York: The Free Press, 1974), 303.

${ }^{36}$ The education levels of two memoirists could not be determined. 
officers in the study, since a college degree was generally required to obtain a commission. Only one of the former enlisted men graduated from college before joining the military.

Over half of the former officers in the study had college degrees before entering the military, indicating that many of them hailed from backgrounds significantly more privileged than those of ordinary combat troops. Only a few of these individuals, however, graduated from elite civilian universities, the Army's U.S. Military Academy ("West Point"), or its Navy counterpart, the U.S. Naval Academy. Closer examination into the backgrounds of the college graduates confirms that most of them were hardly the sons and daughters of the upper class. Caputo points out that his family had "just recently struggled out of the working class," and that his degree came from "a parochial commuter-college."37 Colin Powell, future Chairman of the Joint Chiefs and Secretary of State, grew up in the working-class neighborhood of Hunts Point in the Bronx, New York, and graduated from City College of New York (CCNY). ${ }^{38}$ Everett Alvarez, a former fighter pilot and prisoner of war, was only able to afford to go to college because his mother contributed wages she earned working in a produce packing plant to his tuition fund. ${ }^{39}$

Besides the few authors who attended military academies, all the former officers who graduated from college before entering the military obtained their commissions through completion of either the Reserve Officer Training Corps (ROTC) program or Officer Candidate School (OCS). ROTC cadets undertook officer training while still in

\footnotetext{
${ }^{37}$ Caputo, A Rumor of War, 221.

${ }^{38}$ Colin Powell, My American Journey (New York, Random House, 1995), 25.

${ }^{39}$ Everett Alavarez, Jr. and Anthony S. Pitch, Chained Eagle (New York: Donald I. Fine, 1989), 55.
} 
college and received their commissions upon graduation. Those who took the other route enlisted in the military after graduation, then began OCS, and were rewarded commissions upon successful completion of the program. There were other ways to become an officer that did not require a college degree, and thirteen of the former officers used one of these methods. The most common means used by someone without a college degree to obtain a commission was to complete OCS, because though college graduates were preferred, OCS was open to enlisted men who met the necessary qualifications. ${ }^{40}$ Six authors, ranging in education level from less than four years of high school to a few years of college, became officers through this method. The nine other former officers without pre-military college degrees obtained commissions through other less common means, including graduating from an "aviation cadet program," earning a "field commission," or joining the Army Nurse Corps.

Since West Point produced relatively few officers, and because participation in ROTC programs plunged as the war progressed, about fifty percent of all the junior Army officers who served in Vietnam were OCS graduates. ${ }^{41}$ With so many non-collegeeducated men and women obtaining commissions through OCS or other means, it is likely that the officer corps in Vietnam was composed of a substantial number of people from poor or working-class backgrounds. ${ }^{42}$ Several of the thirteen former officers without college degrees validate this assumption. Tobias Wolff was raised by a single mother, a secretary who worked nights as a waitress. When he joined the Army in the mid-1960's, he was a teenage high school drop-out. After basic training, however, Wolff

\footnotetext{
${ }^{40}$ Milam, Not a Gentleman's War, 18-21.

${ }^{41}$ Ibid., 26.

${ }^{42}$ Appy, Working-Class War, 24.
} 
went on to complete Airborne school, Special Forces training, and finally, OCS. ${ }^{43}$

Another memoirist, Frederick Downs, grew up on a farm in Indiana, and only completed a couple years of college before he enlisted in the Army; but he also made it through OCS and became an officer. ${ }^{44}$

Although the great majority of authors were not from truly wealthy backgrounds, most nevertheless apparently came from the middle class. The disproportionately large number of memoirists with college degrees is one indication of this, ${ }^{45}$ but many veterans also provide other clues in descriptions of their pre-Vietnam lives. Authors of Vietnam War memoirs regularly describe growing up in comfortable middle-class surroundings, often in the suburbs, and usually with at least one parent holding a secure, well-paying job. One author was the son of a man who worked in a "prestigious, major, advertising firm"; ${ }^{46}$ another had a father who sold real-estate for a living, ${ }^{47}$ and still another describes her childhood as "middle-class suburban." 48 Even the relatively few memoirists who were raised in working-class households sometimes describe their childhoods as stable and carefree. Ron Kovic, for instance, grew up in a working-class suburb, and his father worked in a supermarket. Kovic's memoir nevertheless portrays his pre-war life as an

${ }^{43}$ Tobias Wolff, In Pharoah's Army: Memories of the Lost War (New York: Alfred A. Knopf, 1994), 42-58.

${ }^{44}$ Frederick Downs, The Killing Zone: My Life in the Vietnam War (New York: WW Norton \& Company, 1978), 15, 29, 230.

${ }^{45}$ Appy, Working-Class War, 25-26, 45-46.

${ }^{46}$ Joseph W. Callaway, Jr., Mekong First Light (New York: Presdio Press/Ballantine Books, 2004), 19.

${ }^{47}$ Robert Mason, Chickenhawk (New York: Viking, 1983; Penguin, 2005), 21.

${ }^{48}$ Lynda Van Devanter with Christopher Morgan, Home Before Morning: The Story of an Army Nurse in Vietnam (New York: Beaufort Books, 1983), 28. 
idyllic world of baseball games, John-Wayne movies, and parades. ${ }^{49}$ Appy argues that the pre-war lives of the low-income men who went to Vietnam were typically not so carefree, ${ }^{50}$ but were instead "full of very adult concerns: money, jobs, and survival."

Class was the most important factor in determining who saw combat in Vietnam, but race also came into play. Like whites in the same economic circumstances, impoverished African Americans were vulnerable to military and draft policies that favored better-educated groups. The best evidence that the "channeling" system took a disproportionate toll on African Americans comes in the form of casualty statistics. In the earliest phases of the war, the number of African Americans killed in Vietnam was greatly out of proportion to their overall share of the U.S. population. Black casualty rates eventually fell to levels commensurate with African-American population percentages, but this did not happen until relatively late in the war. ${ }^{52}$ Although scant information is available about other nonwhite groups that fought in the war, it is likely that some, such as Puerto Ricans and Mexican Americans, also shouldered more than their fair share of the fighting in Vietnam. ${ }^{53}$ Considering the inordinate sacrifices made by these groups, it is noteworthy that only six of the fifty-one most prominent memoirists

${ }^{49}$ Ron Kovic, Born on the Fourth of July (New York: McGraw Hill, 1976; reprint, New York: Akashic, 2005), 57-74.

${ }^{50}$ Appy, Working-Class War, 80-82.

51 lbid., 82.

${ }^{52}$ Westheider, Fighting on Two Fronts, 11-14.

${ }^{53}$ The author of a 1971 study concluded that "Mexican American military personnel have a higher death rate in Vietnam than all other servicemen" because a high percentage of casualties from southwestern states had Spanish surnames. Ralph Guzman, "Mexican American Casualties in Vietnam," La Raza 1, no. 1, 1971, 12). 
were nonwhites: five African Americans and one Mexican American. ${ }^{54}$ This dearth of minority authors was probably due to the overrepresentation of officers and college graduates in the pool of eligible candidates. During the war years, only a small percentage of the officer corps was nonwhite, and prior to the 1970s, the number of people of color who had graduated from college lagged far behind that of the white population. $^{55}$

The draft struck fear into the hearts of many young men during the war, and the statistics show that their apprehensions were not unfounded. Draftees accounted for about a third of all the troops who served in Vietnam. Between 1965 and 1970, the percentage of American soldiers killed in Southeast Asia who were draftees steadily rose from 16 to 43 percent. In the U.S. Army, the military branch in which most draftees served, the yearly death rates for draftees were even higher, topping out at 62 percent in 1969. ${ }^{56}$ These figures do not tell the whole story, however, since almost half of the respondents to a 1968 Defense Department survey of enlisted volunteers said that the "most important reason" for their enlistment was to avoid the draft. ${ }^{57}$ Many young men, preferring to have some degree of control over their fates, or believing that volunteering lessened the chances of going to Vietnam, enlisted rather than waiting to be drafted. This

\footnotetext{
${ }^{54}$ Several other books written by nonwhite veterans were also published, but because they received comparatively little recognition, they were not included in the primary group of memoirs. These books, however, are analyzed in Chapter 4, along with other less prominent personal narratives produced by minority veterans.

${ }^{55}$ Westheider, Fighting on Two Fronts, 120-123.

${ }^{56}$ Appy, Working-Class War, 28-29.

${ }^{57}$ Helmer, Bringing the War Home, 34.
} 
was true not just for enlisted men, but also for officers; 60 percent of all the officers who volunteered in 1968 signed up because of the draft. ${ }^{58}$

With these "draft-motivated" volunteers comprising another third of all the troops who served in Vietnam, the remaining third was composed of "true volunteers," those whose reasons for enlistment did not involve the draft. ${ }^{59}$ The phrase "true volunteer" is misleading, however, for the great majority of the men who fell into this category did not enlist to help the South Vietnamese fight Communist aggression, the American government's stated reason for military involvement in Vietnam. Only 6 percent of the respondents to the Department of Defense survey said they signed up to "serve [their] country," with the rest (besides the draft-motivated respondents) citing sundry other reasons, including "to become more mature and self-reliant," "to leave some personal problems behind me," and "to learn a trade."60 John Helmer, as part of his study of Vietnam veterans, Bringing the War Home, asked true volunteers for the primary reason they enlisted, and their number one response was "nothing else to do."61

Veteran-authors differed significantly from the average combat GI when it came to how they joined the military, for only seven out of fifty-one were draftees. This, again, is mostly a consequence of there being an inordinate number of officers in the study. Although it was technically possible for a draftee to become an officer, it was highly unlikely. As for why the authors joined the military, almost half signed up before the war had even started, so Vietnam played no part in their decision. Those who did join during

\footnotetext{
${ }^{58}$ Appy, Working-Class War, 29, 45-47.

${ }^{59}$ Ibid., 28.

${ }^{60}$ Helmer, Bringing the War Home, 34.

61 Ibid., 110.
} 
the war, however, were also dissimilar to regular combat troops because many cited intensely personal reasons for volunteering. A few signed up specifically to fight Communism, such as one author who was such a true believer that he wrote a pro-war editorial in his high school journalism class, and skipped college so he could fight for South Vietnam's freedom. ${ }^{62}$ Many more said they joined out of a general sense of patriotism, to prove their manhood, carry on family traditions, or to fulfill some other noble goal or desire. One author wrote that he volunteered for the Marine Corps in 1966 because "history was unfolding and [he] had an urge to be a part of it,"63 and another veteran told his parents he enlisted because he wanted to repay his country for all the freedoms it had given him. ${ }^{64}$

Several memoirists related that the draft factored into their decision to enlist, but most of these veterans also said that other more profound reasons also propelled them. One veteran indicated that he enlisted because a recruiter convinced him not to wait to be drafted. This young man also admitted to wanting to emulate his Korean War veteran uncle. ${ }^{65}$ Another said that the "draft board was closing in" at the time of his enlistment. He also claimed that he "burned for a new adventure" and was inspired to volunteer when a friend was killed in Vietnam. ${ }^{66}$

\footnotetext{
${ }^{62}$ W.D. Ehrhart, Vietnam-Perkasie: A Combat Marine Memoir (Jefferson, NC: McFarland, 1983; reprint, Amherst, MA: University of Massachusetts Press), 8-10.

${ }^{63}$ Michael Norman, These Good Men: Friendships Forged from War (New York: Crown Publshers, 1989), 76.

${ }^{64}$ Charles R. Anderson, Vietnam: The Other War (Novato, CA: Presidio Press, 1982), 52-53.

${ }^{65}$ Rod Kane, Veteran's Day: A Combat Odyssey (New York: Orion; Pocket Book, 1990), 1-6.

${ }^{66}$ Nathaniel Tripp, Father, Soldier, Son: Memoir of a Platoon Leader in Vietnam (South Royalton, Vermont: Steerforth Press, 1996), 22.
} 
Now that it is clear what types of Americans fought in Vietnam, what was combat like for these troops? The Vietnam conflict was famously a war without frontlines, so it was possible for any American in South Vietnam to fall victim to an enemy attack. The Vietcong, America's guerrilla adversaries, might ambush an infantry platoon in the jungle, but they could also lob mortar shells onto an airbase, plant explosives in a jeep parked outside a restaurant, or waylay a GI who had wandered into the wrong neighborhood. During the Tet Offensive of January 1968, Vietcong fighters attacked American forces in all areas of South Vietnam, including those stationed in Saigon, the relatively safe capital city. ${ }^{67}$ Memoirist Lynda Van Devanter, who served as a nurse in a U.S. Army hospital, was told, to her shock, on her first day in Vietnam that the Vietcong considered all Americans legitimate targets, including women. ${ }^{68}$

Even if all American troops in South Vietnam were at risk of being attacked, most were stationed in relatively safe and comfortable areas collectively called "the rear" by GIs. These support troops were derisively called "rear echelon mother fuckers" or "REMFs" by resentful combat troops. The minority of GIs who were consistently engaged in ground combat during the years of major U.S. military involvement in Vietnam, 1965 to 1973, were mostly Army troops and Marines. ${ }^{69}$ These were the infantrymen who carried out the "search and destroy operations" against America's enemies in the jungles, villages, and rice paddies of Vietnam. The type of war experienced by an infantryman depended somewhat on where he was stationed. Troops

\footnotetext{
${ }^{67}$ George C. Herring, America's Longest War: The United States and Vietnam, 1950-1975 (New York: John Wiley \& Sons, 1979), 183, 187.

${ }^{68}$ Van Devanter, Home Before, 78-79.

${ }^{69}$ Baskir and Strauss, Chance and Circumstance, 54-55.
} 
fighting uniformed North Vietnamese Army (NVA) soldiers in the sparsely populated northern regions of South Vietnam, for instance, had different experiences from those who fought against Vietcong guerrillas in the heavily populated Mekong River Delta area. $^{70}$ One thing that united these troops, though, was an unwillingness to stay in Vietnam beyond the required minimum one-year tour of duty. ${ }^{71}$

Unlike most GIs in Vietnam, most memoirists were combat soldiers. How do the authors' battlefield experiences compare to those of the ordinary infantryman? The importance of this information is highlighted by the massive post-1990 output of cheap paperback Vietnam War novels, biographies, and memoirs that focused on the exploits of elite combat outfits. If readers got all their information about the war from these types of books they might think that practically every soldier in Vietnam belonged to a group like the Army Special Forces ("Green Berets") or the Navy SEALs. Nothing could be further from the truth, however, since such soldiers comprised only a miniscule percentage of all American combat troops. ${ }^{72}$

A little under half of the fifty-one memoirists belonged to elite combat units like the Green Berets, or were involved in other atypical combat activities, such as the veteran who worked as an advisor to U.S. allies in a remote Vietnamese village. ${ }^{73}$ Nine of these atypical veterans were combat pilots who flew bombing missions over North Vietnam, and hence experienced the war far differently than the thousands of U.S. ground troops

\footnotetext{
${ }^{70}$ Herring, America's Longest War, 151-156.

${ }^{71}$ Appy, Working-Class War, 235-237. The standard Vietnam tour for Army personnel was twelve months, but Marines were required to serve at least thirteen.

72 Beidler, Late Thoughts, 123-138.

73 David Donovan, Once a Warrior King: Memories of an Officer in Vietnam (New York: McGrawHill, 1985), vii, 32-36.
} 
who fought in the South. One of these pilots, Arizona senator John McCain, notes the difference between air combat, which was "fought in short, violent bursts," and the experiences of infantrymen who "slog[ged] through awful conditions and danger for months on end."74 McCain and the other ten pilot-memoirists were also members of the tiny minority of American servicemen who were held as prisoners of war in Vietnam. ${ }^{75}$ The experiences of these former POWs were harrowing and nightmarish, but they nevertheless bore little resemblance to the ordeals faced by the average combat soldier.

On the other hand, about half of the authors in the study fought as Army or Marine Corps infantrymen, most of whom served only one tour in Vietnam. Crucially, this group was composed exclusively of either low-ranking enlisted men or junior officers. While field and general-grade officers spent much of their time in the rear, with access to "air conditioned billets with movie theaters, swimming pools, and officer's clubs, ${ }^{, 76}$ junior officers served alongside their men, and had the high casualty rates to prove it. ${ }^{77}$ Two authors who fought as junior officers in Vietnam, Downs and Puller, Jr., sustained major wounds while on patrol with their platoons. Downs' arm was blown off when he stepped on a "Bouncing Betty" landmine, ${ }^{78}$ and Puller lost both legs when he similarly triggered a booby-trapped artillery shell that had been buried by the Vietcong. ${ }^{79}$

${ }^{74}$ John McCain, Faith of My Fathers (New York: Random House, 1999), 180.

${ }^{75}$ Craig Howes, Voices of the Vietnam P.O.W.s: Witnesses to their Fight (New York: Oxford University Press, 1993), 4. An estimated 629 U.S. military personnel were held prisoner by enemy forces during the Vietnam War.

\footnotetext{
${ }^{76}$ Milam, Not a Gentleman's War, 5.

${ }^{77}$ Ibid., 6-8.

${ }^{78}$ Downs, The Killing Zone, 231-237.
} 
In Crisis in Command: Mismanagement in the Army, Richard A. Gabriel and Paul L. Savage argued that officers "must be perceived as willing to share the risks and sacrifices of battle" to be effective leaders. ${ }^{80}$ In their opinion, the senior officers in Vietnam utterly failed to meet this standard ${ }^{81}$ but the experiences of Puller and Downs show that the same cannot be said of junior officers.

The junior-officer memoirists universally say that they developed great affection for their enlisted men, and that these troops were not just their subordinates, but also their friends and "brothers." Caputo, for instance, reveals in A Rumor of War that the camaraderie that developed in his platoon was more profound than romantic love, and that "the sentiment of belonging to each other, was the one decent thing [they] found in a conflict otherwise notable for its monstrosities." ${ }^{\$ 2}$ Such close relationships formed between junior officers and enlisted men because they experienced the same battlefield experiences.

Just as important as what memoirists did in Vietnam is how long they served in the military, because there are major differences between the points of view of short-term soldiers and professional, career servicemen. Enlisted men and junior officers who stay in the armed forces for only a short amount of time are citizen soldiers who put their normal lives on hold while they serve their country. Despite the training and indoctrination necessary to transform a civilian into a capable soldier, the non-

\footnotetext{
${ }^{79}$ Puller, Fortunate Son, 157-161.

${ }^{80}$ Richard A. Gabriel and Paul L. Savage, Crisis in Command: Mismanagement in the Army (New York: Hill and Wang, 1978), 55.

${ }^{81}$ Ibid., 11-17, 65-66.

${ }^{82}$ Caputo, A Rumor of War, xvii.
} 
professional retains a civilian outlook on life. ${ }^{83}$ The professional soldier, conversely, has chosen to become, as Samuel P. Huntington explained in The Soldier and the State, a highly trained specialist in "the management of violence." 84 In many ways, military professionals are like professionals in civilian fields, but warfare is their focus. They are figuratively and literally set apart from the civilian world. Military professionals follow particular codes of honor and traditions, usually live and work only with other soldiers, and often see their profession as a "calling" or a "special mission.",85

Someone who volunteered for military service during the Vietnam era, enlisted men and officers alike, generally signed up for a two-to-four-year commitment, while draftees were required to serve at least two years. Most enlisted men did not choose to stay in the military beyond their first enlistment, ${ }^{86}$ which is no surprise, since the enlisted ranks were filled with draftees and draft-motivated volunteers at that time. An unwillingness to become professional soldiers was not restricted to enlisted men, but was shared by many junior officers as well. The great majority of Vietnam-era officers acquired their commissions through ROTC or OCS. During the war, Army officers who obtained their commissions through these two methods were nearly as unwilling to pursue military careers as enlisted men. From 1966 to 1970, the number of Army OCS

\footnotetext{
${ }^{83}$ Samuel P. Huntington, The Soldier and the State: The Theory and Politics of Civil-Military Relations (Cambridge, MA: The Belknap Press of Harvard University Press, 1964), 17.

${ }^{84}$ Ibid., 13.

${ }^{85}$ Morris Janowitz, The Professional Soldier: A Social and Political Portrait (Glencoe, IL: The Free Press, 1960), 80, 104-107, 137, 175-178, 218-219.

${ }^{86}$ Appy, Working-Class War, 49, 235-237. The Marine Corps was the only service branch that offered a two year enlistment option to recruits during the Vietnam era.
} 
officers who stayed on beyond their initial years of obligated service fell from 56 to 22 percent, and in 1970, only 11 percent of ROTC officers signed up for additional years. ${ }^{87}$

As usual, the fifteen memoirists who were low-ranking enlisted men in Vietnam basically represented the characteristics of the average GI, for none of them served any longer than four years in the military. The former senior officers in group one were all professional, career soldiers who joined the military well before the war started, and in most cases, continued their military careers after the war ended. Eleven (43 percent) of the twenty-six junior-officer memoirists stayed in the military after their tours in Vietnam. Taken as a whole, the memoirists consist of thirty veterans who were shortterm, non-professional soldiers and twenty-one who were career officers. This proportion of career soldiers is high considering that most enlisted men returned to civilian life shortly after their combat tours. Non-professionals were nevertheless in the majority. Moreover, half of these professional soldiers served as junior officers in Vietnam. These veterans, no matter how long their careers lasted after the war, were low-ranking officers in Vietnam who shared the same dangers and hardships as the enlisted men with whom they served.

A publishing company executive quoted in a Washington Post review of Rod Kane's 1990 memoir, Veteran's Day, asserted that Kane's book was important because it "filled a void that was societal as much as literary":

${ }^{87}$ Gabriel and Savage, Crisis in Command, 131. ROTC and OCS officers were always less likely to pursue military careers than U.S. Military Academy graduates, but even the number of West Pointers who served longer than the required minimum years of service dropped from almost 100 percent at the beginning of the war to 72 percent by its conclusion. 
It's a curious thing that many of the Vietnam books have been written by [veterans] who had lots of education and came from relatively sophisticated backgrounds, guys who had been to college and were officers. Rod Kane really represents the disenfranchised, the people who came out of the high schools, the drifters, the kids who had no one to speak for them. They were the ones who paid the price, they were blown to pieces. ${ }^{88}$

This assessment was completely accurate; the fifty-one most prominent Vietnamveteran memoirists had, as a whole, strikingly dissimilar backgrounds from the average American combat soldier. Whereas the typical combat infantryman was a teenage enlisted man with a high school education, the average veteran-author was a collegeeducated officer who served in Vietnam in his mid-twenties. Most of the GIs who went to Vietnam came from poor and working-class backgrounds and were likely either draftees or draft-motivated volunteers. Most memoirists grew up in middle-class households and volunteered for the military, often for idealistic reasons. Finally, although combat infantry units in Vietnam were disproportionally composed of African Americans and other minorities, all but six memoirists were white.

The unsettling fact that the fighting force sent to Vietnam was largely composed of the nation's poorest citizens is one of the most important aspects of the war. It is unfortunate, then, that this facet of the conflict's history is largely absent from the most popular veterans' memoirs. The authors of these narratives had uncommonly privileged backgrounds, and most did not mention that their pre-Vietnam lives were any different than those of average combat soldiers. This hole in the depiction of the war is partially compensated for by the existence of several popular oral histories that feature numerous

\footnotetext{
${ }^{88}$ Elizabeth Kastor, “The Combat Bachelor's War Within; Rod Kane's 'Veteran's Day,' Transcript of a 20-Year Obsession with Vietnam," The Washington Post, 19 April 1990, E1.
} 
interviews with apparently ordinary combat veterans, but because these titles are small in number compared to veteran memoirs, their influence has been limited. ${ }^{89}$

Although the backgrounds of the memoirists were different from average combat troops in many respects, the two groups were similar in one crucial aspect: wartime experiences. Most memoirists were either junior officers or enlisted men who spent a year in Vietnam and then returned to civilian life. About half of the authors were former infantrymen who took part in conventional combat operations, and because most were of low rank while in Vietnam, they were actively involved in combat. The publisher was correct that most memoirists came from exceptional backgrounds, but the majority, former junior officers and enlisted men alike, nevertheless "paid the price" and risked getting "blown to pieces."

${ }^{89}$ It is difficult to make a quantified analysis of the demographics of the veterans included in most oral history compilations, but many of the veterans featured in these books seem to have served in regular Army and Marine Corps units, and were from poor and working-class backgrounds. One of these books, Bloods: An Oral History of the Vietnam War by Black Veterans, was exclusively devoted to the accounts of African-American veterans. Wallace Terry, Bloods: An Oral History of the Vietnam War by Black Veterans (New York: Random House, 1984). 


\section{CHAPTER THREE}

\section{COMBAT CONDTIONS AND THE VIETNAMESE PEOPLE}

Of the hundreds of memoirs written by American veterans of the Vietnam War, And a Hard Rain Fell: A GI's True Story of the War in Vietnam, by John Ketwig, is perhaps the most bitter, unromantic, and depressing. As he approached draft age, Ketwig developed an apolitical, almost instinctual abhorrence of the growing war in Southeast Asia; it was only because of the looming draft and a lack of options that he enlisted in the Army in late 1966. A recruiter assured him that volunteering would keep him out of Vietnam, but he was shipped off to Southeast Asia not long after basic training anyway. Ketwig worked as a mechanic on an Army base during his tour in Vietnam, but he had several combat experiences that left him with deep psychological scars. While driving a truck that was part of a convoy tasked with resupplying combat troops he was nearly killed when the vehicle in front of him was destroyed by a landmine. ${ }^{1}$ When Ketwig's convoy finally reached the battlefield, he was met with the nightmarish scene of thousands of dispirited GIs "kneeling in the mud, peering into the shadows and awaiting death." 2 The soldiers were under constant enemy harassment, and due to sniper fire, the

\footnotetext{
${ }^{1}$ John Ketwig, And a Hard Rain Fell: A G.I.'s True Story of the War in Vietnam (New York: Macmillian, 1985), 3-36, 45-47.

2 Ibid., 55.
} 
only way they could retrieve their slain comrades was to chain their corpses to the back of an armored vehicle and drag them out of the line of fire. ${ }^{3}$

For days after his stint with the convoy, Ketwig "shook," went into rages, and "shivered," haunted by the memory of the "string" of American bodies being dragged through the mud. ${ }^{4}$ The most psychologically damaging experience of Ketwig's tour, however, did not come on the battlefield, but at an encampment of U.S. Army Special Forces soldiers, the famous "Green Berets." He went to the camp hoping to barter for black-market goods, but when he got there the Green Berets and their Vietnamese allies were torturing a woman they suspected had played some part in the death of a comrade. Ketwig describes the torture and the woman's eventual murder in sickening detail, and recalls the crushing guilt he felt afterward at not having done something to stop it. ${ }^{5} \mathrm{He}$ even questioned at the time whether he would "ever be able to return to everyday life in" the U.S. after witnessing such a horrible episode. ${ }^{6}$

Ketwig openly denounces the war in And a Hard Rain Fell. In addition, the despairing tone of the book and its graphic descriptions of combat and Americancommitted atrocities amount to an implicit indictment of the war. Strangely, then, another reoccurring theme in the book is Ketwig's contempt for the war's greatest victims: Vietnamese civilians. Ketwig's hatred was based on his perception of the Vietnamese as greedy, untrustworthy, ungrateful, and contemptuous of Americans. He

\footnotetext{
3 Ibid., 57.

${ }^{4}$ Ibid., 57-60.

${ }^{5}$ Ibid., 70-72.

${ }^{6}$ Ibid., 72.
} 
disdainfully describes Vietnamese cities as dangerous trash-strewn centers of vice, ${ }^{7}$ and South Vietnam in general as "a society of murderers, thieves, carnival hucksters." was angry that civilians ungratefully showed open resentment of Americans, ${ }^{9}$ such as the children who pelted the U.S. Army bus in which he was riding with garbage, shouting "go home" and "fuck you, GI." 10 During Ketwig's last day in Vietnam his wallet was stolen and he saw, to his astonishment, an old woman openly selling a U.S. military rifle in the marketplace. ${ }^{11}$ After these events it suddenly became clear to him that "the Vietnamese people didn't care about our noble mission, and until they cared it was hopeless."

Though Ketwig's portrayal of his Vietnam experience may seem peculiar, it is actually typical. Veterans' narratives generally portray the important and interrelated topics of combat and the Vietnamese people in ways similar to those delineated above. Most memoirists describe combat in an unromantic manner, almost totally eschewing the glorification of war that is often present in popular culture treatment of the subject. In most memoirs, combat is depicted as terrifying and exhausting, and the wounds and deaths that are the product of combat are described in graphic detail. Veterans' accounts also generally offer an accurate depiction of aspects of combat that were specific to the Vietnam conflict, especially the great difficulty American forces experienced in their

\footnotetext{
${ }^{7}$ Ibid., 62-65.

${ }^{8}$ Ibid., 63.

9 Ibid., 76.

10 Ibid., 29.

11 Ibid., 138-142.

12 Ibid., 142.
} 
attempts to counter the Vietcong's unconventional tactics. Veterans often describe this struggle to fight an enemy who regularly used booby-traps, staged hit-and-run ambushes, and hid in tunnels, as futile, nonsensical, and above all, deeply frustrating.

It is also apparent in most narratives that civilians were an integral aspect of combat in Vietnam, for the war was fought among them. They were usually indistinguishable from the enemy; in fact, they very often were the enemy. This battlefield environment led to civilian casualties and atrocities committed against civilians, and these unfortunate realities of the war are included in veteran narratives as well. Memoirists report that a profound anti-Vietnamese racism existed among American troops; racial slurs such as "gook," "dink," and "slope" are frequent throughout their accounts. Racial hatred was clearly the driving force behind some of the most heinous atrocities chronicled by veterans, including the practice of keeping enemy body parts, chiefly ears and skulls, as souvenirs.

As is the case in And a Hard Rain Fell, most memoirs combine realistic depictions of combat with portrayals of Vietnamese civilians as universally covetous of American dollars, but ungrateful for American sacrifices. Such a depiction leads to the formation of an unlikely theme in veteran narratives: Vietnamese civilians as the victimizers of American troops. Sharing the role of victimizer with civilians in narratives are the soldiers of the Army of the Republic of Vietnam (ARVN), America's chief military ally in Vietnam. ${ }^{13}$ These troops are portrayed as lazy cowards who not only

\footnotetext{
${ }^{13}$ Many scholars and other commentators have argued that Vietnam veterans have been portrayed as victims in one way or another in American culture. In The Remasculinization of America: Gender and the Vietnam War, Susan Jeffords names numerous groups that have been portrayed as victimizers of U.S. troops in representations of the war, including Vietnamese civilians and ARVN soldiers. Susan Jeffords, The Remasculinization of America: Gender and the Vietnam War (Indianapolis, IN: Indiana University Press, 1989), 116-143.
} 
preferred that American GIs do all the fighting and dying in the war, but were also ungrateful for, and even disdainful of, the sacrifices made by U.S. soldiers on behalf of South Vietnam's freedom. Whether they are portrayed as victimizers or not, all Vietnamese, friends and enemies, civilians and combatants, usually appear in narratives only as one dimensional racist caricatures, or faceless, voiceless figures who essentially function as scenery.

Few veterans' memoirs decisively fall into the "anti-war" category, but their collective portrayal of combat, with its examples of atrocities, bewildering guerrilla enemies, and perfidious allies, nevertheless offers a profoundly negative view of America's war in Southeast Asia. Why, then, does this implicit indictment of the war exist alongside an unsympathetic, often contemptuous portrayal of Vietnamese civilians? The reason for the co-existence of these two seemingly incompatible themes is directly related to the fundamental weakness of personal narratives: limited and biased perspective. Veteran narratives offer a view of the war from the perspective of American soldiers, and because of this, these sources do provide much valuable information, especially about combat. High-level civilian and military planners in Washington and Southeast Asia devised the strategies used by American forces in Vietnam, but the troops on the ground who implemented those strategies witnessed the results firsthand.

Nevertheless, veterans' narratives, because they represent the experiences of only one specific group of people, are inherently limited in their perspective on the war. Narrow perspective is responsible for the veterans' scornful, one-dimensional, and often racist depictions of the Vietnamese. The average American soldier arrived in Vietnam with essentially no knowledge of that country's language, culture, or history. Most GIs 
also lacked a nuanced understanding of the conflict in which they fought, knowing only of their government's oversimplified and not entirely accurate depiction of the war as a battle between Communist aggression and the forces of democracy. Moreover, most American soldiers, largely due to communications problems, had no meaningful contact with Vietnamese people during their tours in Southeast Asia. It is not surprising, then, that few veterans knew the real reasons for Vietnamese actions they despised.

This chapter approaches the issue of how memoirists portrayed combat and the Vietnamese people by comparing these portrayals to what other sources, chiefly historical scholarship and the accounts of Vietnamese, say about the same topics. Using this approach shows that depictions of combat in veterans' narratives often correspond to how historians and other writers have depicted Vietnam War combat. The outside sources also provide the information, missing from veterans' memoirs, that explains the cultural, social, economic, and historical reasons for the attitudes and behaviors of South Vietnamese living during what they called the "American War." Vietnamese accounts illustrate the necessity of using varying perspectives to gain a truer understanding of a historical event.

Memoirists regularly explain that their conception of combat before going to Vietnam was largely based on the staged battles they had seen played out in war movies, especially those about World War II. Such films have often inspired the future soldiers and their boyhood friends to act out the exploits of John Wayne and other celluloid military heroes in the woods, backyards, and vacant lots of their hometowns. These veterans who cheered on Wayne's character Sergeant Stryker in the The Sands of Iwo 
Jima, ${ }^{14}$ and killed imaginary "Krauts and Japs" ${ }^{15}$ as boys, realized early in their combat tours that their childhoods had ill prepared them for the realities of warfare. Newcomers to Vietnam, known as "cherries" or "FNGs" (Fucking New Guys) to more seasoned soldiers, quickly learned that mimicking the flashy fighting techniques they saw in movies usually led not to glory, but to death or injury. One memoirist explained that the term "John Wayne" was a "flat-out insult" in Vietnam, used to refer to "hot-dog, hero wannabes" not smart enough to understand the foolishness of performing cinematic-style stunts in real-life combat. ${ }^{16}$ Memoirist Lewis Puller, Jr. wrote of a young, inexperienced Marine in his platoon who was immediately hit by Vietcong gunfire when he "suddenly stood up and began firing his rifle John Wayne fashion from the hip" during a firefight. ${ }^{17}$

Besides learning the uselessness of Hollywood combat techniques, veterans also discovered that their youths had not prepared them for the most gruesome and unavoidable aspects of warfare: battle wounds and the bodies of slain soldiers and civilians. Real battlefield deaths and injuries were far removed from scenes of soldiers who grimaced and fought on with blood-stained shirts after getting shot, or doomed men who let out a final yell or an inspiring slogan before they slumped to the ground and died. Philip Caputo observes in A Rumor of War that the devastating gunshot wounds suffered by a Vietcong soldier killed by U.S. troops were nothing like "the tidy holes as in the

${ }^{14}$ Ron Kovic, Born on the Fourth of July (New York: McGraw Hill, 1976; reprint, New York: Akashic, 2005), 64-65; Philip Caputo, A Rumor of War, New York: Holt, Rinehart and Winston, 1977; Owl Books, 1996), 6.

${ }^{15}$ W.D. Ehrhart, Vietnam-Perkasie: A Combat Marine Memoir (Jefferson, NC: McFarland, 1983; reprint, Amherst, MA: University of Massachusetts Press, 1995), 7-8.

${ }^{16}$ Larry Heinemann, Black Virgin Mountain: A Return to Vietnam (New York: Doubleday, 2005), 89.

${ }^{17}$ Lewis B. Puller, Jr., Fortunate Son (New York: Grove Weindenfeld, 1991), 114. 
movies." 18 Another memoirist soberly related that, "what happens to human beings in mechanized warfare has absolutely no poetic or theatrical possibilities."

After commenting on the falseness of movie war wounds, Caputo goes on to describe the dead Vietcong's injuries, noting that the corpse lay in "a crimson puddle in which floated bits of skin and white cartilage." 20 Two pages earlier he writes of another Vietcong body with "brains spilling out of the huge hole in its head like grey pudding from a cracked bowl." ${ }^{21}$ Hideously realistic descriptions of wounds and corpses such as these are not limited to A Rumor of War, but are one of the defining elements of Vietnam veteran memoirs. In stark contrast to the war movies veterans watched as children, their narratives are full of descriptions of battlefield gore that are graphic, disgusting, and often difficult to read. The purpose of this technique is clearly not exploitative, but is another symptom of memoirists" desire to "tell like it was" in their narratives; to do so necessitates authentic descriptions of even the most horrible aspects of warfare.

Using World War II (either in its film or real-life incarnations) as a basis for understanding warfare led GIs, not to mention some of their leaders, to hold other preconceptions about combat that did not apply to the war in Vietnam. World War II featured, for the most part, battles waged by conventional armies for control of territory. In contrast, the conflict in South Vietnam was a political revolution and civil war fought against the backdrop of the Cold War; and the adversaries of the United States in this war often employed guerrilla tactics. At different points during its long military involvement

\footnotetext{
${ }^{18}$ Caputo, A Rumor of War, 120.

${ }^{19}$ Charles R. Anderson, The Grunts (San Rafael, CA: Presidio Press, 1976), 145.

${ }^{20}$ Caputo, A Rumor of War, 120.

${ }^{21}$ Ibid., 118.
} 
in Vietnam, the United States tried to counter the unconventional tactics of its foes by implementing various "counterinsurgency" strategies. The most famous practitioners of this type of warfare were the Green Berets, the elite U.S. Army unit revived by President John F. Kennedy in the early 1960’s.

For most of the war, however, the United States forsook counterinsurgency tactics in favor of trying to draw its elusive enemies into fighting conventional, set-piece battles that the American military, with its vastly superior firepower, was sure to win. This approach was taken by General William Westmoreland, the commander of U.S. forces during the opening phases of major American military operations in Vietnam. ${ }^{22}$ Westmoreland devised a strategy in which U.S. patrols conducting "search and destroy" operations in the countryside "would ... locate the enemy and then call in artillery and airpower to eliminate him." 23 In theory, such operations would eventually drive "large enemy units ... from populated areas," giving U.S. troops the opportunity to secure and "pacify" these locales by rooting out remaining "local guerillas" and Vietcong political leaders. ${ }^{24}$ Coupled with these tactics was a "war of attrition" strategy that entailed using the massive resources of the American military to kill as many enemy troops as possible. $^{25}$

These tactics, however, usually failed to produce the desired results, and many memoirs feature stories that confirm this. Former infantrymen who took part in "search

${ }^{22}$ Marilyn B. Young, The Vietnam Wars, 1945-1990 (New York: HarperCollins, 1991), 74-77, 8284, 144-146, 162-166. For more on Westmoreland and the strategies he employed in Vietnam see his autobiography: William C. Westmoreland, A Soldier Reports (Garden City, NY: Doubleday, 1976).

${ }^{23}$ Ibid., 163.

${ }^{24}$ Ibid.

${ }^{25}$ George C. Herring, America's Longest War: The United States and Vietnam, 1950-1975 (New York: John Wiley \& Sons, 1979, 153-154. 
and destroy" patrols often describe these operations as bewildering, exhausting, and frustrating affairs. Some recall that that they would go for long stretches without enemy contact despite their constant searching, and when they did make contact it was usually because they were ambushed. These accounts apparently represent the experience of most U.S. troops. Studies show that U.S. small-unit patrols infrequently made contact with the enemy, ${ }^{26}$ and that when they did it was usually initiated by the Vietcong. ${ }^{27} \mathrm{~A}$ common theme in the description of these actions is the idea that no one, from privates to high-level officers, knew what they were doing, and that their actions were futile. One memoirist consistently uses words like "blunder," "idiocy," and "chaos" to describe the "search and destroy" operations in which he participated. ${ }^{28}$ Another author says his own unit's patrols went as follows: "we wander around, bumping into things. Things bump into us." 29

Another symbol of the futility and pointlessness of U.S. strategy in Vietnam included in memoirs was that American troops, no matter how many enemy soldiers they killed, did not take control of the territory for which they had fought. Unlike World War II and other conventional wars, the task of U.S. troops in Vietnam was not to seize territory, but to clear areas of enemy personnel and kill as many of them as possible. One former infantry lieutenant says that because American troops did not "hold" the land they struggled over, it “didn’t take long to figure out that [the Vietnam conflict] was a

\footnotetext{
${ }^{26}$ Young, The Vietnam Wars, 186-187.

${ }^{27}$ Alain Enthoven, Memorandum for Secretary of Defense, 4 May 1967, The Pentagon Papers, IV, 462, in John Helmer, Bringing the War Home: The American Soldier in the Vietnam and After (New York: The Free Press, 1974), 26.

${ }^{28}$ Anderson, The Grunts, 37, 79.

${ }^{29}$ Rod Kane, Veteran's Day: A Combat Odyssey (New York: Orion; Pocket Book, 1990), 27.
} 
hopeless war." ${ }^{30}$ Some veterans noted that the seeming hopelessness of this strategy was compounded by the fact that areas officially deemed pacified or cleared of enemy troops often did not live up to that designation. The most infamous manifestation of this phenomenon occurred with Operation Cedar Falls, a 1967 U.S. attempt to clear out a Vietcong enclave near Saigon dubbed the "Iron Triangle." American troops evacuated all the civilians in the Iron Triangle, destroyed all the villages contained within it, and supposedly cleared it of enemy fighters, but six months later the Vietcong was again operating there. ${ }^{31}$

Perhaps the best depiction of the pointlessness of American tactics is found in a chapter of Caputo's A Rumor of War called "Officer in Charge of the Dead." For part of Caputo's tour in Vietnam he was assigned to a job in "the rear" that put him in charge of tallying American and enemy casualties. ${ }^{32}$ This task put him right in the middle of the war of attrition, a war in which the performance of an American unit was evaluated "by the number of enemy soldiers it had killed (the body count) and the proportion between that number and the number of its own dead (the kill ratio). ${ }^{, 33}$ Caputo kept track of these statistics on a "scoreboard" that the commander of his battalion consulted in order to determine which companies were producing good results and which needed to increase their body counts. American units all over South Vietnam were pressured to increase their body counts, ${ }^{34}$ and so it is not surprising that, as Caputo noted, many GIs were less

\footnotetext{
${ }^{30}$ Nathaniel Tripp, Father, Soldier, Son: Memoir of a Platoon Leader in Vietnam (South Royalton, Vermont: Steerforth Press, 1996), 62.

${ }^{31}$ Young, Vietnam Wars, 173-175.

${ }^{32}$ Caputo, A Rumor of War, 153-208.

33 Ibid., 168.
} 
than scrupulous in their identification of enemy remains, going by the maxim: "If it's dead and Vietnamese, it's VC."35

While many aspects of combat in Vietnam are described as frustrating in memoirs, the Vietcong's use of booby traps, especially landmines, is depicted as the most frustrating of all. It was bad enough to fight an enemy who attacked and then fled before any revenge could be exacted, but it was even worse when casualties were inflicted by inanimate objects. The most vivid account of the demoralizing effect that booby traps could have on U.S. soldiers is found in Puller's memoir, Fortunate Son. Puller, who was later badly maimed when he stepped on a buried, booby-trapped artillery shell, describes the weeks before his wounding as a "living hell" in which his men were constantly being taken out by landmines. Besides the terror Puller and his platoon felt at wondering whether they might be killed or wounded by hidden explosives, their morale was also gradually eroded by the frustration of not being able to retaliate for such attacks. ${ }^{36}$ Puller and his men struggled to answer a question posed by a veteran in another narrative: "How do you fight back against a booby trap?"37

Though a cynical attitude predominates in memoirists' depictions of combat, a number of authors express pride in their service, and do not suggest that their tours were a waste of time, or that American efforts in Vietnam were all ridiculous or futile. Virtually no memoirs, however, even those that present a generally positive view of the

\footnotetext{
${ }^{34}$ Ibid., xix, 168.

${ }^{35}$ Caputo, A Rumor of War, xx.

${ }^{36}$ Puller, Fortunate Son, 97-98, 114-116, 145-157.

${ }^{37}$ Al Santoli, Everything We Had: An Oral History of the Vietnam War by Thirty-Three American Soldiers Who Fought It (New York: Random House, 1981; Ballantine, 1983), 50.
} 
war, depict their authors' tours as having achieved much of anything. The majority of veterans portray the months they spent in Vietnam as one long series of firefights interrupted by brief periods of rest and inactivity. Almost never is the impression given that the efforts of the authors or their comrades, including the deaths of scores of enemy troops, are somehow contributing to an ultimate victory. At the end of most memoirs in this survey the author leaves Vietnam, and the war continues on without him, as if nothing has changed at all since he arrived in the war zone a year earlier.

Added to this sense of low achievement is the admission of some veterans that they eventually gave up caring about who won or lost the war. One former officer says he purposely kept his platoon out of an area with a strong Vietcong presence in order to avoid enemy contact. ${ }^{38}$ Such examples of "combat avoidance" reportedly occurred throughout the war, but were more common in the latter years of the conflict. ${ }^{39}$ Between 1965 and 1969, Matthew Brennan, author of the memoir Brennan's War, served three tours in Vietnam. The war seemed so hopeless by Brennan's final tour that he decided his only mission would be to make sure he and his men made it home alive. ${ }^{40}$ Unlike Brennan, most American troops did not serve in Vietnam longer than the required yearlong tour; but like him, many decided at some point that their sole duty was not to defeat the enemy, but to avoid death and injury long enough to make it back to the United States. $^{41}$

\footnotetext{
${ }^{38}$ Tripp, Father, Soldier, Son, 15-16.

${ }^{39}$ Christian G. Appy, Working-Class War: American Combat Soldiers and Vietnam (Chapel Hill, NC: The University of North Carolina Press, 1993), 222, 243-245.

${ }^{40}$ Matthew Brennan, Brennan's War: Vietnam 1965-69 (Novato, CA: Presidio Press, 1985), 211.

${ }^{41}$ Appy, Working-Class War, 243-245.
} 
A hallmark of guerrilla warfare is that it is fought amongst the people, and for this reason, civilians are inevitably caught in the crossfire and become unintentional casualties. The exact number of civilians killed in Vietnam is disputed and probably unknowable, but in 1975 the U.S. Senate "subcommittee on refugees" estimated that approximately “430, 000 South Vietnamese civilians were killed between 1965 and 1974 and more than 1 million were wounded." ${ }^{42}$ The Senate's estimate for civilian deaths is probably too low because it does not account for the unknown thousands of slain Vietnamese civilians who were erroneously added to the U.S. military's enemy body count. ${ }^{43}$ Due mostly to their "heavy reliance on firepower in and near populated areas," as much as 80 percent of the civilian casualties in South Vietnam were caused by U.S. and allied forces, rather than their foes. ${ }^{44}$ Though the bombing of North Vietnam has received more attention, U.S. aircraft also dropped millions of tons of explosives on South Vietnam. It is likely that a high percentage of Southern civilians killed in the conflict were caught in these air raids. ${ }^{45}$

Accounts of civilian casualties are common in veterans' narratives, but not in the form of deaths caused by American air or artillery bombardments. Instead, the most common civilian casualties recounted by veterans are those that were inflicted by specific American ground units, even individual soldiers. In such cases the memoirist knew who was directly responsible for the accidental killing of a civilian, often saw it take place, and in a few instances, is among those responsible. Such episodes are invariably

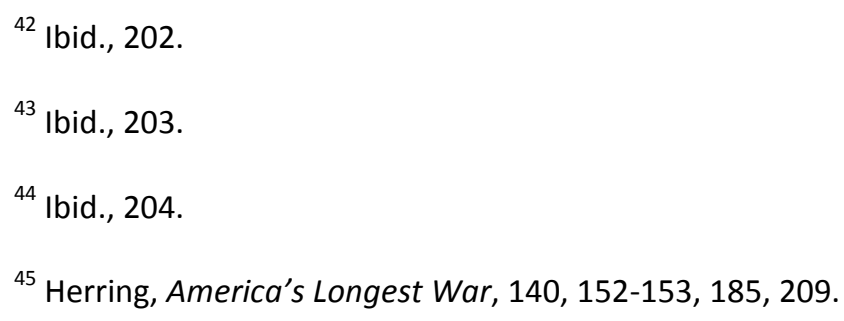


described as moments of profound horror and grief for the Americans at fault, especially when women and children were the victims. Brennan writes of a GI in his platoon who wept after shooting an unarmed man he mistook for a Vietcong fighter. ${ }^{46}$ Puller tells the story of a Marine who was inflicted with permanent "psychic wounds" when he accidentally shot a young girl during a skirmish in a village. ${ }^{47}$ Perhaps the most memorable episode of this kind was recounted by Marine Corps veteran Ron Kovic in his famous memoir, Born on the Fourth of July. Kovic's platoon opened fire on a village it believed housed enemy troops, but when the shooting stopped the Marines discovered that they had "shot up a bunch of kids." After Kovic and his comrades made the harrowing discovery, they cried, fell to the ground, and prayed for God's forgiveness as they desperately tried to help the children they had wounded. ${ }^{48}$

In the northern areas of South Vietnam, American troops often opposed uniformed soldiers of the North Vietnamese Army (NVA) who had crossed over the Demilitarized Zone (DMZ) that separated the South from its northern neighbor. Most GIs, however, fought against the North's allies, the Vietcong guerrillas whose aim was to overthrow the American-allied government of South Vietnam. Vietcong fighters rarely wore uniforms, which made them basically indistinguishable from Vietnamese civilians. The Vietcong looked like ordinary Vietnamese villagers because, in the words of one memoirist, "They were the villagers." 49 The great majority of Vietcong fighters were

\footnotetext{
${ }^{46}$ Brennan, Brennan's War, 61-62.

${ }^{47}$ Puller, Fortunate Son, 130.

${ }^{48}$ Kovic, Born on the Fourth of July, 195-203.

${ }^{49}$ Robert Mason, Chickenhawk (New York: Viking, 1983; Penguin, 2005), 255. Emphasis in the
} original. 
native Southerners, and not, as some proponents of the war claimed, infiltrators from North Vietnam. They were, for the most part, ordinary people, mostly farmers, who had decided to take up arms against their government and its American allies. ${ }^{50}$

In a situation such as this, American troops became justifiably paranoid, learning not to trust any Vietnamese. Several veterans recount instances in which seemingly friendly Vietnamese turn out to be Vietcong, such as the Vietnamese barber who was shot while trying to blow up the barracks that housed his American customers, ${ }^{51}$ or the twelve-year-old boy who was joking with American troops one day, and helping to kill them the next. ${ }^{52}$ Undoubtedly because it conflicted with their pre-Vietnam conception of warfare, memoirists focused a lot of attention on stories of child and women Vietcong. Many of the stories concerning this subject that circulated among the troops, such as accounts of child suicide bombers and enemy agents disguised as prostitutes, were undoubtedly just rumors and exaggerations. Nevertheless, a significant minority of Vietcong fighters were women, ${ }^{53}$ and children were used by the guerrillas to relay messages, act as lookouts, and plant booby traps. ${ }^{54}$ The former infantryman who notes

\footnotetext{
${ }^{50}$ Young, The Vietnam Wars, 79.

${ }^{51}$ Ketwig, And a Hard Rain Fell, 40.

${ }^{52}$ William Broyles, Jr., Brothers in Arms: A Journey from War to Peace (New York: Alfred A. Knopf, 1986), 220.

${ }^{53}$ Sandra C. Taylor, Vietnamese Women at War: Fighting for Ho Chi Minh and the Revolution (Lawrence, KS: University Press of Kansas, 1999), 38, 61, 71, 87-89; Karen Gottschang Turner with Phan Thanh Hao, Even the Women Must Fight: Memories of War from North Vietnam (New York: John Wiley and Sons Inc., 1998), 20-23, 33.

${ }^{54}$ Taylor, Vietnamese Women at War, 95-96.
} 
that there was no way "to distinguish a pretty Vietnamese girl from a deadly enemy" because "often they were one and the same person," was not exaggerating. ${ }^{55}$

War crimes or atrocities occur during every war, and the Vietnam conflict was no different. It is impossible to determine the exact number of atrocities committed in Vietnam, but it is safe to say that they were widespread and committed by all sides in the conflict. Atrocities committed by American troops in Vietnam first became an issue of nationwide concern in the U.S. with the 1969 revelations concerning the My Lai Massacre, an event in which soldiers of the U.S. Army's Americal Division murdered over 200 Vietnamese civilians, most of them women and children. ${ }^{56}$ The horrors of My Lai are important to the history of the war in many ways, but one of its most important, if little known, consequences is that it sparked a massive, secret five-year study conducted by the U.S. Army into American atrocities in Vietnam. Only declassified in 1990 through the Freedom of Information Act, ${ }^{57}$ the study compiled about 800 cases of possible "rapes, torture, murders . . . and other illegal acts" committed by Army personnel, 300 of which were substantiated by further investigation. ${ }^{58}$ There is no way of knowing how many other war crimes never made it into the investigation because perpetrators, witnesses, and victims remained silent.

\footnotetext{
${ }^{55}$ Tim O'Brien, If I Die in A Combat Zone, Box Me Up and Ship Me Home (New York: Delacorte Press, 1973; Delta, 1989), 114.

${ }^{56}$ Herring, America's Longest War, 212; Young, The Vietnam Wars, 243. For a full account of the My Lai Massacre see Seymour M. Hersh, My Lai 4: A Report on the Massacre and its Aftermath (New York: Random House, 1970).

${ }^{57}$ Deborah Nelson, The War Behind Me: Vietnam Veterans Confront the Truth About U.S. War Crimes (New York: Basic Books, 2008), 1-3.

58 Ibid., 3.
} 
The Army based most of its investigation on "sworn statements from soldiers and veterans who committed or witnessed" atrocities. ${ }^{59}$ Not long after the American public learned of the My Lai Massacre, veterans led the way in exposing other war crimes. From January 31 to February 2, 1971, over 100 veterans publicly testified during the Winter Soldier Investigation, an event sponsored by Vietnam Veterans Against the War (VVAW), claiming they had witnessed a wide variety of war crimes while in Vietnam. ${ }^{60}$ A few months later, VVAW member and future U.S. senator, John Kerry, famously summarized the testimonials given by the Winter Soldier participants before the Senate Foreign Relations Committee:

They told stories that at times they had personally raped, cut off ears, cut off heads, taped wires from portable telephones to human genitals and turned up the power, cut off limbs, blown up bodies, randomly shot at civilians, razed villages in fashion reminiscent of Ghengis Khan, shot cattle and dogs for fun, poisoned food stocks, and generally ravaged the countryside of South Vietnam in addition to the normal ravage of war and the normal and very particular ravaging which is done by the applied bombing power of this country. ${ }^{61}$

Several Winter Soldier veterans alleged that the atrocities they had witnessed were not isolated incidents, but integral aspects of U.S. operations in Vietnam. ${ }^{62}$ Such allegations are supported by the experiences of journalists who covered the war.

Journalist Philip Knightly writes in his book, The First Casualty: The War

Correspondent as Hero and Myth-Maker from the Crimea to Iraq, that after news of the May Lai Massacre broke in late 1969, "nearly every war correspondent who had been in

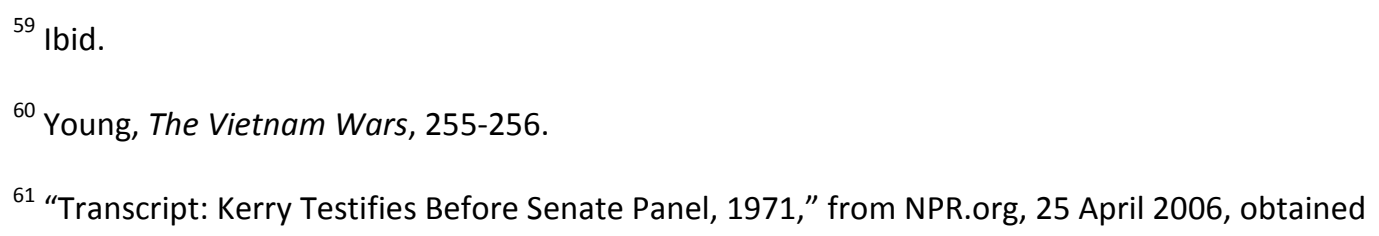
12 Dec. 2008.

${ }^{62}$ Young, The Vietnam Wars, 256. 
Vietnam had an atrocity story to tell."63 The correspondents had not reported these stories earlier "because the killing of civilians [in Vietnam] was not unusual either on a small or on a large scale."64 A journalist, for instance, who saw U.S. Army troops attack a group of woman and children never reported the incident because at the time he did not think it was newsworthy. He had assumed that if he sent "a story about Americans killing Vietnamese civilians" to the news agencies in Saigon they would have rejected it as unexceptional. ${ }^{65}$

There is an apologist attitude towards American atrocities expressed in some prominent veteran memoirs that run counter to how the Winter Soldier speakers dealt with the subject. William Broyles, Jr. suggests in his memoir, Brothers in Arms: A Journey from War to Peace, that the victims of My Lai were partly responsible for their own deaths because they had "watched impassively" when their killers "had been cut to pieces by booby traps all around [their] hamlet." ${ }^{, 66}$ Another memoirist expresses revulsion at the murders at My Lai, but asserts that the issue of atrocities was overblown because civilian deaths are an unavoidable consequence of war. ${ }^{67}$ Caputo admits in $A$ Rumor of War that two of his men had killed a captured Vietcong, and even that he had implicitly ordered the execution. He argues, though, that neither he nor his men were to

${ }^{63}$ Philip Knightly, The First Casualty: The War Correspondent as Hero and Myth-Maker from the Crimea to Iraq (Baltimore, MD: The Johns Hopkins University Press, 2004), 431.

${ }^{64}$ Ibid., 434.

${ }^{65}$ Ibid., 435.

${ }^{66}$ Broyles, Brothers in Arms, 252.

${ }^{67}$ David Donovan, Once a Warrior King: Memories of an Officer in Vietnam (New York: McGrawHill, 1985), 223-224. 
blame for the prisoner's death because the madness of war had driven them to commit the act. $^{68}$

Even though a few memoirists minimized or made excuses for American atrocities, these sentiments are overshadowed by the huge number and wide variety of war crimes that are documented in veterans' narratives. Perhaps the most commonly related atrocities are those committed by American troops against enemy soldiers. Numerous authors give accounts of enemy prisoners being beaten, tortured, or executed by GIs and their Vietnamese allies. Such acts are sometimes depicted as retribution for enemy atrocities, as is the case in the account of an American sergeant who shot a group of bound NVA prisoners because his own comrades had recently been tortured and mutilated after being captured. ${ }^{69}$ In other cases, U.S. soldiers are shown committing atrocities against their enemies out of frustration, such as the two GIs who slashed an enemy corpse with knives because of the rage they felt at all their efforts resulting only in the death of "one lousy dink."70 In still other cases, no obvious reason for such behavior is given at all, as in the story of a veteran who participated in the execution of wounded NVA soldiers because there were "no witnesses in the bush."71

The most disturbing, and probably most frequent, atrocity against enemy combatants that appears in veteran narratives is the taking of enemy body parts as souvenirs, principally ears and skulls. GIs are depicted wearing necklaces strung with

\footnotetext{
${ }^{68}$ Caputo, A Rumor of War, 315-337.

${ }^{69}$ Mason, Chickenhawk, 434-435.

${ }^{70}$ Frederick Downs, The Killing Zone: My Life in the Vietnam War (New York: WW Norton \&

${ }^{71}$ Anderson, Grunts, 121-122.
} Company, 1978), 171-172. 
human ears, ${ }^{72}$ drinking whiskey out of skulls, joking about cooking ears in mess hall soup, ${ }^{73}$ and rigging a skull to open and close its jaw so that it appeared to sing along to music. $^{74}$ Several veterans even claim that they knew of fellow soldiers who took their macabre trophies back home to the United States, or at least hoped to. ${ }^{75}$ Others say that GIs did not just hack up enemy bodies for souvenirs; they also set them in life-like poses to get a laugh out of their comrades. Bodies were propped up, cigarettes put between their fingers ${ }^{76}$ beer cans in their hands,${ }^{77}$ and Playboy magazines placed on their laps. ${ }^{78}$ One memoirist wrote of a fellow Marine who retrieved a "spare leg" from a pile of NVA corpses, "shoved it into the crotch" of another enemy body to create the illusion that the dead man had three legs, and then laughed at his gruesome handiwork "until tears filled his eyes."

All soldiers must dehumanize the enemy to some extent, regardless of race, to become psychologically capable of killing people on the battlefield, but it is clear that race and racism factored in the episodes described above. Seeing that American troops in Vietnam were taught from basic training onwards that the "VC" were inhuman, devilish

\footnotetext{
72 Michael Lee Lanning, Vietnam, 1969-1970: A Company Commander's Journal (Ballantine Books, 1988, College Station, TX: Texas A\&M University Press, 2007), 249; Stanley Goff, Robert Sanders, and Clark Smith, Brothers: Black Soldiers in the Nam (Novato, CA: Presdio Press, 1982), 142.

73 Brennan, Brennan's War, 82, 162.

${ }^{74}$ Mason, Chickenhawk, 387, 395-396.

${ }^{75}$ Bruce Weigl, The Circle of Hahn: A Memoir (New York: Grove Press, 2000), 132-133; Kane, Veteran's Day, 59; Alfred S. Bradford, Some Even Volunteered: The First Wolfhounds Pacify Vietnam (Westport, CT: Praeger Publishing, 1994), 125.

${ }^{76}$ Downs, The Killing Zone, 71-72.

77 Puller, Fortunate Son, 145.

${ }^{78}$ Broyles, Brothers in Arms, 202.

79 Johnnie M. Clark, Guns Up! (New York: Ballantine Books, 1984; 2002), 65.
} 
"gooks" and "dinks," it is unsurprising that enemy corpses were sometimes treated more like slain animals than dead human beings. ${ }^{80}$ One way to prove the racist underpinnings of such practices is to note the behavior of some American troops who fought another Asian enemy, the Japanese, in the Pacific theater of World War II. In War Without Mercy: Race and Power in the Pacific War, historian John W. Dower shows that U.S. soldiers, conditioned to regard the Japanese as akin to insects or apes, also regarded the "gold teeth, ears, bones, scalps, and skulls" of their foes as "battlefield trophies." Dower argues that the "racial dimensions" of this behavior are obvious, noting that "it is virtually inconceivable" that GIs would have collected the body parts of Caucasian war dead as souvenirs. ${ }^{82}$

Memoirists present an accurate depiction of the war by including relatively few examples of Vietcong atrocities committed against civilians in their narratives. The Vietcong certainly threatened, abused, and killed untold numbers of civilians who refused to help them or collaborated with the South Vietnamese government and the Americans. The Vietcong, for instance, killed a large number (the exact figure is disputed) of civilians when they briefly occupied the city of Hue during the 1968 Tet Offensive. ${ }^{83}$ Most of the time, however, Vietcong violence against civilians was small-scale and kept to a minimum, because they, unlike U.S. or ARVN troops, depended on "the people" for

${ }^{80}$ Appy, Working-Class War, 103, 106-107.

81 John W. Dower, War Without Mercy: Race and Power in the Pacific War (New York: Pantheon Books, 1986), 65.

82 Ibid., 66. See pages 64-66 for all of Dower's discussion of American soldiers' usage of Japanese body parts as war trophies.

${ }^{83}$ Young, The Vietnam Wars, 217-218. 
food and shelter. Alienating villagers put the very survival of the Vietcong and the future of their revolution in jeopardy. ${ }^{84}$

American troops were not so obligated to cultivate the goodwill of civilians, and on top of this, civilians looked like the enemy, often aided the enemy, and were generally of a different race than GIs. Veterans document a wide range of war crimes involving civilians in their narratives, including beatings, rape, and murder. Caputo says that on two occasions his platoon went "nuts," turning into "unrestrained savages" who burned down villages in fits of rage. ${ }^{85}$ Another veteran recalled the day when a fellow GI shot an old Vietnamese woman because she stole his pack of chewing gum. ${ }^{86}$ One of the first veteran narratives published was the ghost-written memoir of Lieutenant William Calley, the only American soldier convicted for the murders committed at My Lai. Calley is shockingly frank about his participation in the massacre, but he asserts that killing unarmed women and children was justified because they aided the Vietcong. ${ }^{87}$

Though few narratives can be categorized as definitively "anti-war," many facets of these works put the American venture in Vietnam in a poor light, from the seemingly senseless and ineffective tactics employed by the U.S. military, to the horrendous atrocities attributed to American troops. It seems odd, then, that another reoccurring theme in these accounts is the idea that American soldiers were victimized by the people who suffered the most in the war: Vietnamese civilians. One element of this hatred is

\footnotetext{
${ }^{84}$ Frances Fitzgerald, Fire in the Lake: The Vietnamese and the Americans in Vietnam (Boston: Little, Brown and Company, 1972), 173-175.

${ }^{85}$ Caputo, A Rumor of War, 109-110, 304-305.

${ }^{86}$ Santoli, Everything We Had, 62-63.

${ }^{87}$ Calley, William with John Sack, Lieutenant Calley; His Own Story (New York: Viking Press, 1971), 8-9, 23, 59, 78-80, 84-85, 88-94, 101-103.
} 
easily understood, for it was based on the general unwillingness of civilians to help American troops find their elusive enemies, and even more so, on their active collaboration with the enemy.

The idea of civilians as victimizers, however, goes beyond the role they played in complicating and hindering American combat operations. Part of this theme involves the feeling that even while U.S. soldiers were fighting and dying for South Vietnam's freedom, the majority of its citizens were ungrateful and scornful of these sacrifices. One common manifestation of this attitude in memoirs is the portrayal of South Vietnamese civilians as motivated by a single-minded desire for American dollars. The great majority of Vietnamese civilians who appear in veterans' accounts are people trying to part GIs from their money: beggars, "bargirls," outright prostitutes and their pimps, sellers of shoddy souvenirs, thieves, and hustlers. The people portrayed as the greediest members of South Vietnamese society are the children who constantly swarmed U.S. soldiers wherever they went, pleading for handouts of money, candy, and cigarettes. ${ }^{88}$ One memoirist recalls that on his first day in Vietnam he was initially delighted to see groups of "smiling children ... with grinning teeth and sparkling eyes" waving at him as he passed by in a jeep. ${ }^{89}$ His delight turned to shock when he leaned out of the jeep to wave at a group of boys and they instantly grabbed onto his arm and stole his watch. ${ }^{90}$ Implicated along with civilians as victimizers of U.S. troops are ARVN soldiers, America's primary military allies in South Vietnam. These soldiers, called ARVNs

${ }^{88}$ Historian Christian G. Appy, using fictional and nonfictional veteran narratives, also found that mutual enmity was often evident in the interactions between American soldiers and begging Vietnamese children. Appy, Working-Class War, 133-135.

\footnotetext{
${ }^{89}$ James R. McDonough, Platoon Leader (Novato, CA: Presidio, 1985), 20.

90 Ibid., 20.
} 
(pronounced "arvins") by GIs, are portrayed not as economic exploiters, but as victimizers in the sense that they were too cowardly, lazy, or incompetent to fight, so American troops had to do it for them. The scorn that is heaped upon ARVN troops in veteran narratives cannot be exaggerated. They are called "pathetic" and "chickenshit sons-of-bitches,"91 "fucking cowards" and "babies,"92 and are shown either running away from danger, avoiding the enemy, or acting like happy-go-lucky clowns who would rather lounge around than fight. Puller wrote of an ARVN unit whose members smoked cigarettes, chatted with each other, and listened to transistor radios while on patrol. ${ }^{93}$ Another former lieutenant writes of malevolent "ARVNs" who laughed at American troops marching into the jungle in search of Vietcong while the South Vietnamese soldiers stayed behind and relaxed in hammocks. ${ }^{94}$

Veterans probably express the most anger towards civilians and ARVN troops that initially treated them with "exaggerated kindness," 95 but eventually revealed that their friendliness was a false front screening greed and contempt. Veterans-authors write of begging children who praised Americans when they passed out money and treats, but hurled curses, insults, ${ }^{96}$ and rocks at them when they did not. ${ }^{97}$ One author who worked closely with Vietnamese troops during his tour was touched when his ARVN comrades

\footnotetext{
${ }^{91}$ Downs, The Killing Zone, 77.

92 Kovic, Born on the Fourth of July, 212.

${ }^{93}$ Puller, Fortunate Son, 141.

${ }^{94}$ Downs, The Killing Zone, 202.

${ }^{95}$ Broyles, Brothers in Arms, 136.

${ }^{96}$ Caputo, A Rumor of War, 107.

${ }^{97}$ Broyles, Brothers in Arms, 220-221.
} 
surprised him with a farewell dinner a few days before his flight home to the U.S. When his Vietnamese hosts broke out into hysterical laughter during the meal he realized that the dinner was not meant to honor him, but to set him up for a cruel practical joke; they had fed him his dog. ${ }^{98}$

Besides being portrayed as pitiless exploiters, most of the Vietnamese who appear in veteran narratives basically serve as scenery or props. These faceless, voiceless, and nameless figures are the "villagers," "people," or "gooks" with whom GIs briefly interact as they pass through villages and cities. The occasional Vietnamese who rise above this background status in veteran narratives are invariably only one-dimensional caricatures who speak in snippets of broken English and GI slang. Caputo, for instance, records begging children saying "gimme cig'rette gimme candy you buy one Coka. One Coka twenty P you buy," and a teenager who says, "hokay, hokay. Kill buku VC."99 Save for a few exceptions, the readers of these narratives are never presented with a Vietnamese who seems like a real human being with thoughts, feelings, and complex motivations for his or her actions.

The Vietnamese, of course, were real people, and many had good reasons for acting in ways that American soldiers found annoying or despicable. So many Vietnamese seemed to be greedy exploiters because the war devastated South Vietnam's economy. For many Southerners, prying dollars away from comparatively wealthy American servicemen was their best option for survival. ${ }^{100}$ Before the war, the great

\footnotetext{
${ }^{98}$ Tobias Wolff, In Pharoah's Army: Memories of the Lost War (New York: Alfred A. Knopf, 1994),
} 188-189.

${ }^{99}$ Caputo, A Rumor of War, 107.

${ }^{100}$ Fitzgerald, Fire in the Lake, 348-353; Appy, Working-Class War, 289-291. 
majority of South Vietnamese lived in rural areas and relied on agriculture, principally rice production, for their livelihoods. The countryside became increasingly dangerous as the war escalated, and U.S. forces, as part of their "pacification" efforts, destroyed villages and laid waste to farmland with bombs and the infamous chemical defoliant, "Agent Orange." These developments led to an exodus of rural people to the cities, ${ }^{101}$ causing "the urban population of South Vietnam [to increase] from 15 to 40 percent of the total population" by $1968 .^{102}$ With much of its rice crop destroyed, and the farmers who tended those crops fleeing their fields, South Vietnam, "normally a rice-exporting area," was forced to import rice by $1967 .{ }^{103}$

Deprived of their livelihoods, rural refugees who settled in city slums or shantytowns surrounding U.S. bases were forced by necessity to get what they could from the Americans. For many this meant working as laborers or maids on American bases, but for others it meant pursuing more illicit occupations. ${ }^{104}$ An example of how this process played out for one South Vietnamese citizen is found in the memoir of Le Ly Hayslip, When Heaven and Earth Changed Places. Hayslip spent the earliest years of her life in a rural village, but was forced to flee to Saigon after the local Vietcong cadre sentenced her to death because they mistakenly believed she was a government informant. Still just a young girl, Hayslip became pregnant, and to provide for her child she first made money by peddling black-market American goods to U.S. soldiers. Eventually, she lived with a series of American boyfriends who paid her expenses, a

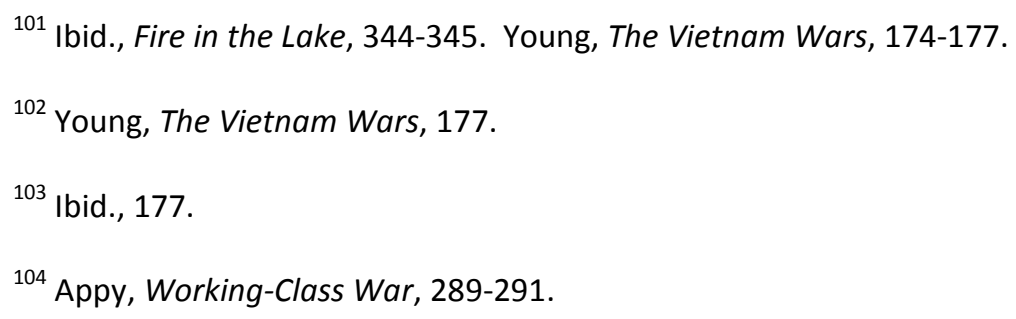


route taken by her sister and many other South Vietnamese women at the time. Hayslip also admits that on one occasion, after being offered what to her was a fabulous amount of cash, she reluctantly had sex with an American soldier for money. ${ }^{105}$

In addition to disruptions caused by the random destructiveness of war, the lives of millions of South Vietnamese were upset by their government's "strategic hamlet" program. Initiated in 1962 by South Vietnam's first president, Ngo Dinh Diem, this strategy was designed to separate the Vietcong from the civilian population by forcibly removing peasants from their villages and relocating them to fortified government-run camps. ${ }^{106}$ After watching their old homes burned to the ground, villagers conscripted into the program were then forced to build their new homes themselves. The peasants were charged for "building materials provided free by the United States" to the Saigon government, including the barbed wire that was strung around their inferior housing. ${ }^{107}$ After suffering such indignities, relocated peasants were "motivated as never before to support the Viet Cong."

The great economic and social upheavals caused by the war also gave many South Vietnamese good reasons to treat American troops with hostility and contempt. Prior to the "American War," many of South Vietnam's peasants followed a way of life that had changed little for thousands of years. Life for such people revolved around rice agriculture and family, and for most, leaving one's village and the graves of the ancestors

\footnotetext{
${ }^{105}$ Le Ly Hayslip and Jay Wurts, When Heaven and Earth Changed Places (New York: Doubleday, 1989), 86-97, 168-174, 184-185, 256-326.

${ }^{106}$ Neil Sheehan, A Bright Shining Lie: John Paul Vann and America in Vietnam (New York: Random House, 1988), 124, 309-311

107 Ibid., 310.

108 Ibid., 311.
} 
was anathema. ${ }^{109}$ It is not surprising that people whose villages and crops may have been wiped out by American bombs and chemicals were unfriendly towards Americans. The South Vietnamese would be even more likely to dislike Americans if they had family members or friends who had been killed or maimed in the fighting, as was the case for millions of people. During the early 1990's, journalist Martha Hess travelled throughout Vietnam and interviewed people about their memories of American bombings and atrocities, eventually converting their accounts into a book, Then the Americans Came: Voices from Vietnam. One man posed a question to Hess that was echoed by several other interviewees: "With all the American soldiers did to the Vietnamese people, how can we not hate them?"110

Along with their own alienating behavior, American troops were tainted in the eyes of many South Vietnamese because their stated mission was to protect a South Vietnamese government that was corrupt, inept, oppressive, and thoroughly undemocratic. The corrupt government officials propped up by American power really represented only a relatively small class of urban elites. Many high-level Saigon officials, including President Diem, were Roman Catholics, while the majority of Vietnamese were Buddhists. Vietnamese were also suspicious of and hostile to American troops because they were a foreign army, and Vietnam had a long history of resistance to foreign invaders. Rightly or wrongly, such a history led many Vietnamese to regard the Americans as the successors to the French colonialists who had been driven out of Southeast Asia years earlier.

${ }^{109}$ Fitzgerald, Fire in the Lake, 7-16.

${ }^{110}$ Martha Hess, Then the Americans Came: Voices from Vietnam (New York: Four Walls Eight Windows, 1993), 193. 
All of these reasons for hating Americans also served as compelling motivations to join the Vietcong insurgency. Whereas the South Vietnamese government frequently acted imperiously and without regard to the sensitivities of its people, the Vietcong generally adhered to policies designed to win villagers to its side. The Vietcong also produced propaganda that successfully appealed to ordinary Vietnamese, whereas the Saigon government was never really willing or able to convince many people of its worthiness to rule. ${ }^{111}$ One Vietcong prisoner told his American interrogators that he had joined the insurgency because he was a poor farmer, and the message of the Vietcong "propaganda cadres," that he had been exploited by the government and the rich landlords it represented, appealed to him. ${ }^{112}$ It is likely that relatively few South Vietnamese fully believed in the ideology of the Communists who dominated the Vietcong's leadership. ${ }^{113}$ Large numbers of Vietnamese nevertheless joined the insurgency because they, like the prisoner, saw it as the only alternative to a distasteful government seemingly controlled by the "puppets" of foreign imperialists. ${ }^{114}$

Another significant reason why many rural South Vietnamese hated their national government was because it drafted thousands of their sons into the ARVN, causing catastrophic labor shortages in rice growing areas. Rice agriculture in South Vietnam was labor intensive, and when the young men who performed much of that labor marched off to war, peasants suffered greatly. Maintaining a labor supply was so important that

${ }^{111}$ Fitzgerald, Fire in the Lake, 103-107, 143-145, 158-163, 299; Young, The Vietnam Wars, 60-69, 103.

112 David Chanoff and Doan Van Toai, Portrait of the Enemy (New York: Random House, 1986), 42-43.

${ }^{113}$ Young, The Vietnam Wars, 70-71. Although Communists dominated the Vietcong, noncommunists fought under its banner as well.

${ }^{114}$ Sheehan, A Bright Shining Lie, 192-193. 
village leaders frequently helped local men avoid military service. In 1964, farmers in the Mekong Delta blocked roads in protest against conscription policies that emptied their fields of workers. Ever eager to exploit anti-government sentiment, the Vietcong provided peasants with workers who aided in planting and harvesting. ${ }^{115}$

The major unrest caused by the draft also indicates that there was more to ARVN troops than the scathing portrayals included in American veterans' memoirs. Veterans were correct in their assessment of the ARVN as a generally terrible fighting force. Despite having been provided with millions of dollars in U.S. military aid since 1955, the ARVN was still no match for the Vietcong on the eve of direct American intervention in the war. In January 1963, a chagrined Kennedy White House learned that ARVN troops near the village of Ap Bac had been routed by a much smaller force of Vietcong guerrillas. Nearly a decade later, a February 1971 ARVN incursion into Laos ended prematurely and disastrously when its troops suffered a 50 percent casualty rate after clashing with enemy Vietnamese forces using that country as a sanctuary. The South Vietnamese military suffered a final humiliation when it was swept aside by the NVA and the Vietcong during their surprisingly swift 1975 takeover of South Vietnam. ${ }^{116}$

The true reasons for the poor performance of ARVN troops, however, are not mentioned in the narratives of American veterans. It is significant that in "the ARVN's twenty-year life (1955-1975), drafted soldiers represented about 65 percent of the army's

\footnotetext{
${ }^{115}$ Robert K. Brigham, ARVN: Life and Death in the South Vietnamese Army (Lawrence, KS: University Press of Kansas, 2006), 13-18.

${ }^{116}$ Herring, America's Longest War, 88, 235, 259-261. For more information on the Battle of Ap Bac see Sheehan, A Bright Shining Lie, 201-267. Sheehan's book is a good source in general for learning about the failings of the ARVN and the South Vietnamese government during the war.
} 
total troop levels, making it one of the most heavily conscripted armies in history." The ARVN was made up largely of draftees who only submitted to conscription because not doing so meant being arrested, a fate that often resulted in imprisonment, torture, or death. South Vietnamese men did not want to fight for the ARVN because it served an oppressive and corrupt government that frequently displayed blatant contempt for its own people. The prospect of serving in the South Vietnamese military was made further distasteful by the post-1968 requirement that ARVN troops, unlike American GIs with their one-year tours of duty, could not return to civilian life until the war ended. During that indefinite period of service, the average soldier was allowed only 15 days a year of "leave" time to visit with family and friends.

South Vietnamese recruits learned very soon after enlistment that any reticence they had about serving in the military was well founded, with even patriotic volunteers (and there were some) concluding that they had made a big mistake. In the first days, even weeks after enlistment, ARVN troops often spent their days idly waiting in crowded rooms for paperwork to be processed, the necessary officials to appear, or their equipment to arrive. During these days of boredom and incessant waiting a recruit might have to sleep on the floor due to lack of beds. When recruits finally made it past this stage they were given completely inadequate training; their instructors were largely incompetent and without combat experience. ${ }^{118}$ ARVN soldiers left basic training keenly aware of how unprepared they were for combat, and it gave them "the sinking feeling that they were no match for the Communists." ${ }^{119}$ ARVN troops were understandably

\footnotetext{
${ }^{117}$ Brigham, ARVN, 7.

118 Ibid., 7-8, 11, 27-44, 50.
} 
concerned that their poor training would prove fatal, and many feared that if sent into battle they would be killed before firing a shot. ${ }^{120}$

This background information about the ARVN is key to understanding why its troops acted in ways that smacked of cowardice, but it is not included in the memoirs of any American veterans. Besides occasionally mentioning the extent of poverty in wartime South Vietnam, most veterans do not speak of the real reasons for the behavior of civilians that they witnessed either. Without this contextual information, readers of these books learn little about the Vietnamese people and how they experienced the war, and the little they do learn is often inaccurate.

It is not the fault of veterans that the information they had about the Vietnamese was extremely limited, and often false. Most GIs left for war with almost no knowledge of Vietnam and its people. American soldiers were not encouraged to learn about Vietnam and its people, and because the U.S. government had the resources to bring American culture to Southeast Asia, they did not have to. If they so desired, most GIs could spend all of their tours in Vietnam eating American food, listening to American music, watching American television programs and movies, and socializing only with other Americans. Considering that U.S. soldiers were thousands of miles away from home, facing the possibility of death or injury, and often did not want to be there in the first place, this was a perfectly understandable attitude. Even those who wanted to learn more about Vietnam and interact with its people were inevitably hampered by their inability to speak their language. It is no surprise, then, that many American soldiers probably left Vietnam knowing almost as little about the country as when they arrived.

\footnotetext{
119 Ibid., 27.

120 Ibid., 36.
} 
The soldiers' ignorance of Vietnam was a trait they shared with most other Americans of the era, from ordinary citizens to those in the highest levels of academia and government. ${ }^{121}$ Robert S. McNamara, the U.S. Secretary of Defense from 1961 to 1968, admits in his controversial book, In Retrospect: The Tragedy and Lessons of Vietnam, that with the Vietnamese, he and other policymakers were dealing with "a people whose language and culture we did not understand and whose history, values, and political traditions differed profoundly from our own." ${ }^{122}$ For most of the war, the U.S. government expended little effort in preparing military personnel or civilians to understand or even speak with the people living in the country it was committed to save from Communism. ${ }^{123}$ By 1968, “American statecraft possessed in all probably 40 men with a crude understanding of Vietnamese language and culture, with less than 20 of those in the field, responsible for guiding half a million American troops."

Although John Ketwig, the author of A Hard Rain Fell, hated military life from day one, and regarded his assignment to Vietnam as akin to a death sentence, he also initially saw his tour in Southeast Asia as a potentially illuminating "adventure" in an “exotic, ancient land."125 At first, Ketwig thought his strange surroundings in Vietnam resembled the "curious cultures" he had read about in National Geographic magazine,

${ }^{121}$ Theodore H. White, The Making of the President, 1968 (New York: Atheneum, 1969), 16-17.

${ }^{122}$ Robert S. McNamara with Brian VandeMark, In Retrospect: The Tragedy and Lessons of Vietnam (New York: Times Books, 1995), 43. For all of McNamara's comments on the American leadership's ignorance of the Vietnamese see pages 32-33, 321-323.

${ }^{123}$ White, The Making of the President, 16-17.

124 Ibid., 17.

${ }^{125}$ Ketwig, And a Hard Rain Fell, 39. 
but as time passed, he became disappointed and disgusted by South Vietnam and its people. Ketwig had sought an "exotic, inscrutable Asian culture,"126 but found instead piles of garbage, brothels, gift shops selling "cheap gaudy souvenirs," and Vietnamese only interested in either killing GIs or cheating them out of their money. ${ }^{127}$

Due to these experiences, Ketwig offered readers a mostly unfavorable depiction of the Vietnamese people. His depiction was not unique, however, for veterans' narratives in general portray the Vietnamese negatively, branding them as greedy, treacherous, and cowardly. What Ketwig and most other veterans did not include in their narratives were explanations for the Vietnamese behaviors and attitudes they witnessed. If they had, readers would have learned that the South Vietnamese seemed like greedy victimizers because the war had upended their nation's economy. They would have also learned that many South Vietnamese joined the Vietcong because they wanted to get rid of an oppressive government; and that ARVN soldiers often avoided battle or fought poorly not because they were cowards and imbeciles, but because they suffered from terrible training and morale.

Veterans are not to blame for the lack of appropriate context in their memoirs, for most of them, like most Americans, were not privy to the reasons behind South Vietnamese actions. This highlights the danger of only using U.S. veteran narratives to learn about the war, for these accounts are inherently limited in scope. On the other hand, such accounts are extremely valuable sources for learning about what combat was like for the soldiers who did the fighting. The architects and managers of the Vietnam
${ }^{126}$ Ibid., 63.
127 Ibid., 63-66. 
War, the generals and statesmen, can give us insight into the grand strategies they employed during the conflict, but former soldiers can tell us how those strategies played out on the battlefield. From the accounts of former infantrymen, readers learn what happened when demands for higher "body counts" trickled down to platoon-level, or what the "pacification" of enemy-controlled areas looked like from the perspective of the GIs who did the pacifying. Because veteran narratives generally depict combat in a realistic fashion, readers are confronted with a view of warfare that is as authentic as it is terrifying. 


\section{CHAPTER FOUR}

\section{RACE AND RACISM}

Frederick Downs, author of the memoir, The Killing Zone: My Life in the Vietnam War, served in Southeast Asia as a lieutenant leading an Army infantry platoon. Downs, who is white, notes in the book that his platoon included soldiers of various races and ethnicities: "whites, blacks, Puerto Ricans, Mexican-Americans, an Indian, and a Japanese-American." ${ }^{11}$ He asserts that the diversity of the platoon caused no problems because the soldiers evaluated each other on the "ability to help the platoon survive," and not on racial or ethnic heritage. ${ }^{2}$ These statements say a lot about Downs' view of race relations in Vietnam, but these few sentences are all that he writes about the subject. Ironically, however, he devotes more attention to racial issues than other white veterans, most of whom mention nothing about race at all.

If one reads only the narratives of white veterans for information about the war, it seems as if race was not an issue at all in Vietnam, or, at the most, a marginal one. In reality, the opposite was true: the story of America's long, ill-fated conflict in Southeast Asia cannot be fully told without exploring racial issues. The war not only coincided with the most significant African-American civil rights movement since Reconstruction, but it was also the first American war fought by fully-integrated troops since the nation

\footnotetext{
${ }^{1}$ Frederick Downs, The Killing Zone: My Life in the Vietnam War (New York: Norton, 1978), 37. ${ }^{2}$ Ibid.
} 
was founded. In the U.S., the war was the focus of debate among civil-rights leaders and in the black community at large. America's enemies in Vietnam used its racial problems for propaganda purposes, and in the final stages of the war, racial violence in the U.S. military reached catastrophic levels. In addition to all this, large numbers of other nonwhite minorities, Puerto Ricans, Native Americans, and many others, also fought in Vietnam, a situation that led to debate and turmoil within their respective communities as well.

The lack of attention to racial issues among white veterans would not be a problem if a sufficient number of minority veterans' memoirs were available to provide counterbalancing perspectives. Unfortunately, this is far from the case. The number of published minority narratives is tiny compared to those written by whites, and the number that achieved any critical or popular success is even smaller. Still, despite their relative rarity and lack of recognition, these accounts represent the best means of learning about the experiences of nonwhite soldiers. Few films ${ }^{3}$ and novels focus on minority soldiers, and though several white veterans have written successful novels about the war, they have virtually no minority counterparts. ${ }^{4}$ Historians have written relatively little about

\footnotetext{
${ }^{3}$ Two major films have been made about the experiences of African-American soldiers in Vietnam: The Walking Dead, Directed by Preston A. Whitmore II (1995) and Dead Presidents, Directed by Albert Hughes and Allen Hughes (1995). No films have focused on the experiences of other nonwhite groups. Many other Vietnam War movies feature black characters, but some have criticized the portrayal of these soldiers and alleged that nonwhites are never present in large enough numbers. "Blacks Blast Movie and TV Industries' Perpetuation of Old Stereotyped Images," Jet, 28 November 1988, 64.

${ }^{4}$ Scholar Herman Beavers stated in 1989 that "one is hard pressed to find in Afro-American literature more than three novels that center on the Vietnam experience." Herman Beavers, "Contemporary Afro-American Studies and the Study of the Vietnam War," Vietnam Generation 1, no. 2 (1989): 8. As of 1997, only 6 of the 600 published Vietnam novels were authored by African Americans, only three of them veterans. All of these books were published before 1986, and none achieved any kind of commercial success. Jeff Loeb, "MIA: African American Autography of the Vietnam War," African American Review 31, no. 1 (Spring 1997): 105. Five novels about Mexican-American soldiers in Vietnam have been published since 1988, four of them authored by Chicano veterans. None of these books
} 
African-American soldiers who served in Vietnam, ${ }^{5}$ and almost nothing about their counterparts who belonged to other nonwhite groups. ${ }^{6}$ Published narratives of black veterans have been used as primary sources by the handful of historians who have written on the topic, but none have considered these documents worthy of analysis in their own right. In fact, the only existing piece of scholarship that focuses wholly on black veteran narratives is a single journal article written by a literary scholar. ${ }^{7}$ The published narratives of other nonwhites have not been used in any capacity by any scholar.

To overcome this glaring deficiency in the literature dealing with Vietnam veterans' memoirs, this chapter provides an extensive analysis of narratives by nonwhite veterans, including memoirs, oral histories, and article-length narratives published in African-American centered periodicals. African Americans, Native Americans, and Mexican Americans are the primary groups represented in these works, along with smaller numbers of other nonwhite peoples. These works as a whole constitute what journalism historian Carolyn Kitch calls a "counter-memory" of the war. Counter-

evidently achieved much recognition either. John Alba Culter, “Disappeared Men: Chicana/o Authenticity and the American War in Viet Nam," American Literature 81, no. 3 (September 2009), 585.

${ }^{5}$ For over twenty years, the only scholarly treatment of African Americans in Vietnam was the final chapter of Jack D. Foner, Blacks and the Military in American History: A New Perspective (New York: Praeger, 1974), 200-220. The first, and still the best, book-length historical study of black troops is James Westheider, Fighting on Two Fronts: African Americans and the Vietnam War (New York: New York University Press, 1997). Three other books about the subject were subsequently published: Herman Graham, The Brothers' Vietnam War: Black Power, Manhood, and the Military Experience (Gainesville, FL: University Press of Florida: 2003), Natalie Kimbrough, Equality or Discrimination?: African Americans in the U.S. Military During the Vietnam War (Lanham, MD: University Press of America, 2007), and James Westheider, The African American Experience in Vietnam: Brothers in Arms (Lanham, MD: Rowman and Littlefield Publishers, 2008). Westheider's second book is essentially a simplified, scaled down version of his first book, apparently intended for undergraduate students.

${ }^{6}$ There is only one book-length scholarly study of non-African-American, nonwhite soldiers who served in Vietnam: Tom Holm, Strong Hearts, Wounded Souls: Native American Veterans of the Vietnam War (Austin, TX: University of Texas Press, 1996). The only other piece of historical scholarship about non-black, nonwhite soldiers is: Lea Ybarra, "Perceptions of Race and Class among Chicano Vietnam Veterans," Viet Nam Generation 1, no. 2 (1989): 69-93.

7 Jeff Loeb, "MIA: African American Autography," 105-123. 
memories document past events in ways that challenge how those events are remembered in dominant, mainstream culture. African-American counter-memory typically challenges the mainstream by "recounting known history in a way that points out racism" and highlights black accomplishments. ${ }^{8}$ Minority veterans' narratives precisely fit the definition of a counter-memory because their collective portrayal of the war is racecentric, whereas most white writers mention little or nothing about racial issues. Most nonwhite memoirists viewed nearly every aspect of their Vietnam experience through the lens of race.

This is not to say, however, that the counter-memory represented in nonwhite memoirs is exclusively concerned with racial issues, for these documents offer a complex depiction of the war beyond the question of race per se. The overall portrayal of the war by minority veterans is best described as two competing, antagonistic versions, one positive, the other negative. The first version is not positive in being "pro-war" or "hawkish" in its assessment of the Vietnam conflict, as very few minority narratives evince support for the war aims of United States. Instead, this version offers a portrayal of the war that is reminiscent of the confirmatory attitude that African Americans and other nonwhites have traditionally held towards wartime military service. This attitude is composed of two parts: emphasis on racial cooperation and friendship, and expression of pride in the performance of one's own racial or ethnic group in the war.

The second version of the war is, in many ways, the opposite of the first, since it focuses on incidents of white racism and self-segregation. Whereas many aspects of the first version echo traditional minority attitudes towards military service, the second

\footnotetext{
${ }^{8}$ Carolyn Kitsch, Pages from the Past: History and Memory in American Magazines (Chapel Hill, NC: The University of North Carolina Press, 2005), 93.
} 
version is seemingly influenced by the Black Power movement. The Black Power movement arose in the U.S. in the late 1960's when young black activists, rejecting the pacifist, integrationist foundations of the Civil Rights Movement, broke away from their elders to pursue more militant approaches to achieving freedom for African Americans. ${ }^{9}$ From the late 1960's until American troops withdrew from South Vietnam in 1973, the Black Power movement had a great presence among African-American troops in Vietnam. ${ }^{10}$ The influence of the movement on minority soldiers is evident in the memoirs of nonwhite veterans, who often articulated approval of aspects of Black Power ideology, including racial separatism, cultural nationalism, solidarity among nonwhite peoples, and specific arguments against the war.

This competition between two perspectives on the war occurs between different narratives, as some veterans emphasize one version over the other; but it also occurs within narratives, since veterans sometimes voice sentiments which support one view, then a few pages later make statements that support the other, often contradicting the first version in the process. The complicated nature of nonwhite veteran portrayals of the war reflected nonwhite attitudes towards the war were equally complex. All nonwhites, civilians and soldiers alike, were confronted with conflicting viewpoints on Vietnam, some reflecting older traditional notions of military service, others adhering to newer, more radical ways of thinking. It would have been difficult for anyone in such a situation to make sense of the war, but even more so for the soldiers who had to fight it.

\footnotetext{
${ }^{9}$ For general information about the Black Power movement see William L. Van Deburg, New Day in Babylon: The Black Power Movement and American Culture, 1965-1975 (Chicago: University of Chicago Press, 1992), and Peniel E. Joseph, Waiting 'Till the Midnight Hour: A Narrative of Black Power in America (New York: Henry Holt and Company, 2006).

${ }^{10}$ Van Deburg, New Day in Babylon, 102-106.
} 
Military commanders, convinced that black men were unfit to fight, relegated African-American troops to noncombat duty during the early stages of most American wars before Vietnam. (President Harry Truman ordered the desegregation of the military in 1948, and some integrated units saw action in the Korean War; but since the military was not officially desegregated until 1954, the Vietnam conflict was the first real test for the colorblind military.) In response, black leaders, convinced that wartime military service would be indisputable proof to white America that they deserved the full benefits of citizenship, waged "right to fight" campaigns. Although such campaigns were successful, and black men invariably proved their valor when they were given the chance to fight, these advances were usually forgotten or ignored by whites not long after a conflict concluded. ${ }^{11}$ Some African Americans initially viewed the Vietnam War in the same way, but attached even more importance to this conflict since it was the first conflict since the Revolution fought by a truly integrated Army. Hence, they offered support for the conflict early on, applauding the fact that blacks and whites were serving jointly in Southeast Asia. African-American magazines and newspapers of the period championed these concepts as well, ${ }^{12}$ and were often full of photographs of white and black GIs working together Vietnam. ${ }^{13}$

${ }^{11}$ Graham, The Brothers' Vietnam War, 1-14.

${ }^{12}$ Westheider, Fighting on Two Fronts, 8-12; Nikolas Kozloff, "Vietnam, the African American Community, and the Pittsburgh New Courier," Historian 63 (Spring 2001): 521-522, 525, 528, 532-533.

${ }^{13}$ A November 1965 Ebony article, for instance, featured a large photograph of two young Army troopers in the $173^{\text {rd }}$ Division, one white, one black, sharing a foxhole near Bien Hoa, South Vietnam. Even at this early date, however, the caption noted that while camaraderie was the rule in the field, "social segregation often exists." Simeon Booker, "Negroes in Vietnam: 'We Are Americans Too,'" Ebony, November 1965, 98. 
Before about 1968, the mainstream media also highlighted and praised the integrated nature of American forces in Vietnam. In January 1966, The New York Times published an article about Vietnam entitled "Negro and White Fight Side by Side." ${ }^{4}$ As late as May 1967, a Time article entitled "Armed Forces: Democracy in the Foxhole," asserted that "Black-white relations in ... [Vietnam] are years ahead of Denver and Darien [Connecticut], decades ahead of Birmingham and Biloxi."15 The article's author apparently believed that race relations in Vietnam were better than in Southern U.S. cities that had been wracked by years of racial unrest, but also in Northern locales that had experienced relatively few racial problems. A documentary, Same Mud, Same Blood, which focused on the interracial amity that supposedly reigned in Vietnam, would appear on national television later that year. ${ }^{16}$

By 1968, the mainstream media no longer praised the integrated nature of the fighting force in Vietnam, and most African Americans---leaders, media figures, and ordinary people alike---had probably turned against the war even earlier. Testimony to the beneficial effects of the integration of the troops in Vietnam, however, did live on as part of the positive version of the war depicted in nonwhite narratives. One black memoirist, for instance, periodically brings up this theme in his book, ${ }^{17}$ concluding "that in war a man is a man ... someone you can rely on, and you don't worry about the color of [his] face." ${ }^{\prime 18}$ Many memoirists clearly regard the formation of friendships with whites

\footnotetext{
${ }^{14}$ R.W. Apple, Jr., "Negro and White Fight Side by Side," The New York Times, 3 January $1966,7$.

15 “Armed Forces: Democracy in the Foxhole," Time, 26 May 1967.

16 “Huckleberry Finn in Vietnam,” New Republic, 6 January 1968.

${ }^{17}$ Samuel Vance, The Courageous and the Proud (New York: W.W. Norton and Company, 1970),
} 63-64. 
in Vietnam as profound moments in their lives. Another black veteran wistfully recalls that he was so close to a white soldier in his platoon that "he should've been [his] brother." ${ }^{19}$ And another says that the personal relationships he formed with whites were the only positive aspects of his combat tour. ${ }^{20}$ Such veterans sometimes lament that the interracial unity of the war was absent from their post-war lives, and wish that such experiences could be replicated on a grand scale in the United States. ${ }^{21}$

In contrast to this appreciation of racial integration and cooperation is the negative version's emphasis on segregation as a way of life in Vietnam. The separation of the races was especially prevalent when GIs were free to pursue leisure activities, many of which revolved around alcohol and prostitution. In Saigon, South Vietnam's capital city, white servicemen in search of a good time headed to Tu Do Street, while African Americans went to Khanh Hoi Street, better known as "Soul Alley." The savvy entrepreneurs of Soul Alley offered black troops all the comforts of home: "soul food" restaurants, bars with "soul music" on the juke box, and brothels that employed darkskinned Cambodian women. ${ }^{22}$ Khanh Hoi Street, Time reported in 1970, even had a semi-permanent population of "between 300 and 500 black AWOLS and deserters" who lived there as fugitives from military justice. ${ }^{23}$ Soul Alleys grew up in other areas of

${ }^{18}$ Ibid., 158.

${ }^{19}$ Al Santoli, Everything We Had: An Oral History of the Vietnam War by Thirty-Three American Soldiers Who Fought It (New York: Random House, 1981; Ballantine, 1983), 157.

${ }^{20}$ Stanley Goff, Robert Sanders, and Clark Smith, Brothers: Black Soldiers in the Nam (Novato, CA: Presdio Press, 1982), 131.

${ }^{21}$ Ibid., 122-123, 131.

22 "South Viet Nam: Soul Alley," Time, 14 December 1970.

${ }^{23}$ Ibid. 
South Vietnam besides Saigon, and establishments in other cities around the globe catered exclusively to either black or white servicemen. ${ }^{24}$

Throughout much of the twentieth century, including during the Vietnam era, African-American GIs stationed overseas were often banned from bars and brothels frequented by white troops, their activities limited to subpar "negro" establishments. ${ }^{25}$ By the 1960's, segregation of such locales was most often instituted by business owners who acceded to the racist attitudes of their white customers. ${ }^{26}$ White racism, however, was not always the only reason behind the segregation of leisure activities in the Vietnam era. The "white" bars and brothels of Tu Do Street and other locales were certainly unofficially off-limits to nonwhites, but at the same time, African-American servicemen themselves embraced the type of segregation represented by Soul Alley businesses. A 1969 survey of African-American enlisted men serving in Vietnam, conducted by Time correspondent Wallace Terry, found that a majority of black troops preferred to eat, live, and socialize only with other African Americans. ${ }^{27}$ "Soul" bars and restaurants are portrayed in the memoirs of black veterans as wonderful oases where African Americans could socialize in familiar and comforting surroundings. One former Marine describes a

${ }^{24}$ Charles C. Moskos, Jr., The American Enlisted Man: The Rank and File in Today's Military (New York: Russel Sage Foundation, 1970), 125.

${ }^{25}$ From the beginning of the American occupation of Japan, for instance, prostitutes were apportioned "into separate districts ... reserved for use by U.S. officers, white enlisted men and black enlisted men." John Dower, Embracing Defeat: Japan in the Wake of World War II (New York: W.W. Norton \& Company, 1999), 130. In a Vietnam-era example of such forced segregation, African-American troops stationed near Anjong-ni, South Korea rioted in July 1971 because they were denied access to bars and prostitutes. Stuart H. Loory, Defeated: Inside America's Military Machine (New York: Random House, 1973), 219-220.

${ }^{26}$ Moskos, The American Enlisted Man, 125.

${ }^{27}$ Wallace Terry II, "Bringing the War Home," Black Scholar, November 1970, 14. A short summary of the findings and observations Terry included in this article later appeared in "Black Power in Viet Nam," Time, 19 September 1969. 
soul bar in Japan, a place which featured "funky music," "huge plates full of chitlins," and lots of friendly "brothers," as "heaven" for black GIs far from home. ${ }^{28}$

The self-segregation practiced by many black soldiers in the late 1960's was strongly influenced by the Black Power Movement, which was very much a cultural force in Vietnam during this period. One of the main reasons the Black Power generation of activists rejected their elders in the Civil Rights Movement was the latter group's focus on integration. Given the violent reactions of whites towards demands for desegregation, the younger activists saw the integrationists' dream of a future American society in which “dissimilar peoples would . . accept and love one another," as a fantasy. ${ }^{29}$ Black Power proponents, echoing ideological predecessors such as Malcom $\mathrm{X},{ }^{30}$ believed that separation from whites was the only way to achieve the two goals that would lead to true freedom for African Americans: self-reliance and self-determination. Complimentary to racial separation in the minds of many Black Power advocates was the celebration of African-American history and culture, and a general pride in being black. ${ }^{31}$ One can easily see the confluence of these two elements of Black Power theory, separatism and cultural nationalism, in the stories of black soldiers reveling in the sights, sounds, and smells of soul bars and restaurants.

Self-segregation was the rule not just in bars, brothels, and the like, but throughout "the rear," the term used by GIs to denote any area of South Vietnam that was

\footnotetext{
${ }^{28}$ Terry Whitmore and Richard P. Weber, Memphis, Nam, Sweden: The Story of a Black Deserter (New York: Doubleday, 1971; reprint, Jackson, MI: University Press of Mississippi, 1997), 98-99.

${ }^{29}$ Van Deburg, New Day in Babylon, 43.

${ }^{30}$ For information on the ideological precursors and origins of the Black Power movement see the first five chapters of Joseph's Waiting Till the Midnight Hour, pages 1-117.

${ }^{31}$ Van Deburg, New Day in Babylon, 43-45, 51-53, 113-116, 129-145. See also Joseph, Waiting Till the Midnight Hour.
} 
relatively safe from enemy attack. Some memoirists suggest that this inclination towards racial separatism was so strong that it manifested itself not just in the rear, but whenever and wherever interracial cooperation was not absolutely necessary, including during combat operations. It was in everyone's best interest to work together during a firefight, but during "quiet times," GIs invariably "gravitated towards their own kind," "whites . . . with whites, blacks with blacks, Chicanos with Chicanos," noted one of the few Hispanic veterans who published a memoir about his experiences in Vietnam. ${ }^{32}$ As this last quote suggests, self-segregation was not just a black-white phenomenon, but was practiced by soldiers of all races and ethnicities. Apparently, any time two or more soldiers of the same race or ethnicity were present in a unit, they formed an exclusive social group. There was apparently little intermingling between the various nonwhite peoples represented in the U.S. military. Even the two biggest Hispanic groups in Vietnam, Mexican Americans and Puerto Ricans, sometimes stayed apart from each other. ${ }^{33}$

Even more contrary to accounts of racial harmony are the frequently mentioned incidents of racism and racial violence among servicemen during the Vietnam era. In the late 1960's and early 1970's, fights between white and black servicemen broke out in numerous locations around the globe. A July 1969 fight involving forty-four Marines at Camp Lejeune, North Carolina, resulted in injuries and the death of a white corporal. Between 1972 and 1973, race riots erupted aboard at least six Navy vessels, the worst being a melee on the aircraft carrier Kitty Hawk that left forty white sailors injured and

\footnotetext{
${ }^{32}$ Manny Garcia, An Accidental Soldier: Memoirs of a Mestizo in Vietnam (Alberquerque, NM: University of New Mexico Press, 2003), 123.

33 Lea Ybarra, ed., Vietnam Veteranos: Chicanos Recall the War (Austin, TX: University of Texas Press, 2004), 71; Charley Trujillo, Soldados: Chicanos in Vietnam (San Jose, CA: Chusma House Publishers, 1990), 125-126, 140.
} 
twenty-six black seamen under arrest. Most incidents of racial violence in the late Vietnam era, however, were small-scale events involving only a few individuals. Such episodes were especially prevalent in and around bars and other venues that served alcohol. ${ }^{34}$ One black memoirist, for instance, writes about his involvement in a bar brawl that started when a "glassy-eyed drunken" white GI called him a "nigger.",35

Not all racial unrest took place in bars or even between strangers, however, as some veterans portray their own units as smoldering powder kegs of racial enmity. Such accounts suggest that the need to cooperate during combat and the threat of military discipline only barely kept violence from breaking out between racial factions. One Chicano veteran says that the main reason the tense atmosphere that prevailed in his unit did not degenerate into violence was that each side in a potential racial conflict was "heavily armed." 36 A few memoirs include instances in which members of the same units came to blows over racial issues, such as a brawl that occurred when a white GI derisively called an Inuit soldier an "Indian.",37 One black memoirist threatened to shoot a white platoon-mate who uttered racial remarks; ${ }^{38}$ and another who spent several years as a prisoner of war, says that racial discord even plagued the Vietcong jungle camps that held American POWs. ${ }^{39}$

${ }^{34}$ Westheider, Fighting on Two Fronts, 94-113. For more on the Kitty Hawk riot, and racial unrest in the U.S. Navy during the war in general, see John Darrell Sherwood, Black Sailor, White Navy: Racial Unrest in the Fleet During the Vietnam War Era (New York: New York University Press, 2007).

${ }^{35}$ Ed Emanuel, Soul Patrol (New York: Ballantine Books, 2003), 244-245.

${ }^{36}$ Garcia, An Accidental Soldier, 101.

${ }^{37}$ Ibid.

${ }^{38}$ Whitmore and Weber, Memphis, Nam, Sweden, 52-53. 
Since blacks and whites were the main participants in the racial warfare that raged within the U.S. military, non-African-American minorities occupied an uncertain place in these conflicts. Most Native Americans and Mexican Americans expressed no solidarity or affiliation with either racial camp, but instead staked out neutral positions. ${ }^{40}$ One Mexican American told the blacks and whites in his platoon, who were constantly at odds, that he had "no shit with either ... race" and wanted to "stay out of it." Chicano, Juan Ramirez, explains that he was able to maintain neutrality because of his ambiguous racial identity: he was not black, but "not really white" either. Ramirez relates another story illustrating the racial ambiguity of Latino soldiers in Vietnam: one of Ramirez's white friends was incredulous that he was offended by the use of the word "nigger" to refer to black soldiers. The white soldier was puzzled by Ramirez's reaction because even though he was of Mexican heritage, the white GI saw him as a fellow white man. ${ }^{42}$ Although non-black minority groups mostly stayed out of black-white conflicts, they nevertheless fought their own racial battles. Several Mexican Americans say they and their compatriots fought with equal frequency against groups of whites, blacks, and Puerto Ricans. ${ }^{43}$

${ }^{39}$ James A. Daly and Lee Bergman, Black Prisoner of War: A Conscientious Objector's Vietnam Memoir (Lawrence, KS: University Press of Kansas, 2000), 107, 133, 148. Originally published as A Hero's Welcome: The Conscience of Sergeant James Daly Versus the U.S. Army (Indianapolis, IN: Bobbs-Merrill, 1975).

${ }^{40}$ Trujillo, Soldados, 111, 161-162; Juan Ramirez, A Patriot After All: The Story of a Chicano Vietnam Vet (Albuquerque, NM: University of New Mexico Press, 1999), 110-111.

${ }^{41}$ Trujillo, Soldados, 162.

42 Juan Ramirez, A Patriot After All, 111, 85.

${ }^{43}$ Ybarra, Vietnam Veteranos, 71; Trujillo, Soldados, 125-126, 140; Ramirez, A Patriot After All, 94. 
Also in contrast to accounts that stressed integration and racial harmony are those that suggest nonwhite soldiers had more in common with the Vietnamese than with their white comrades in arms. Some nonwhites came to realize that their skin tones and other physical features made them superficially similar to Vietnamese people. One AsianAmerican G.I. assigned to a burial detail was "overwhelmed" when it occurred to him that his fellow soldiers were all Caucasians, but the corpses all "looked like [him]."44 Others, such as a Chicano veteran who was told by a Vietnamese child that the two of them looked the "same," were made aware of these similarities by the Vietnamese. ${ }^{45}$ More often, nonwhite troops discovered, whether they agreed or not, that white soldiers thought they looked Vietnamese. Asian Americans were routinely called "gooks" by other GIs, ${ }^{46}$ and both Hispanics and soldiers of Asian heritage were occasionally mistaken for Vietcong by whites and nearly gunned down. One Hispanic GI, wounded so badly he appeared dead, was about to be thrown into a pile of enemy bodies when he heard someone exclaim: “That's no damn Gook. That's Sergeant Benavidez.",47

It was not necessary, however, for a minority soldier to resemble Vietnamese people to identify with them. A 1978 Veteran's Administration study found that almost 50 percent of surveyed black veterans held positive views of the Vietnamese, while a mere 9 percent held negative views. In contrast, over 30 percent of white veterans

${ }^{44}$ Carina A. Del Rosario, ed., A Different Battle: Stories of Asian Pacific American Veterans (Seattle, WA: Wing Luke Asian Museum, 1999), 60.

${ }^{45}$ Ybarra, Vietnam Veteranos, 69.

${ }^{46}$ Del Rosario, A Different Battle, 40, 48, 80, 103.

${ }^{47}$ Roy P. Benavidez and Oscar Griffin, The Three Wars of Roy Benavidez (San Antonio, TX: Corona Publishing Company, 1986), 4-5. 
answered negatively, and only 27 percent positively. ${ }^{48}$ African-American memoirs echo these findings, as many black veterans say they identified with the Vietnamese, not based on physical appearance, but on the perception that both groups were the victims of white racism and oppression. One Army veteran says that he "acquired a secret admiration for the Vietnamese people" because, like African Americans, they "were victims of social and economic inequality."49 Mexican Americans also identified with the Vietnamese based on shared socioeconomic background, as some saw their backgrounds as agricultural laborers reflected in the hardscrabble existence of South Vietnam's peasants. $^{50}$

One Chicano veteran says that when a fellow soldier was planning "to kill a little old lady for nothing," he silently decided: "If he shoots her, I'm going to shoot him."51 This act could have caused him to be ostracized or even killed, but the woman reminded him of "one of those little chenchas in the barrio"; he would at least make sure her killer paid for his crime. ${ }^{52}$ Accounts of American atrocities against civilians are not unique to minority narratives, but the story above highlights a difference between how whites and nonwhites depict these acts. Some minorities claim that nonwhite troops, because of their sensitivity to racism and frequent identification with the Vietnamese, never perpetrated war crimes. A Native American memoirist, for instance, says that the mistreatment of civilians was anathema to him because of the "old cruelties inflicted

\footnotetext{
${ }^{48}$ Arthur Egendorf, et al., Legacies of Vietnam: Comparative Adjustment of Veterans and Their Peers (Washington, D.C.: U.S. Government Printing Office, 1981), 392.

${ }^{49}$ Emmanuel, Soul Patrol, 130.

${ }^{50}$ Ybarra, Vietnam Veteranos, 41, 114.

51 Ibid., 42.

52 Ibid.
} 
upon American Indians at the hands of the U.S. Army." ${ }^{, 53}$ Conversely, many whites allegedly harbored a deep-seated racism that led them to commit heinous acts against the Vietnamese. A black author who saw white soldiers amuse themselves by luring Vietnamese children onto a busy highway asserts that "you never [saw] a soul [brother] doing anything like that.",54

The race-based identification with the Vietnamese expressed in many nonwhite narratives is reminiscent of the anti-war arguments espoused by Black Power figures in the latter years of the Vietnam conflict. Some in the Black Power Movement openly expressed solidarity for America's enemies, seeing the Vietcong and the North Vietnamese as allies in a worldwide struggle being waged by nonwhites against white imperialism. ${ }^{55}$ Stokely Carmichael, the outspoken Black Power leader, told the crowd at a 1967 anti-war rally that he saw "no reason for black men, who are daily murdered physically and mentally in this country, to go and kill yellow people abroad, who ... are, in fact, victims of the same oppression." ${ }^{, 56}$ Eager to exploit America's racial problems for propaganda purposes, the government of North Vietnam and its Vietcong allies seized upon these overtures from black militants. The North declared support for the Black Power movement and hosted visiting movement figures. Carmichael, for example, met with Ho Chi Minh, the president of North Vietnam, during a 1969 visit to Hanoi. ${ }^{57}$

\footnotetext{
53 Dwight W. Birdwell, A Hundred Miles of Bad Road: An Armored Cavalryman in Vietnam, 19671968 (Novato, CA: Presidio Press, 2000), 139.

54 David Parks, G.I. Diary, (New York: Harper and Row, 1968; reprint, Washington, DC: Howard University Press, 1984), 52.

${ }^{55}$ Van Deburg, New Day in Babylon, 99-100.

56 Joseph, Waiting, 180-181.

57 Ibid., 194.
} 
America's enemies also produced propaganda radio broadcasts and leaflets that beseeched black GIs in South Vietnam to stop fighting in the name of nonwhite solidarity. $^{58}$

These Black Power arguments evidently influenced the thinking of many AfricanAmerican troops, as more than half of the black GIs surveyed by Terry in 1969 saw the conflict in Vietnam as a "race war" between "whites and nonwhites." 59 Nevertheless, the great majority of nonwhite memoirs, even those produced by veterans who say they identified with the Vietnamese, do not contain any direct statements of support for the enemy. ${ }^{60}$ In fact, the idea that America's foes were the natural allies of nonwhite GIs is passionately denounced in the narratives of several black former POWs, who were probably subject to more racial propaganda than any other minority soldiers. Norman McDaniel, for instance, a black Air Force pilot who was captured by the North Vietnamese in 1966, told his captors that the U.S. was not "waging a war of genocide ... against dark-skinned people," as they claimed, but was "in Vietnam trying to help the South Vietnamese.",61

On the other hand, some narratives suggest that many nonwhite troops believed in, or were attracted to, some of the racial aspects of enemy propaganda. Perhaps the

\footnotetext{
${ }^{58}$ Westheider, Fighting on Two Fronts, 153-157.

${ }^{59}$ Terry, "Bringing the War Home," 8.

${ }^{60}$ The only minority memoir produced by a veteran who could be deemed an enemy sympathizer
} was Black Prisoner of War, by James Daly, an Army infantryman who was captured by the Vietcong in 1966. Daly became sympathetic to the cause of his captors, embraced Communism, and joined a group of anti-war POWs called the "Peace Committee" that issued condemnations against the war to the world media. Daly was charged with collaboration with the enemy by the U.S. government when he returned to the U.S., but was eventually acquitted.

${ }^{61}$ Wallace Terry, Bloods: An Oral History of the Vietnam War by Black Veterans (New York: Random House, 1984; Ballantine, 1985), 137. 
most commonly believed piece of propaganda was the Vietcong claim that their soldiers would try not to fire upon black troops. ${ }^{62}$ One veteran surmises that the reason a Vietcong guerrilla shot his lieutenant, but did not harm him, was nonwhite solidarity. He says, "The lieutenant was white. Charlie [the Vietcong] was yellow. I'm black." "63 Even a steadfastly patriotic former POW admits that Hanoi radio broadcasts about the "race situation" in the U.S. "made [him] and some of the other Negro prisoners think." ${ }^{64}$ The propaganda was unsuccessful, as none of these veterans defected or refused to fight, but revelations that it had widespread currency among nonwhite troops contributes to a negative portrayal of the war.

Besides a focus on racial cooperation and integration, another aspect of the positive version of the war is an emphasis on personal choice. One manifestation of this concept is the assertion by nonwhites that they, like many of their forebears who fought in earlier American conflicts, joined the military because they wanted to go to war. One black veteran was exempt from service in Vietnam but volunteered for combat duty anyway because he "wanted to see what the war was all about."65 Some Mexican Americans say they wanted to fight in Vietnam to prove their "machismo," or manliness. ${ }^{66}$ A majority of 170 Native-American veterans surveyed by the Veterans' Administration said they joined the military to continue "tribal and/or family traditions." This answer indicated, in the words of one historian, that many of the respondents

\footnotetext{
${ }^{62}$ Westheider, Fighting on Two Fronts, 156-157.

${ }^{63}$ Whitmore and Weber, Memphis, 71.

${ }^{64}$ James E. Jackson, Jr., “18 Months as a Prisoner of the Vietcong,” Ebony, August 1968, 118.

${ }^{65}$ Terry, Bloods, 63.

${ }^{66}$ Ybarra, Vietnam Veteranos, 40, 146.
} 
"actually wanted to participate in combat." 67 This attitude is expressed by a NativeAmerican memoirist who explains that the arrival of a draft notice was not a worrisome event because it was natural for him to follow "the warrior tradition" of his Arizona tribe. $^{68}$

Another manifestation of the concept of personal choice is the claim that nonwhite troops volunteered for the most dangerous combat roles in Vietnam, such as "point man" (the head of a combat patrol), machine gunner, or "radio man." Some memoirists proudly note that they personally held such roles during their tour, such as the former infantryman who loved to carry the powerful M-60 machine gun because his skill with it garnered the respect of his comrades. ${ }^{69}$ It is impossible to determine exactly how many of these dangerous positions were filled by nonwhites, but there is evidence that many minorities joined elite outfits that saw much combat during the war. Magazine and newspaper articles from the mid-1960's noted that the Army's all-volunteer airborne divisions contained large numbers of black troops, ${ }^{70}$ and separate studies found that inordinate numbers of Native Americans and Mexican Americans fought in elite, volunteer outfits. $^{71}$ Examples of participation in such groups can be found in a number of

\footnotetext{
${ }^{67}$ Holm, Strong Hearts, 19.
}

${ }^{68}$ Leroy TeCube, A Year in Nam: A Native American Soldier's Story (Lincoln, NB: University of Nebraska Press, 1999), xvi.

${ }^{69}$ Goff, Sanders, and Smith, Brothers, 67-70.

${ }^{70}$ The New York Times reported in January 1966 that "the all-volunteer $173^{\text {rd }}$ Airborne Division have as many as six Negroes among every 10 men." Apple, Jr., "Negro and White," 7. Later that year, Ebony reported that African Americans comprised "more than a third of the $101^{\text {st }}$ "s [Airborne Division] crack $1^{\text {st }}$ Brigade in Vietnam." "Birdmen with Black Rifles,' " Ebony, October 1966, 37.

${ }^{71}$ Holm, Strong Hearts, 19; Ralph Guzman, “Mexican American Casualties in Vietnam,” La Raza 1, no. $1,1971,12$. 
minority narratives, such as the Special Forces veteran who "volunteer[ed] for the toughest combat training they had" right after basic training. ${ }^{72}$

In contrast to this emphasis on individual choice, in the negative version of the war veterans assert that they did not want to fight in Vietnam, but were forced to for various reasons. Most of the minority veterans whose memoirs were analyzed came from poor or working-class households, a trait which made them, along with whites of similar socioeconomic backgrounds, "draft bait." Though every able-bodied American man could be drafted after he turned eighteen, middle- and upper-class men were better equipped than those of poorer backgrounds to take advantage of the various means available for avoiding the draft. The easiest and most common way was to get an educational deferment by enrolling in college, an option available to more Americans by the 1960 's than ever before, but still out of reach for most low income citizens. ${ }^{73}$ Minority narratives are full of stories of young men who were drafted after high school graduation because they could not afford college. Even those who volunteered for military service often did so only because they were sure that a draft notice would soon arrive in the mailbox anyway. Such was the case for a black veteran who, after losing his educational deferment when financial problems ended his first semester in college, "joined the Army so [he] could get a choice."74

\footnotetext{
${ }^{72}$ Terry, Bloods, 237-238.

${ }^{73}$ Lawrence M. Baskir and William A. Strauss, Chance and Circumstance: The Draft, the War, and the Vietnam Generation (New York: Alfred A. Knopf, 1978; Vintage, 1978), 8-11, 28-52.

${ }^{74}$ Terry, Bloods, 18
} 
Half of the black enlisted men surveyed by Terry believed that "blacks [were] assigned more dangerous duty than whites. ${ }^{, 75}$ Many memoirists express wholehearted agreement with this charge. Such veterans contend that the actions of racist white officers were behind the large numbers of minorities in hazardous combat roles. More minorities than whites were supposedly ordered to carry the M-60 machine gun, a weapon whose effectiveness and distinctive sound made it a prime target for enemy gunners, or to act as "forward observers," small groups that ventured outside the relative safety of base camps to watch for enemy activity. A few veterans, such as a black memoirist who was informed he had been made a forward observer by a maliciously smiling sergeant, say that the racist motives behind the assignment of dangerous jobs were often all too evident. ${ }^{76}$

Another feature of the negative version was the claim that minorities were overrepresented in Vietnam in general or, more commonly, just in combat units. One Chicano memoirist alleges that whites were the minority in infantry units, ${ }^{77}$ and a black Army veteran says "black soldiers became a majority ... of the fighting force" in Vietnam. ${ }^{78}$ One memoirist noticed that Army infantry units were seemingly comprised of an inordinate number of black soldiers, and while still in Vietnam, obtained casualty statistics that supported his observations. ${ }^{79}$ Even veterans who do not claim they

\footnotetext{
${ }^{75}$ Terry, "Bringing the War Home," 12.

${ }^{76}$ Parks, G.I. Diary, 76.

${ }^{77}$ Garcia, Accidental Soldier, 42.

${ }^{78}$ Emmanuel, Soul Patrol, 125.

${ }^{79}$ Fenton A. Williams, Just Before the Dawn: A Doctor's Experiences in Vietnam (New York: Exposition Press, 1971), 114. Williams was able to obtain casualty records because he served in Vietnam as doctor in an Army hospital.
} 
observed minority overrepresentation firsthand still maintain that it existed, and some, like a former GI who states that Puerto Rican troops suffered a " 25 to 35 percent" casualty rate, offer statistics (usually unsubstantiated) to support their assertions. ${ }^{80}$

Even if some of these claims are exaggerated, they nonetheless basically reflect an important reality: African Americans and other nonwhite groups saw combat in numbers out of proportion to their respective percentages of the U.S. population. The disproportionate sacrifice of African American troops is evident in their casualty rates. Almost a quarter of American troops killed in Vietnam in 1965, essentially the first year of the ground war for U.S. troops, were black. Due to the Pentagon's efforts to reduce the number of black casualties, as well as other factors, the casualty rate for blacks eventually fell to more normal levels; although it took until 1968 for this to be achieved. 81

In the Vietnam era, U.S. military personnel were placed in one of five racial categories: Caucasian, Negro, American Indian, Mongolian, or Malayan. ${ }^{82}$ Unfortunately, this outdated and imprecise classification system makes it possible to accurately determine the casualty rate for only one other nonwhite group besides African Americans: Native Americans. In an inverse of the situation for blacks, Native-American

${ }^{80}$ Santoli, Everything We Had, 161

${ }^{81}$ Westheider, Fighting on Two Fronts, 12-13. Besides the Pentagon's conscious efforts to lessen the presence of blacks on the frontlines, the reduction of the African American death rate was also partly due to changes in American military strategy implemented in the war's later stages. During this period, U.S. forces in Vietnam shifted their focus from ground combat to airpower. Since far more black servicemen were involved in ground combat than the air war, fewer African-American troops were in Vietnam after the strategy shift occurred.

${ }^{82}$ Racial category list is from the United States National Archives and Records Administration, Combat Area Casualties Current File (CACCF). Obtained online at http://www.archives.gov/research/vietnam-war/casualty-statistics.html. There was also a sixth racial category: "Unknown or Not Reported." 
soldiers did not suffer a disproportionate overall casualty rate, ${ }^{83}$ but they were overrepresented in Vietnam. ${ }^{84}$ Mexican Americans and Puerto Ricans also probably fought in disproportionate numbers, but the classification system caused Latinos to be lumped into one of the other three categories. The author of a 1971 study, however, concluded that "Mexican American military personnel have a higher death rate in Vietnam than all other servicemen" because a high percentage of casualties from southwestern states had Spanish surnames. ${ }^{85}$

The idea that nonwhites served in much greater numbers than their percentage of the U.S. population would warrant in itself presents a negative image of racial conditions in Vietnam, but the negative impression is even more pronounced in some memoirists' explanations of why overrepresentation occurred. African-American leaders had criticized the high casualty rate for black troops early in the war, but in the late 1960's, Black Power activists offered a new critique of this phenomenon. These more militant voices alleged that the overrepresentation of blacks in Vietnam was evidence of a genocidal "federally sponsored" plot to wipe out the "cream of black youth." 86 This charge, of course, was false. The disproportionate presence of nonwhites in combat was primarily an unintended consequence of military manpower allocation policies. Soldiers in the Vietnam era were assigned to military occupations based on how well they did on the Armed Forces Quotient Test (AFQT), an evaluation similar to civilian "IQ" tests.

\footnotetext{
${ }^{83}$ Native Americans comprised 1.4 percent of the U.S. population in the Vietnam era, and approximately .4 percent of American soldiers killed in Vietnam. United States National Archives and Records Administration, Combat Area Casualties Current File (CACCF). Obtained online at http://www.archives.gov/research/vietnam-war/casualty-statistics.html.

${ }^{84}$ Holm, Strong Hearts, 11.

${ }^{85}$ Guzman, "Mexican American Casualties in Vietnam," 12.

${ }^{86}$ Van Deburg, New Day in Babylon, 100.
} 
Due mostly to educational disadvantages, nonwhites generally performed worse than whites on the AFQT, and since low scorers were usually channeled into combat training, an inordinate number of minorities ended up on the frontlines. ${ }^{87}$

Even if the Black Power explanation was incorrect, several memoirs nonetheless suggest that belief in this conspiracy theory was widespread among black GIs during the Vietnam era. One veteran learned in basic training that many of his fellow AfricanAmerican recruits believed "blacks were being drafted for genocidal purposes." 88 Another African-American memoirist, Ed Emmanuel, apparently believed in the theory himself, since he calls the presence of large numbers of black soldiers in combat an example of "institutionalized genocide." ${ }^{\prime 9}$ By expressing belief in this idea, Emmanuel rejects the idea that individuals' personal decisions were the main reason for the outsize presence of black soldiers in combat. This is ironic because Emmanuel served in an allvolunteer Army reconnaissance unit that undertook dangerous missions deep into enemy territory. The title of his memoir, Soul Patrol, was a reference to the nickname given to his platoon, which was composed entirely of African Americans who had volunteered to fight. ${ }^{90}$ The contradictions between Emmanuel's claims of genocide and the nature of his service in Vietnam is a prime example of how aspects of the positive and negative versions of the war can co-exist in the same narrative.

\footnotetext{
${ }^{87}$ Westheider, Fighting on Two Fronts, 4, 12-14, 37; Scholar Tom Holm also surmised that Native Americans were disproportionately involved in combat because substandard educations caused them to generally do poorly on the AFQT. (Holm, Strong Hearts, 10, 19).

${ }^{88}$ Goff, Sanders, and Smith, Brothers, 11.

${ }^{89}$ Emanuel, Soul Patrol, 58.

${ }^{90}$ Ibid., 86-87
} 
The final feature of the positive, more traditional depiction of the war is expression of pride in the fighting abilities of one's own race. Samuel Vance states that the focus of his memoir, published in 1970 while the war was still going on, is "the Negro in Vietnam and his ability to wage war and lead men in battle." ${ }^{91}$ Throughout the book, titled The Courageous and the Proud, Vance gives many examples of how African-American soldiers demonstrated their ability to be capable leaders and fighters in Vietnam. He suggests that this stellar performance proves black Americans deserve full rights in the U.S. Several other African-American narratives include similar statements of pride. Emmanuel, for instance, says that he learned during his combat tour that African Americans "were inherently superior warriors" whose "raw physical agility" could not be matched by soldiers of other races. ${ }^{92}$

Boasts about the fighting prowess of one's own racial or ethnic group are also common in the accounts of veterans who belonged to other nonwhite groups. Mexican Americans proudly assert that the men of $L a R a z a$ were the best and bravest soldiers in Vietnam, always eager to fight and willing to take on any challenge, no matter how daunting. One veteran, for instance, maintains that he "never saw a Chicano ... back off---never---not once," and adds that Mexican Americans were always ready to volunteer for the most hazardous duties on the battlefield. ${ }^{93}$ Some Native-American veterans allege that they were assigned to the most dangerous roles on the battlefield because their superiors assumed that "Indians" were natural warriors. Many Native

\footnotetext{
${ }^{91}$ Vance, The Courageous, 9.

${ }^{92}$ Emmanuel, Soul Patrol, 129.

${ }^{93}$ Trujillo, Soldados, 128.
} 
Americans did not appreciate this stereotype. ${ }^{94}$ Yet one memoirist proudly states that his Native-American heritage made him inherently skilled in the ways of war, and for that reason he always chose to be the point man of a combat patrol. ${ }^{95}$

The nonwhite portrayal of the war is always complicated, and even expressions of racial pride often contained negative elements. This is the case with African Americans who attest to the battlefield prowess of black soldiers, but also denigrate the fighting skills of whites. A black Army veteran says that he discovered in Vietnam that whites were less "tough" and "more cowardly than [he] expected."96 Even Vance, who promotes the power of integrated military service to break down racial barriers, proudly contends that black soldiers never shirked their duty or passed up the chance to fight, but "white boys" supposedly often faked illnesses to avoid combat. ${ }^{97}$ This combination of racial pride and anti-white sentiment was apparently shared by many African Americans during the Black Power era. A majority of blacks polled by Newsweek in 1969 said they "saw the war as evidence that Negroes make better combat soldiers than whites." 98 Nor was this attitude confined to African-American veterans. Some Mexican Americans claim that, while their people showed great courage on the battlefield in Vietnam, whites and blacks often reacted in combat in a cowardly fashion. ${ }^{99}$

${ }^{94}$ Holm, Strong Hearts, 151-152.

95 Delano Cummings, Moon Dash Warrior: The Story of an American Indian in Vietnam, A Marine from the Land of the Lumbee (Livermore, Maine: Signal Tree Publications, 1998, 2001), 6, 37, $54,75$.

${ }^{96}$ Terry, Bloods, 23.

${ }^{97}$ Vance, The Courageous, 76, 101, 133.

${ }^{98}$ Peter Goldman, Report From Black America (New York: Simon and Schuster, 1970).

${ }^{99}$ Trujillo, Soldados, 80, 128, 157. 
Literary scholar Susan Jeffords argues that "a prominent motif of Vietnam films, personal narratives, [and] novels" is that the shared experience of combat led to "the eradication of social, class, ethnic, and racial boundaries" in American military units. ${ }^{100}$ Another scholar contends that white authors (many of whom were veterans) of Vietnam War novels employ this theme so extensively that the soldiers in their books are "deracialized"; all have been made part of a brotherhood of "grunts" that ignores racial and ethnic distinctions. ${ }^{101}$ There are a few instances in which white veterans emphasize these themes in their narratives, such as Frederick Downs' description of his diverse platoon in The Killing Zone. The problem with white narratives, however, is not how they portray racial issues, but that most do not mention racial issues at all. Consequently, readers learn from white memoirs something much worse than the idea that racial harmony was the rule in Vietnam: the narratives reinforce the false notion that race was not an important factor in the history of the war.

Race was an important aspect of the war, but the absence of this topic from white narratives is surely unintentional. Presumably, most white memoirists either did not recall any racial issues that arose during their tours, or did not consider such topics worthy of inclusion in their narratives. A veteran's narrative is not an objective or comprehensive history of the war; it is an account of one person's experiences in that war. Such a limited perspective guarantees that some issues will not receive proper attention. The problem is that the white perspective of these issues is not counterbalanced with differing viewpoints because relatively few narratives by nonwhites

${ }^{100}$ Susan Jeffords, The Remasculinization of America: Gender and the Vietnam War (Bloomington, IN: Indiana University Press, 1989), 54.

${ }^{101}$ Beavers, “Contemporary Afro-American Studies," 9-13. 
were published. Analysis of these minority memoirs confirms the importance of differing viewpoints, as it shows that nonwhite accounts represent a valuable countermemory of the war that puts race in the forefront.

The race-centric depiction of the war that nonwhites offer reflects the complicated nature of how minority groups dealt with the war. Two primary versions of the war vied for control in nonwhite communities, a positive, more traditionally based version, and a negative version characterized by antipathy to the war and adherence to some aspects of Black Power ideology. The negative overtook the positive in the minds of most minorities by the end of the war, but the narratives show that, for veterans at least, competition between these two ideas never ceased, even after the war was over. The continuance of this struggle is demonstrated by the nonwhite veterans who include conflicting, sometimes contradictory statements about the war in their memoirs. For many nonwhite veterans, "Vietnam" symbolized both racial cooperation and pride in service, and white racism, racial conflict, even suspected genocide.

Clark Smith, the co-author of one of the first African-American veteran memoirs, Brothers: Black Soldiers in the Nam, writes in the book's introduction that "Brothers is an attempt to give the black Vietnam veteran a voice in the history of the Vietnam War." ${ }^{102}$ In 1982, the year Brothers was published, the voice of African-American veterans was virtually absent from the nation's collective memory of the war. Since that time, the African-American experience in Vietnam has received more attention in popular culture and scholarship, but still not nearly as much as it deserves. The overdue assessment for other nonwhite veterans is even worse, since their stories have only been covered in a handful of obscure oral histories and scholarly studies. This chapter

\footnotetext{
${ }^{102}$ Goff, Sanders, and Smith, Brothers, xii.
} 
hopefully not only adds to the understanding of the experiences of nonwhite veterans, but also shows the need for more attention to this neglected topic. 


\section{CHAPTER FIVE \\ MEN, WOMEN, AND VIETNAM}

During Michael Lee Lanning's tour in Vietnam, he assiduously kept a journal of his daily activities as an Army officer in charge of infantry units. Years later, he converted this record into two memoirs, The Only War We Had: A Platoon Leader's Journal of Vietnam, ${ }^{1}$ and Vietnam, 1969-1970: A Company Commander's Journal. ${ }^{2}$ These books are about the lives of infantry "grunts" in "the Nam," men who for a year inhabited a world in which they mostly interacted with other men, be they friend or foe. But women, too, played a part in Lanning's Vietnam experience. Married only a few months before deployment to Southeast Asia, he thought constantly about his wife Linda, especially after learning she was pregnant with their son. Linda is a periodic presence in his books, but so too are Vietnamese prostitutes and bar girls. ${ }^{3}$ Though Lanning does not participate himself, he cheerfully abets the sexual exploits of his men, allowing their construction of a temporary brothel, ${ }^{4}$ and laughing along when one "grabbed a mini-

\footnotetext{
${ }^{1}$ Michael Lee Lanning, The Only War We Had: A Platoon Leader's Journal of Vietnam (New York: Ivy Books, 1987), 5, 11-12, 38

${ }^{2}$ Michael Lee Lanning, Vietnam, 1969-1970: A Company Commander's Journal (Ballantine Books, 1988, College Station, TX: Texas A\&M University Press, 2007).

3 Ibid., 5, 11-12, 38-39, 47-48.

${ }^{4}$ Ibid., 232-233.
} 
skirted waitress and threw her on top of the table" during a drunken night on the town. ${ }^{5}$ He also joins in the ridicule of female American Red Cross workers, whose supposed lack of sexual attractiveness was said to "improve" after extended months away from "round-eyed" women. ${ }^{6}$ Not all encounters with women in these books, however, are lighthearted. Lanning once ordered the body of a female Vietcong leader to be displayed "half-naked" in a public square.

Lanning's memoirs are not unique; women appear throughout veterans' narratives as wives, Red Cross workers, Asian bar girls, enemy soldiers, and in other occupations and situations. Strangely, though, scholars have written little on the portrayal of women and male-female interactions in these accounts. As is the case with scholarly treatment of veterans' narratives in general, the great majority of writers who have dealt with the portrayal of gender-related issues have conflated these works into analyses of novels, films, and other fictional material. ${ }^{8}$ Most of these scholars, moreover, have neglected to look at the portrayal of women and sexual issues in favor of analyzing how Vietnam War fiction and nonfiction deal with issues related to masculinity. In her well-known cultural history, The Remasculinization of America: Gender and the Vietnam War, Susan Jeffords writes much about the relationship between concepts of masculinity and popular culture treatments of the war, but women play little part in her analysis. She argues, for instance, that soldiers "shared" women as a means of reinforcing the cohesion of their units, but

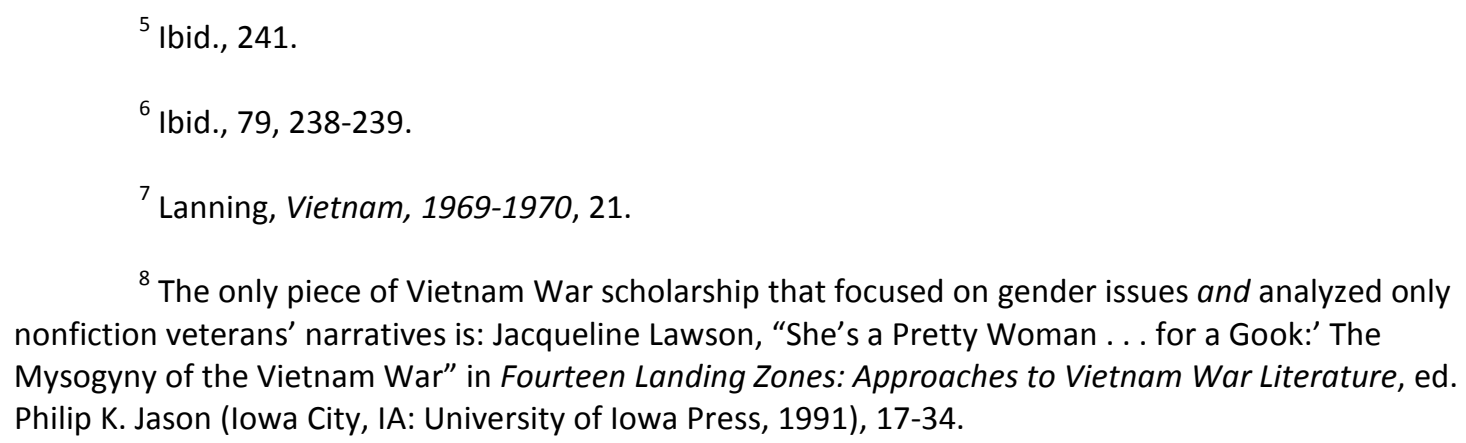


writes comparatively little about the women being shared. ${ }^{9}$ Historians, for their part, have paid little attention to the interactions between men and women in Vietnam, relegating such issues to the margin. This is a major oversight, since these interactions were an important part of the experiences of American veterans, and were a significant aspect of the history of the war in general.

To fully address these important gender issues, it is necessary to consider what happened, why it happened, and how it was portrayed, and to incorporate the perspectives of women as well as men into the story. The information about what happened between men and women in Vietnam, and why, is provided by the veterans' memoirs and additional supporting primary and secondary sources. The veterans indicate that a generally sexist and misogynist attitude animated U.S. troops in their interactions with members of the opposite sex, including Vietnamese women, nurses and other American women in Vietnam, and women they encountered on Rest and Recuperation ("R\&R") trips to Asian countries. The memoirs and supplemental sources show that the primary reasons for this behavior were rooted in aspects of military and mainstream culture that promoted hostility towards women and the belief that sex is the right of every soldier during wartime. Women of all types were viewed in this way, but racial stereotypes common among GIs meant that the intensity of these attitudes was heightened when they dealt with Asian women.

Though the memories of soldiers who served in Vietnam are invaluable resources for learning what happened there and why, they are nonetheless fallible and subjective in how they portray the past. For this reason, it is equally important to analyze how

\footnotetext{
${ }^{9}$ Susan Jeffords, The Remasculinization of America: Gender and the Vietnam War (Bloomington, IN: Indiana University Press, 1989), 41.
} 
memoirists depicted what happened. By making light of or romanticizing situations in which GIs displayed sexist, misogynistic, or racist attitudes or behavior, many veterans showed that at the time they recalled these events, usually years after the war had ended, they still approved of them. Women were often depicted in ways that mirrored these attitudes: Asian women as submissive, American women as domineering, any woman in a war zone as an object of sexual gratification, and so forth.

Though the attitudes and experiences of veterans were not monolithic, the perspectives they offer are inherently limited because all but a few memoirists are men. It is for this reason that the narratives of American and Vietnamese women are necessary to provide a different perspective, or "counter-memory," just as the minority narratives in chapter three offer a counter-memory in regards to racial issues. These women experienced many of the same events as the men, and their recollections often support those of their male counterparts. Specifically, the same sexist attitudes and behavior that male veterans recalled as having characterized male-female interactions in Vietnam were reported by women as well. As the victims of this behavior, however, women obviously experienced it very differently, and their portrayals stand in sharp contrast to the laudatory depictions offered by the men.

Sex is a common element in veterans' narratives, and most mentions of sex involve prostitution. In recalling their impressions as newcomers to South Vietnam, memoirists invariably list the same few things: sweltering heat and noxious smells, the poverty of the local people, the filthiness of their surroundings, and the visibility of the sex trade. Saigon and dozens of smaller cities teemed with bars, massage parlors, and 
brothels that catered to GIs looking to spend their coveted U.S. dollars on alcohol and sexual pleasure. The refugee shantytowns made of cardboard and flattened beer cans that so often lay on the outskirts of American military bases invariably featured shabby bordellos known as "boom-boom houses." 10 If a soldier could not make it to a brothel, the prostitutes might come to him; veterans claim that women selling their bodies had the uncanny ability to appear wherever there were U.S. troops, even during combat operations. A former officer, for instance, said that he caught one of his men having sex with a prostitute only minutes after his company had established a perimeter around a village. $^{11}$

Even if some of these stories are exaggerated, the veterans accurately assessed wartime South Vietnam as a society plagued by prostitution. By late 1965, less than a year after the start of major U.S. ground operations, Saigon's fashionable Tu Do Street had already been transformed into a thriving red-light district. ${ }^{12}$ In 1966, U.S. Senator J. W. Fulbright was criticized by the White House for his description of Saigon as "literally ... an American brothel,"13 and the U.S. ambassador to South Vietnam warned that libidinous GIs were alienating America's allies. ${ }^{14}$ Other cities were affected as well, such as Pleiku, which saw an influx of 8,000 to 10,000 "bar girls" (essentially a euphemism

\footnotetext{
${ }^{10}$ Philip Caputo, A Rumor of War, New York: Holt, Rinehart and Winston, 1977; Owl Books, 1996), 107-108.

${ }^{11}$ Robert Hemphill, Platoon, Bravo Company (Fredericksburg, VA: Sergeant Kirkland's Press, 1998; St. Martin's Paperbacks, 2001), 39-41.

${ }^{12}$ R.W. Apple Jr., “Lodge Worried Over Behavior of G.I.'s in Saigon," The New York Times, 13 August 1966, 3.

${ }^{13}$ E.W. Kenworthy, "Fulbright Issues a Warning to U.S.," The New York Times, 6 May 1966, 2.

${ }^{14}$ Apple Jr., "Lodge Worried," 3.
} 
for prostitute) when U.S. troops were first allowed within its limits in $1968 .{ }^{15}$ South Vietnamese politicians endlessly debated how best to deal with the prostitution explosion; Vietnamese women's groups assailed the comparatively wealthy Americans for luring girls into the sex trade, ${ }^{16}$ and ordinary Vietnamese complained in letters to newspapers about the problem. ${ }^{17}$ In 1977, four years after U.S. troops had left Vietnam, a Catholic nun charged with rehabilitating prostitutes by the new Communist government estimated that 300,000 prostitutes worked in South Vietnam, 60,000 in Saigon alone. ${ }^{18}$

It is no mystery why South Vietnam was inundated with prostitutes during the American occupation. Women engaged in the sex trade have followed armies since the beginning of warfare, and when a nation's economy is ravaged by war, women are often forced to sell themselves to survive. Many of the reasons why so many American soldiers patronized prostitutes in Vietnam are also as old as war itself. Young men are perhaps more inclined to pay for sex when they are far away from home, often for the first time, removed from the social constraints of their home communities. Living in an all-male society that encourages members to prove their masculinity may also be a factor, and when a soldier faces death and injury every day, moral and legal restrictions on prostitution may seem pointless. One need only look to the behavior of American troops in World War II to understand that the actions of GIs in Vietnam were far from

\footnotetext{
${ }^{15}$ Bernard Weinraub, "Pleiku, Open to G.I.'s, Is Problem City," The New York Times, 12 August $1968,3$.

${ }^{16}$ Jonathan Randal, "Red-Light Limits Opposed in Saigon," The New York Times, 14 November 1966, 13.

${ }^{17}$ Nu-Anh Tran, "South Vietnamese Identity, American Intervention, and the Newspaper Chinh Luan," Journal of Vietnamese Studies 1, no. 1-2 (February 2006): 179, 186-190.

18 “Hanoi Asks Nun to Rehabilitate Ex-Prostitutes," The New York Times, 6 February 1977, L9.
} 
extraordinary. The bordellos of North Africa, Italy, France, and numerous other locales around the globe were full of U.S. troops during the 1940's. ${ }^{19}$

Many veterans' narratives suggest, however, that another reason lay behind the widespread use of prostitutes in Vietnam: the tendency of officers at all levels to tolerate, even encourage such activities. A number of memoirs include stories of low-level officers who accepted prostitution, and several memoirists who were officers admit to condoning or engaging in such behavior themselves. The best example of this comes from About Face, the memoir of David Hackworth, a career Army officer who served in Vietnam and became famous for excoriating the military's war strategy during a 1971 television interview. ${ }^{20}$ Hackworth admits that he periodically organized trips for his men to a bordello called "Madame Nhu's House of Pleasure" when they needed to "let off some steam." ${ }^{21}$ He sympathized with the sexual needs of his troops because he remembered that as a combat soldier in the Korean War "you were always horny and never discriminating; you weren't looking for love, you were looking for pussy."22

Several veterans go a step further in their claims about tolerance for prostitution, claiming that the U.S. military operated its own brothels in Vietnam. One veteran, for instance, writes that the Army operated a collection of "whorehouses" near An Khe that were "built ... for soldiers to go relieve themselves." 23 Such claims may seem to be

${ }^{19}$ Charles Winick and Paul M. Kinsie, The Lively Commerce: Prostitution in the United States (Chicago: Quadrangle Books, 1971), 246, 258-260.

${ }^{20}$ David H. Hackworth and Julie Sherman, About Face (New York: Simon and Schuster, 1989), 771-783.

\footnotetext{
${ }^{21}$ Ibid., 132.

22 Ibid., 132
} 
exaggerations, repeated rumors, or even falsehoods, but they are nevertheless based in fact. Though it was officially illegal for servicemen to pay for sex, the military nevertheless oversaw at least two "semiofficial bordellos" near Pleiku and An Khe. ${ }^{24}$ A 1966 Time article explained that the An Khe brothel, a twenty-five acre complex nicknamed "Disneyland" by soldiers, was owned by Vietnamese, but U.S. military police "patrol[ed] the compound and check[ed] the pass of each GI entering." ${ }^{25}$ In order to control the spread of venereal disease, its workers were required to make a weekly visit to a clinic "for a medical examination ... and a U.S.-provided shot of a long-lasting penicillin-type drug., 26

Most narrated sexual encounters with prostitutes took place in Vietnam, but many memoirists also write about paying for sex during Rest and Recuperation ("R\&R") trips to other Asian nations. In an effort to boost morale, every American soldier was allowed a week-long excursion to one of ten destinations (most of them in East Asia) during his or her one-year tour in Vietnam. ${ }^{27}$ Some soldiers spent R\&R with their wives, girlfriends, or relatives in Honolulu, ${ }^{28}$ but every other city was dominated by single soldiers

\footnotetext{
${ }^{23}$ Wallace Terry, Bloods: An Oral History of the Vietnam War (New York: Random House, 1984; Ballantine, 1991), 25-26.

${ }^{24}$ Randal, "Red-Light Limits," The New York Times, 13. Journalist Susan Brownmiller names Lai Khe as a third location for a U.S. military brothel, but all other sources, including veterans' narratives, only mention the installations at Pleiku and An Khe. Susan Brownmiller, Against Our Will: Men, Women, and Rape (New York: Fawcett Columbine, 1975), 93-95.

25 “Disneyland East,” Time, 6 May 1966.

${ }^{26}$ Ibid.

27 “Five-Day Bonanza," Time, 22 December, 1967. The ten R\&R cities were Hong Kong, Bangkok, Honolulu, Tokyo, Taipei, Singapore, Manila, Penang, Kuala Lumpur, and Sydney.

${ }^{28}$ Charles H. Turner, "When Johnny Comes Marching to Hawaii on R\&R," The New York Times, 21 March 1971, XX1.
} 
interested, according to one memoirist, in only two things: "drinking and fucking."29 According to most narratives, buying sex was the primary activity of GIs during their week away from Vietnam, and numerous veterans unabashedly said they slept with prostitutes during their trips. Many soldiers chose a city solely for the rumored attributes of its sex trade, and they swapped information about how to find the cheapest brothels and the most attractive women, or "where the girls performed the best tricks." 30

Several veterans recalled that military authorities approached $R \& R$ prostitution in the same tolerant way it dealt with prostitution in Vietnam. One memoirist writes that he and other new arrivals were briefed at the beginning of their trip by an officer who offered tips on how not "to catch something" when paying for sex. ${ }^{31}$ Similar stories appear in other narratives, and in 1968, The New York Times reported that the " $\mathrm{R}$ and $\mathrm{R}$ center" in Taipei took "a realistic attitude" by offering a brochure which warned of diseases and instructed GIs on how to avoid paying too much for sex. ${ }^{32}$ As in Vietnam, the military did not just tolerate the illegal activities of soldiers, but also indirectly facilitated their search for sex. In Bangkok, the tourist agency contracted by the U.S. military to handle R\&R travel plans booked soldiers in hotels that provided a female companion for " $\$ 25$ a night or the flat rate of $\$ 125$ for a seven-day week." 33 Two

\footnotetext{
${ }^{29}$ Robert Mason, Chickenhawk (New York: Viking, 1983; Penguin, 2005), 325.

${ }^{30}$ Tim O'Brien, If I Die in A Combat Zone, Box Me Up and Ship Me Home (New York: Delacorte Press, 1973; Delta, 1989), 101.

${ }^{31}$ Tracy Kidder, My Detachment: A Memoir (New York: Random House, 2005), 116-117

${ }^{32}$ Sidney Gruson, " 'R and R' Tours on Taiwan: American Servicemen Bring a Mixed Blessing to the Island," The New York Times, 14 February 1968, 6.

${ }^{33}$ Stuart H. Loory, Defeated: Inside America's Military Machine (New York: Random House, 1973), 225-226.
} 
memoirists who stayed in such accommodations both write of choosing "girlfriends" from lineups of numbered women at "girl markets" located in hotel lobbies. ${ }^{34}$

The ostensible reason for the military's lenient attitude towards prostitution was that it was part of a practical approach towards controlling the spread of venereal disease. Military commanders decided that if they could not stop soldiers from paying for sex they could at least regulate their access to prostitutes. This situation was wholly in keeping with how the U.S. military dealt with the sex trade throughout much of the twentieth century. During both world wars, the U.S. government, determined to keep the nation's fighting men away from prostitutes, passed tough laws that effectively shut down the sex trade in America for the duration of those conflicts. Military commanders overseas, however, often found it nearly impossible to enforce the ban on prostitution, especially when troops were stationed in countries where prostitution was legal. Many commanders reacted to this situation by quietly regulating prostitution, believing this to be the most practical way to prevent outbreaks of "VD." Semi-official brothels staffed by U.S. military policemen who kept order and made sure GIs used nearby “prophylactic stations," sprung up all over Europe and Asia during World War II. ${ }^{35}$ In Japan, Thailand, and other nations occupied by American troops in the postwar years, unofficial acceptance and regulation of prostitution continued unabated into the Vietnam era and beyond. $^{36}$

\footnotetext{
${ }^{34}$ Charles R. Anderson, Vietnam: The Other War (Novato, CA: Presidio Press, 1982), 175-182; Mason, Chickenhawk, 325-328.

${ }^{35}$ Winick and Kinsie, The Lively Commerce, 247-259.

${ }^{36}$ Loory, Defeated, 216-230.
} 
While the desire to prevent the spread of venereal disease was surely a primary motive, a less acknowledged reason for this attitude was the belief that "men at war required the sexual use of women's bodies." ${ }^{37}$ This attitude can be seen in Hackworth's excursions to the local bordello and in other accounts of officers who allowed or encouraged their men to pay for sex. The narratives of American women in Vietnam offer numerous accounts of this behavior as seen from an outsider's perspective. Women recall "obscene" USO shows that featured scantily-clad women, ${ }^{38}$ rows of pornographic magazines for sale in the PX, and exotic dancers performing at officers' clubs. ${ }^{39}$ One former Army nurse witnessed, to her great embarrassment, the standard lecture about VD, condoms, and "clean" women given to troops at the beginning of R\&R. ${ }^{40}$

Media coverage of soldiers on R\&R and Vietnam's bargirls shows that this idea was not restricted to the military, but was widely accepted in American society. Mainstream periodical articles about the sexual behaviors of troops in Vietnam "blithely quoted the going rates for prostitutes, ${ }^{41}$ and often featured photographs of soldiers cavorting with foreign women. Articles were often written in a wry tone, and employed phrases such as "perfumed professionals" 42 and "leggy blonde."43 This style of writing

\footnotetext{
${ }^{37}$ Brownmiller, Against Our Will, 93-94.
}

${ }^{38}$ Kathryn Marshall, In the Combat Zone: An Oral History of American Women in Vietnam, 19661975 (Boston: Little, Brown, 1987), 76.

${ }^{39}$ Mary Reynolds Powell, $A$ World of Hurt: Between Innocence and Arrogance in Vietnam (Cleveland, OH: Greenleaf Enterprises, 2000), 145.

${ }^{40}$ Winnie Smith, American Daughter Gone to War: On the Frontlines with an Army Nurse in Vietnam (New York: William and Morrow, 1992; Pocket Books, 1994), 223-224.

${ }^{41}$ Christian G. Appy, Working-Class War: American Combat Soldiers and Vietnam (Chapel Hill, NC: University of North Carolina Press, 1993), 237. 
and reporting conveyed the feeling that buying sex, at least for soldiers, was a perfectly acceptable and understandable practice. Further evidence of the currency of this attitude during the Vietnam era was Senator Fulbright's subsequent apology for his controversial "brothel" comment. In clarifying his remarks, the senator said that he was not "maligning the brave young Americans in Vietnam," but warning the nation of the impact GIs "behaving in the way that is to be expected of men at war" might have on a "fragile Asian society." 44

This attitude was not only prevalent in the military and the media during the war, it was also evident in how veterans' memoirs portray prostitution. Memoirs often contain extended anecdotes about prostitution that serve as humorous breaks in books otherwise dominated by descriptions of death and destruction. One veteran writes about a clueless commanding officer who gave his men "permission" to substitute masturbation for trips to the local brothel. ${ }^{45}$ Another tells the story of a hapless GI who "contracted something" from a prostitute in Okinawa. ${ }^{46}$ Memoirs, which often feature sections of reconstructed dialogue, frequently contain exchanges in which soldiers joke and brag about their encounters with prostitutes and other sexual exploits. The humorous way in which the memoirist often frames these stories sometimes makes it seem as if the veteran author is

42 “Cleaning Up Saigon,” Time, 1 December 1969.

${ }^{43}$ Robert Trumbull, "For R and R, It's Australia First, Last, Always," The New York Times, 10 January 1969, 10.

44 “Fulbright Declares He Regrets Charge of U.S. 'Arrogance,' " The New York Times, 18 May 1966, 8.

${ }^{45}$ Mason, Chickenhawk, 234-235.

${ }^{46}$ Richard E. Ogden, Green Knight, Red Mourning (New York: Zebra, 1985; Pinnacle Books, 2002), 118. 
encouraging his male readers to participate vicariously in these moments of soldierly camaraderie.

The jocular tone of these stories indicates that years after the war ended, veterans believed, like so many soldiers and civilians in the Vietnam era, that visiting prostitutes was a normal activity for fighting men. Other than a few exceptions, the closest veterans come to criticizing prostitution is expressing dissatisfaction with their personal experiences with buying sex. Such memoirists were disgusted by the filthiness of brothels, disliked the physical appearance of a prostitute, or felt angry when women turned out to be unenthusiastic "duds" who did not feign interest in their clients. ${ }^{47}$ Almost no one criticizes prostitution because of its deleterious effects on society and the lives of sex workers, or says he believes it to be a generally immoral practice. ${ }^{48}$ Often there is a tinge of nostalgia in veterans' accounts of their youthful sexual exploits in Vietnam. Some memoirists, like the former soldier who felt "like a king" during R\&R because his paid companion was "a beautiful broad," openly proclaim their fondness for those days. $^{49}$

Encounters with prostitutes are often described in graphic, near-pornographic detail. Part of this is probably a manifestation of the trend among Vietnam veterans to eschew self-censorship in telling their stories, as well as the new willingness of

\footnotetext{
${ }^{47}$ Anderson, Vietnam, 182.
}

${ }^{48}$ The lone exception was Donald Duncan, a former Green Beret who wrote the first published Vietnam-veteran memoir, The New Legions. Duncan became disillusioned with the war and the military while in Vietnam, and became an active participant in the anti-war movement after he returned to the United States. He presents the negative effects of the sex trade on Vietnamese society as one of many reasons why U.S. involvement in Vietnam is wrong. The New Legions (New York: Random House, 1967), 224-225.

\footnotetext{
${ }^{49}$ Mark Baker, Nam: The Vietnam War in the Words of the Soldiers Who Fought There (New York: William and Morrow, 1981; Berkley Books, 1983), 137.
} 
publishers to print material once considered unfit for distribution. ${ }^{50}$ It is obvious, though, that much of the time veterans describe sex in such explicit detail for the purpose of entertaining and titillating their male readers. This motive is most evident in memoirs that describe the $R \& R$ experience as a trip to a sort of sexual fantasyland, with descriptions of the sexual encounters that occurred there used to enhance this depiction. Perhaps veterans or their publishers felt compelled to include explicit sexual content in memoirs out of the assumption that films and novels had led consumers to expect Vietnam War stories to feature sex. Just as likely, though, this is another manifestation of the memoirists' inclination to romanticize wartime sex with prostitutes and frame such behavior as a natural pursuit of men at war.

Though most of the sexual encounters in personal narratives are brief and businesslike, some veterans report that they established (or at least tried to establish) legitimate romantic relationships with Asian women during their tours. A few fell for "regular girls," such as the two who pursued women who worked on American bases, ${ }^{51}$ or another who dated a student in an English language class he taught. ${ }^{52}$ Some write derisively of lonely GIs who naively fell in love with prostitutes, ${ }^{53}$ but others claim they formed real relationships with women they met in brothels. One such veteran became

${ }^{50}$ Samuel Hynes, The Soldiers' Tale: Bearing Witness to Modern War (New York: Penguin 1997), 181.

${ }^{51}$ Tobias Wolff, In Pharoah's Army: Memories of the Lost War (New York: Alfred A. Knopf, 1994), 30-35; Charles R. Anderson, The Grunts (San Rafael, CA: Presidio Press, 1976), 82-107.

52 William Broyles, Jr., Brothers in Arms: A Journey from War to Peace (New York: Alfred A. Knopf, 1986), 206-207.

53 Michael Norman, for instance wrote in his memoir, These Good Men about Jim, a "naïve and vulnerable man" in his unit who married a bar girl while in Thailand during R\&R. Jim really loved the girl, but Norman believed she was most likely using the marriage as a means to get to America. Michael Norman, These Good Men: Friendships Forged from War (New York: Crown Publshers, 1989), $151-152$. 
engaged to a prostitute during his R\&R trip to Malaysia, and even signed on for an extra year of service in Thailand because it kept him relatively close to his fiancée. ${ }^{54}$ Another veteran seriously considered deserting the Army to stay in Taiwan with a woman he "rented" during his R\&R trip to Singapore. ${ }^{55}$

Such relationships were beset by a host of obstacles, but over 8,000 Americans nevertheless returned to the U.S. with Vietnamese "war brides." U.S. servicemen also married women from Thailand and other Asian nations during the Vietnam era. ${ }^{56}$ It is possible that some of these couples met during R\&R excursions. The great majority of these relationships, however, ended when a soldier left Vietnam at the end of his tour, if not before. The more than 70,000 children of American fathers living in South Vietnam at war's end is one indicator of a great number of failed wartime relationships. Some of these were undoubtedly the unplanned children of prostitutes, but others were the products of seemingly loving relationships that abruptly ended when their fathers returned to America. ${ }^{57}$ No memoirists say that they fathered children in Vietnam, but all those who claim to have fallen in love during their tours eventually left their girlfriends behind when they returned to the U.S. One former officer vowed he would find a way to

54 John Ketwig, And a Hard Rain Fell: A G.I.'s True Story of the War in Vietnam (New York: Macmillian, 1985), 110-112, 117, 130.

${ }^{55}$ Stanley Goff, Robert Sanders, and Clark Smith, Brothers: Black Soldiers in the Nam (Novato, CA: Presdio Press, 1982), 184-189.

${ }^{56}$ U.S. Commissioner of Immigration and Naturalization, Annual Reports, 1947-75 in Bok-Lim Kim, "Asian Wives of U.S. Servicemen: Women in the Shadows" Amerasia 4, no.1 (1977): 99.

${ }^{57}$ Robert S. McKelvey, The Dust of Life: America's Children Abandoned in Vietnam (Seattle: University of Washington Press, 1999, 3-4, 44-45. Most of the Vietnamese mothers of Amerasian children surveyed in a U.S. government study conducted in the early 1990's, indicated that their relationships with the fathers of their children were "more than transitory affairs or 'one night stands.'" (45) The majority of women said they lived with, and were financially supported by their American lovers, and "nearly 63 percent expected to join the father after he first left Vietnam." (45) 
stay with his girlfriend after his tour ended, but in the end he took the "freedom bird" back to the United States without even telling her goodbye. ${ }^{58}$

These stories of doomed love affairs show that even women who were part of "loving" relationships were often treated by GIs in much the same way they treated prostitutes, as sexual objects that could be thrown away when convenient. One probable reason for this behavior was the sexual mores of mid-twentieth century America.

Although the Vietnam War took place at the same time as the Sexual Revolution was underway back home in the U.S., a traditional double standard in sexual matters was still very much in place during this period. Pre-marital sexual behavior became progressively more common in the United States after the 1920's, a majority of men in the post-World War II era still wanted to marry virgins. ${ }^{59}$ In earlier times, men solved this paradox by visiting prostitutes. ${ }^{60}$ But in the twentieth century, most men satisfied their premarital sexual urges by dividing women into two categories: "bad girls" and "good girls." "Bad girls" had sex, and for this reason were acceptable "to play with," but when it came to time for marriage, men looked for a chaste good girl who was more of the "marrying type." Typically a "bad girl" was someone a man saw as beneath him, sometimes because she was of a lower social class, but often just because her willingness to have sex supposedly indicated immorality. ${ }^{61}$ Coming from this cultural background, it is no

\footnotetext{
${ }^{58}$ Broyles, Brothers in Arms, 206-207.
}

59 John D'Emilio and Estelle B. Freedman, Intimate Matters: A History of Sexuality in America (New York: Harper and Row, 1998), 256-265; See also Beth Bailey, Sex in the Heartland (Cambridge, MA: Harvard University Press, 1999), 117-120.

${ }^{60}$ Alfred C. Kinsey, Wardell B. Pomeroy, and Clyde E. Martin, Sexual Behavior in the Human Male (Philadelphia: W.B. Saunders Company, 1948), 597-609.

${ }^{61}$ D’Emilio and Freedman, Intimate Matters, 256-265; See also Bailey, Sex in the Heartland, 117120. 
wonder that GIs showed little respect for the women, prostitutes or not, with whom they had sex during the war.

Racial attitudes played a significant role in shaping these attitudes toward Asian women. According to veterans' narratives, most soldiers saw "love-making with a Vietnamese as a higher form of masturbation," ${ }^{\circ 2}$ and they regarded all Asian women as essentially unattractive substitutes for American females. One veteran explains that the most common means employed by soldiers to satisfy their sexual urges was to "stare at an underfed, prematurely aged, Vietnamese woman and fantasize her into Raquel Welch."63 Statements such as "good-looking for a Vietnamese," woman ... for a gook," are common. ${ }^{65}$ When GIs encountered an attractive Asian woman they usually assumed she was biracial, such as a Vietnamese girl soldiers quoted in one memoir believed must have been "half French" because she was "too fine to be all gook.",66

Just as race was a factor in the behavior of GIs towards Asian women, the depiction of these women in veterans' memoirs is also marked by racism. In most memoirs, Vietnamese and other Asians of any sex or age are rendered essentially as scenery, or maybe props with which American soldiers interacted; and are hardly ever afforded more than a strictly peripheral role in the story. This racist portrayal particularly applies to Asian prostitutes, who are usually depicted as voiceless, faceless nonentities

\footnotetext{
${ }^{62}$ Duncan, The New Legions, 225.

${ }^{63}$ Anderson, Vietnam, 136.

${ }^{64}$ Frederick Downs, The Killing Zone: My Life in the Vietnam War (New York: Norton, 1978), 82.

${ }^{65}$ O’Brien, If I Die, 110.

${ }^{66}$ Johnnie M. Clark, Guns Up! (New York: Ballantine Books, 1984; 2002), 199.
} 
referred to only as "the whore," or "the girl." The only Vietnamese prostitutes referred to by name are those who were given crude nicknames by American troops, such as "Madame Fred," "Slash,",67 or "Butch."68 In the rare instances in which prostitutes are quoted, their lines are invariably composed of broken English, GI slang, and obscene propositions to potential customers.

Like some nonfiction narratives, many Vietnam War novels contain stories of love affairs between Asian women and American soldiers. In most of these works, the female love interest is portrayed as a typical western stereotype of an Asian woman: meek, submissive, and interested only in serving the needs of her man. ${ }^{69}$ This manner of depiction also basically applies to love interests in memoirs, except that the personalities of the real-life women are even more muted. The relatively few veterans who became involved in legitimate relationships during their tours in Vietnam offer very little information about their love interests. The reader never learns the names of most of these girls (one is just called "this woman"), ${ }^{70}$ and one veteran apparently knew the girlfriend he met on R\&R only as "Suzanne," the obviously fictional western name she used with American customers. ${ }^{71}$ Very much like the Asian love interests in novels, these women are depicted as having "no real life before" they met their American lovers, "and none

\footnotetext{
${ }^{67}$ Alfred S. Bradford, Some Even Volunteered: The First Wolfhounds Pacify Vietnam (Westport, CT: Praeger Publishing, 1994), 60-61.

${ }^{68}$ Nathaniel Tripp, Father, Soldier, Son: Memoir of a Platoon Leader in Vietnam (South Royalton, Vermont: Steerforth Press, 1996), 192.

${ }^{69}$ Kali Tal, "The Mind at War: Images of Women in Vietnam Novels by Combat Veterans" Contemporary Literature 31, no.1 (Spring 1990): 77, 80-85.

${ }^{70}$ Al Santoli, Everything We Had: An Oral History of the Vietnam War by Thirty-Three American Soldiers Who Fought It (New York: Random House, 1981; Ballantine, 1983), 59-61.

${ }^{71}$ Goff, Sanders, and Smith, Brothers, 184-189.
} 
that is pursued after" he leaves. ${ }^{72}$ It is telling that the only wartime lover described in any narrative as strong, independent, or intelligent, is a white European woman a memoirist met during R\&R in Hong Kong. ${ }^{73}$

A different perspective on wartime relationships between Americans and Asian women is clearly needed, and there is no better source for this than When Heaven and Earth Changed Places, the memoir of Le Ly Hayslip, a Vietnamese woman who grew up during what her people called the "American War." As a young girl, Hayslip was forced to flee in shame to Saigon after she was seduced and impregnated by a wealthy employer. Many poor girls in Saigon survived by working as bar girls or prostitutes, and others acquired American boyfriends who paid their living expenses. Hayslip initially refused to follow this path, but she eventually decided that moving to the United States was her son's only chance at a good life; and to immigrate she needed an American husband. Though Hayslip eventually married a civilian contractor, a kind and caring man who brought her to the U.S. in 1970, she first suffered through three disastrous relationships with American men. The first tried to convince her to work as a topless dancer to impress his friends; the second was deported after he almost strangled her to death in a drunken rage; and the third, though he promised never to abandon her, abruptly returned by himself to the U.S. without warning. ${ }^{74}$

Not all the sexual encounters between Vietnamese women and American men were consensual. Military records show that more than fifty American servicemen were

${ }^{72}$ Tal, "The Mind at War," 77.

${ }^{73}$ W.D. Ehrhart, Vietnam-Perkasie: A Combat Marine Memoir (Jefferson, NC: McFarland, 1983; reprint, Amherst, MA: University of Massachusetts Press, 1995), 157-171.

${ }^{74}$ Le Ly Hayslip and Jay Wurts, When Heaven and Earth Changed Places (New York: Doubleday, 1989), 168-169, 173-174, 224-227, 255, 262, 274-284, 279-302, 323-325. 
convicted of rape, "rape and assault," attempted rape, and other related crimes in Vietnam. The actual number is certainly higher than the official figures because it is likely that the great majority of such crimes were never reported. ${ }^{75}$ A precise accounting of such atrocities may not be possible, but many veterans' memoirs suggest that they were not uncommon occurrences. As one scholar correctly notes, these accounts "are replete with . . . acts of rape, gang rape, assaults on women, torture, mutilation, and murder." ${ }^{76}$ One veteran saw a woman tortured to death by a group of Green Berets, ${ }^{77}$ and another witnessed "women put to torture as having Coca-Cola bottles run up their womb." $" 78$ Even narratives that do not feature such crimes sometimes include stories of rapes and related atrocities that almost happened. One former Marine, for example, says he prevented the gang rape of a Vietnamese woman by two members of his platoon. ${ }^{79}$

The rape of Vietnamese women by American soldiers is also a common element in films and print fiction about the war. Some scholars argued that rape is often glorified or trivialized in these mediums, ${ }^{80}$ but this is never the case with nonfiction narratives. The lighthearted tone memoirists use to describe nearly every other type of sexual encounter is entirely absent from accounts of rape. Some report on these acts without comment, while others express horror and outrage. The few individuals who stopped rapes are obviously proud that they took a stand to stop what they thought were immoral

${ }^{75}$ Brownmiller, Against Our Will, 97-101.

${ }^{76}$ Lawson, "She's a Pretty Woman," 19.

${ }^{77}$ Ketwig, And a Hard Rain, 70-73.

${ }^{78}$ Terry, Bloods, 256.

${ }^{79}$ Clark, Guns Up!, 199-201.

${ }^{80}$ Tal, "The Mind at War," 82-84; Karen Stuhldreher, "State Rape: Representations of Rape in Vietnam," Vietnam Generation 5, no. 1-4 (1994): 155-158. 
acts. It would appear that unlike patronizing prostitutes, or even harassing women, rape did not fall within the limits of acceptable behavior for American fighting men in Vietnam.

Some accounts of atrocities committed against women do nonetheless lead to a negative and stereotypical, if inadvertent, portrayal of Asian women because the victims (or near victims) were female fighters. Women did indeed serve as guerrilla soldiers in the struggle against the United States, and the leadership of the Vietcong propagandized the existence of these "long-haired warriors." ${ }^{81}$ It is significant, then, that these women who were held up by their leaders as examples of feminine strength, only appear in veterans' memoirs as wounded and abused, or dead and defiled. Such was the case with the female sniper whose corpse was stripped naked and thrown into a fire, ${ }^{82}$ or accounts of captured Vietcong guerrillas who were nearly gang-raped. ${ }^{83}$ Though they represented some of the bravest women in Vietnamese society, these soldiers invariably appear in veterans' memoirs as stereotypically weak and helpless Asian women. It is not the veterans' fault that the only time they came into contact with these women they were in such degraded situations, but the fact remains that narrative readers see female fighters only in this context.

The other females that appeared in the world of the GI serving in Vietnam were non-Asian women, mostly Americans, referred to almost universally as "round eyes" or

${ }^{81}$ See Sandra C. Taylor, Vietnamese Women at War: Fighting for Ho Chi Minh and the Revolution (Lawrence, KS: University Press of Kansas, 1999), 38, 61, 71, 87-89, and Karen Gottschang Turner with Phan Thanh Hao, Even the Women Must Fight: Memories of War from North Vietnam (New York: John Wiley and Sons Inc., 1998), 20-23, 33.

${ }^{82}$ Matthew Brennan, Brennan's War: Vietnam 1965-69 (Novato, CA: Presidio Press, 1985), 48.

${ }^{83}$ Clark, Guns Up!, 201; David Donovan, Once a Warrior King: Memories of an Officer in Vietnam (New York: McGraw-Hill, 1985), 218. 
"round-eyed women." Whereas Asians were described as generally unattractive, nonAsian females were held up as the epitome of beauty. ${ }^{84}$ Many narratives make it seem as if every GI in Vietnam was obsessed with non-Asian females and nearly driven mad by their scarcity. On the rare occasions that soldiers were able to see such women in person, for example at USO shows that featured "ripe American beauties" 85 as entertainers, it was a cause for celebration. Even an injury was seen as somewhat of a blessing if it meant a brief stay in a hospital staffed by female U.S. military nurses. Sydney, Australia was a popular R\&R destination for GIs because women from Asian countries made up only a small percentage of the population. ${ }^{86}$ One veteran explains that when given the choice between Hong Kong and Sydney, he chose the latter city because he wanted to "see something with round eyes," not "slant eyes." 87 These sentiments echo the words of an Army helicopter pilot who told a Time reporter in 1967 that he enjoyed his visit "down under" because it "was great just to see white girls with round eyes again.",

Referring to women as "round eyes" is, of course, the height of objectification, and the narratives show that most GIs judged the worth of American women in Vietnam solely on their physical characteristics. Women considered attractive were ogled and

\footnotetext{
${ }^{84}$ All references to "round eyes" appearing in the most-prominent memoirs and oral histories are apparently made by white Gls about Caucasian women. This term is not used in any of the few nonwhiteauthored narratives in this primary group, and it appears only once in the many less-prominent nonwhite memoirs analyzed in Chapter 4. Delano Cummings, a Native-American veteran, says in his memoir that both whites and blacks in his platoon referred to a "half-black" Vietnamese girl they encountered as a "round eye." Delano Cummings, Moon Dash Warrior: The Story of an American Indian in Vietnam, a Marine from the Land of the Lumbee (Livermore, Maine: Signal Tree, 1998), 99.

${ }^{85}$ Ehrhart, Vietnam-Perkasie, 51.

${ }^{86}$ Trumbull, "For R and R, It's Australia First," 10.

${ }^{87}$ Baker, Nam, 136.

88 “Five Day Bonanza," Time.
} 
lusted over, but those who did not live up to soldiers' idea of round-eyed beauty were ridiculed or dismissed as unworthy of attention. The two types of American women that appear most frequently in memoirs, military nurses and Red Cross volunteers known as "Donut Dollies," were frequent targets of this kind of behavior. GIs joked that Donut Dollies were "invariably homely" and overweight. 89 The troops consequently gave these women such demeaning nicknames as "Blue Blimps" $" 90$ and "Biscuit Bitches."91 One memoirist writes of the time he and some comrades resorted to crude behavior to cause a group of army nurses to flee a bar in disgust; the men disapproved of the nurses' presence because they were either "elderly" or "very plump." 92 On top of the abuse nurses and Donut Dollies received for their alleged lack of physical beauty, two veterans, ironically, claim that these women sometimes worked as prostitutes. ${ }^{93}$

Most veterans portray the GI obsession with "round-eyed women" as an amusing quirk, and episodes in which soldiers harassed or ridiculed nurses and Donut Dollies as moments of harmless fun. These depictions show the need for a different perspective, or a "counter memory," and luckily, there exist accounts from American women about what it was like to be a "round-eye" in Vietnam. While these women express great affection for the soldiers they entertained or cared for, most also say it was infuriating to be the

${ }^{89}$ Ehrhart, Vietnam-Perkasie, 81.

${ }^{90}$ Bradford, Some Even Volunteered, 108-109.

${ }^{91}$ Lanning, The Only War, 239.

92 Mason, Chickenhawk, 340.

${ }^{93}$ Veteran Alfred Bradford says in his memoir that he met a Donut Dolly who bragged that she charged an American general $\$ 5,000$ for sex, and hoped to make $\$ 100,000$ from prostitution before she left Vietnam. Bradford, Some Even Volunteered, 108. Another memoirist, Johnnie M. Clark, claims that he paid a Red Cross volunteer for sex during his tour, and that this woman also said she planned to make thousands of dollars as a prostitute while in Vietnam. Clark, Guns Up!, 216-223. 
constant center of attention and treated as an "object of curiosity." "94 American women who walked down the street in Vietnam were invariably barraged with the stares, whistles, and catcalls of dozens of GIs. ${ }^{95}$ One former Army nurse says that servicemen, often complete strangers, propositioned her for sex innumerable times during her tour in Vietnam. ${ }^{96}$ Another nurse became "fed up" at being "treated like a piece of meat at the market."97 Though no women memoirists admit they were raped in Vietnam, one former Donut Dolly was groped by a group of soldiers who believed the rumors that all Red Cross workers were "loose women" who were willing to trade sexual favors for cash. ${ }^{98}$

Nurses, Donut Dollies, and other American women in Vietnam are almost never more than peripheral figures in veterans' memoirs, but another group of American women, wives and girlfriends left behind in the U.S., play an even smaller role. Veterans' memoirs are concerned mostly with their authors' tours in Vietnam. Consequently, women back home remain mostly unseen: they send letters and figure in lonely soldiers' reminiscences of their prewar lives, but that is usually all. GIs saw Vietnam as such a faraway, alien, almost surreal place that they called the United States "The World," as if it were another planet. ${ }^{99}$ Combat troops, who experienced death and destruction on a daily basis, felt especially alienated from the comparatively cushy existence of civilians in the U.S. Therefore, it is perhaps accurate for these documents to

${ }^{94}$ Powell, $A$ World of Hurt, 12.

${ }^{95}$ Smith, American Daughter, 14.

${ }^{96}$ Lynn Hampton, The Fighting Strength: Memoirs of a Combat Nurse in Vietnam (Canton, $\mathrm{OH}$ : Daring Books, 1990; reprint, New York: Warner Books, 1992), 14, 86.

${ }^{97}$ Smith, American Daughter, 81.

${ }^{98}$ Marshall, In the Combat Zone, 68-72.

${ }^{99}$ Appy, Working-Class War, 250. 
portray people back in "The World," men and women alike, as remote and inconsequential to the experiences of troops in Southeast Asia.

Numerous narratives included memories of basic training, virtually all of which centered on the verbal abuse heaped upon recruits by their drill instructors. A favorite "D.I." tactic was to tell recruits that their "sweethearts" were "whores" who were sleeping with other men. One veteran summed up the view of women pounded into the heads of trainees by their drill instructors as: "Women are villains. They are creatures akin to Communists and yellow-skinned people and hippies." ${ }^{100}$ In light of such indoctrination, it is perhaps not surprising that the few instances in which women back home became the center of attention in narratives is when they commit acts of betrayal. Several veterans wrote of heartless wives or girlfriends who authored so-called "Dear John" letters, which informed soldiers that their romantic relationships were over. One memoirist explains that combat soldiers, men who faced death on a daily basis and saw comrades killed and maimed in battle, regarded the arrival of such a letter as the worst thing that could befall a GI in Vietnam. ${ }^{101}$ Soldiers typically experienced profound grief when they received a Dear John letter, and sometimes exhibited deep anger towards the women they believed had abandoned and betrayed them. Such was the case with a veteran who says that after reading such a letter he called his former girlfriend a "bitch" and a "whore," and even vowed to kill her if he made it home alive. ${ }^{102}$

\footnotetext{
${ }^{100}$ O'Brien, If I Die, 44.

${ }^{101}$ Broyles, Brothers in Arms, 145.

${ }^{102}$ Ehrhart, Vietnam-Perkasie, 131-136.
} 
William Broyles, Jr., a onetime Marine Corps officer and Vietnam veteran, wrote in his memoir, Brothers in Arms: A Journey from War to Peace, of the strange effects war has on human sexuality:

Most men who have been to war, and most women who have been around it, remember that never in their lives was their sexuality so palpable. War cloaks men in a costume that conceals the limit and inadequacies of their separate natures. It gives them an aura, a collective power, an almost animal force.

War heightens all appetites. I cannot describe the ache for candy, for taste; I wanted a Mars bar more than I wanted anything in my life. And that hunger paled beside the force that pushed us toward women, any woman. Even the homeliest women floated into our fantasies and lodged there. Too often, we made our fantasies real, always to be disappointed, our hunger only greater. ${ }^{103}$

In many ways, veterans' narratives portray service in Vietnam as very much a masculine experience: groups of men fighting other men, proving their manhood, and forming deep bonds with each other. The hunger for sex that Broyles writes about, however, along with the never-ending quest to satiate that hunger, is so prominent in veterans' narratives that women are never really absent from accounts of tours in "the Nam." The women most often used by GIs to fulfill their sexual appetites in Vietnam, Asian prostitutes and girlfriends, frequently appear in memoirs for this reason, but it is also behind the inclusion of other types of women. "Round-eyed" nurses and Donut Dollies usually do not appear as sexual partners in narratives, but they are nevertheless present because they were evaluated by soldiers based on their sexual attractiveness.

Despite the prevalence of sex and women in veterans' memoirs, few scholars have written about these topics. This is a great oversight, as these documents are valuable primary sources for learning about how American soldiers in Vietnam viewed and interacted with women. Analysis of these documents shows that, overall, soldiers'

\footnotetext{
${ }^{103}$ Broyles, Brothers in Arms, 205-206.
} 
attitudes towards women were sexist, misogynist, and, in regards to Asian women, racist. Coupled with information from secondary sources, analysis also shows that these attitudes were largely the products of military and mainstream American culture. Just as important as what happened and why is how these issues were portrayed, and for the most part, veterans' portrayals, no matter when they were recorded, indicate an adherence to the sexist and racist attitudes of the Vietnam era. The portrayal of these issues is important because it is the lens through which readers learn about them. And since published Vietnam War narratives are dominated by male American veterans, it is their perspective that reaches the widest audience. This perspective is undoubtedly valuable, but the narratives of Vietnamese and American women show the pitfalls that exist in relying on just one side of the story when trying to understand the past. 


\section{CHAPTER SIX \\ THE RETURN HOME AND LIFE AFTER VIETNAM}

During the year that Lynda Van Devanter, author of the memoir, Home Before Morning: The Story of an Army Nurse in Vietnam, spent working in a U.S. Army hospital in Pleiku, South Vietnam, she witnessed scenes of unspeakable carnage almost every day. The task of tending to the constant stream of hideously wounded American soldiers and Vietnamese who passed through the hospital gradually destroyed her former self, an idealistic young woman eager to serve her country, and replaced it with a cynical, bitter, and emotionally exhausted veteran. Thoroughly disillusioned with the war, her country's leaders, and the values that had led her to join the military, Van Devanter was overjoyed when her tour in Vietnam ended in June, 1970 and she got to go home. ${ }^{1}$ When the plane taking her and other military personnel back to the United States finally took off, she and other passengers exuberantly shouted, "Vietnam sucks!!," and then "there was laughter and hugging and tears."2 They "were the lucky ones," as Van Devanter saw it, who "had made it out alive."

\footnotetext{
${ }^{1}$ Lynda Van Devanter with Christopher Morgan, Home Before Morning: The Story of an Army Nurse in Vietnam (New York: Beaufort Books, 1983), 1-208.

2 Ibid., 208.

${ }^{3}$ Ibid.
} 
Van Devanter adds, however, that not long after this outburst of joy, "a vague uneasiness" fell over her and the other veterans as they started to wonder, "what [they] would face back in the real world." ${ }^{4}$ She learned soon after her plane landed in California that this uneasiness was justified. Van Devanter needed to get to San Francisco International Airport to catch a flight to her hometown, but the Army bus would only take her as far as the Oakland Army Terminal. Finding no public transportation available, she decided to hitchhike the twenty or so miles to San Francisco. Because she had hitchhiked numerous times in Vietnam, she saw no problem in trying to "thumb" a ride on an American highway. Van Devanter, however, dubiously claims that numerous passing motorists, instead of picking her up, shouted obscenities, made vulgar gestures, and threw trash at her. The drivers, she claims, were enraged at the sight of her uniform. Eventually someone pulled over: two men in a Volkswagen bus, the driver sporting long hair, wire-rimmed glasses, and a "peace sign" T-shirt. ${ }^{5}$ The unkempt man offered Van Devanter a ride, but when she approached the bus she discovered the real reason he had stopped:

But the guy slammed the door shut. "We're going past the airport, sucker, but we don't take Army pigs." He spit on me. I was stunned.

"Fuck you, Nazi bitch," the driver yelled. He floored the accelerator and they both laughed uncontrollably as the VW spun its wheels for a few seconds, throwing stones back at me before it roared away. The drivers of other passing cars also laughed.

I looked down on my chest. On top of my nametag sat a big gob of brownishcolored saliva. I couldn't touch it, but I didn't have the energy to wipe it away.

\footnotetext{
${ }^{4}$ Ibid.

${ }^{5}$ Ibid., 209-210.
} 
Instead, I watched as it ran down my name tag and over a button before it was absorbed into the green material of my uniform. ${ }^{6}$

Van Devanter eventually made it back home, but due to emotional and psychological problems related to the trauma of her war experiences, her homecoming troubles continued. Plagued by nightmares and depression, and feeling alienated from family and friends, she spiraled out of control into a life of alcoholism and "one-night stands." During those years of despair, she admits that she "thought a lot about suicide," but "always chickened out" when it was time to follow through on her "perfectly organized" plans to kill herself. ${ }^{8}$ Van Devanter eventually married, her depression and the frequency of her nightmares subsided, but the "emptiness" she brought back from Vietnam still "lurked in a dark corner of [her] soul.",

In the final pages of Home Before Morning, Van Devanter says that she finally got on the path to healing her psychological wounds after becoming involved with the Vietnam Veterans of America (VVA). Attending VVA meetings and talking with other veterans made her feel better, and soon after joining the group she founded the VVA's Women Veterans' Project, an initiative to raise public awareness of female veterans. At the book's end, Van Devanter is enrolled in college, on her way to a psychology degree, and her work with the VVA has led to the Veterans' Administration recognizing women veterans for the first time. These successes, coupled with an eye-opening return trip to

\footnotetext{
${ }^{6}$ Ibid., 211.

${ }^{7}$ Ibid., 220-286.

${ }^{8}$ Ibid., 249.

${ }^{9}$ Ibid., 272-274.
} 
Vietnam, lead her to proclaim that even though the war left a permanent scar on her psyche, "the emptiness is gone now."10

Though Home Before Morning is primarily concerned with Van Devanter's wartime experiences, a large portion of the book is devoted to her post-Vietnam life. The content of Van Devanter's memoir is far from atypical. Many Vietnam veteran memoirists included much information about their post-Vietnam experiences in their books, and in some of these works, the author's life after returning home is more important than his or her war stories. A few veteran-writers covered their wartime experiences in a first memoir, then released one or two subsequent books dealing with their postwar experiences. Veterans who added their stories to oral histories also often spoke of their lives after Vietnam. The final two chapters of the 1981oral history compilation, Nam: The Vietnam War in the Words of the Men and Women Who Fought There, contain only veterans' homecoming stories and accounts of re-entry into civilian life. $^{11}$

This focus on the postwar lives of Vietnam veterans typifies how the war has been remembered in the United States. From the late 1960's onward, journalists, academics, politicians, filmmakers, and other opinion makers directed much attention to what happened to Vietnam veterans after they came home. As the war further receded into history, the story of the Vietnam veteran became increasingly prominent in the nation's collective memory, with the conflict they fought in becoming almost secondary in importance. In 1978, Hollywood ended its longtime avoidance of the war by releasing

\footnotetext{
${ }^{10}$ Ibid., 303.

${ }^{11}$ Mark Baker, Nam: The Vietnam War in the Words of the Soldiers Who Fought There (New York: William and Morrow, 1981; Berkley Books, 1983), 239-296.
} 
two high-profile "Vietnam movies," Coming Home and The Deer Hunter, ${ }^{12}$ both of which focused mostly on the readjustment problems of returning soldiers and relatively little on the war itself. By the time the Vietnam Veterans' Memorial was dedicated on the National Mall in 1982, many Americans were probably more familiar with stories of allegedly spat-on soldiers and psychologically disturbed veterans than the My Lai Massacre or the Tet Offensive.

Home Before Morning is not only typical of veterans' memoirs because it includes much information on Van Devanter's post-Vietnam experiences, but also because many aspects of her experiences are also commonly found in other veterans' narratives. Many veterans say that they were disrespected and insulted by anti-war protestors and the general public when they returned home. Numerous others admit to suffering from nightmares and "flashbacks," using alcohol and drugs to dull their pain, and having difficulties interacting with loved ones. Finally, a number of veterans say they eventually overcame their readjustment problems and made successful lives for themselves, often doing so with the help of fellow veterans. These aspects can be consolidated into three primary themes: painful homecoming, struggles with psychological problems and readjustment to civilian life, and eventual healing and hope for the future. In many narratives, as in Home Before Morning, these themes appear chronologically in the order outlined above, and in some cases, they play out over the course of multiple memoirs produced by one veteran.

The depiction of the postwar lives of Vietnam veterans offered in Home Before Morning and so many other memoirs, however, are, in several ways, inaccurate and misleading. First, these accounts incorrectly assert that anti-war activists and the

\footnotetext{
${ }^{12}$ Peter Biskind, "The Vietnam Oscars," Vanity Fair, March 2008, 266.
} 
American public in general reviled and abused returning service personnel. Stories of spat-upon veterans and other homecoming horror stories have also appeared in popular culture and political rhetoric since the 1970's, and in recent years, scholars have questioned the veracity of these claims. It is likely that the memories of most, if not all, of the memoirists who say that they were spat-on and harassed when they came home were warped by years of films and other cultural products that featured these largely mythic events.

Another problem with veterans' memoirs is that they do not provide the accurate historical context needed to compare Vietnam veterans' experiences with those of veterans of earlier wars. Veterans commonly suggest that their postwar troubles were unique, since participants in previous American wars, especially World War II, were supposedly welcomed home as heroes and suffered from few readjustment problems. Historical scholarship and other sources reveal, however, that veterans from previous American wars often did not have positive homecomings, and that warriors have returned from the battlefield with psychological wounds for thousands of years.

Finally, the third common theme in veterans' reminiscences of their postwar lives, that they eventually overcame their readjustment problems and succeeded in the personal, educational, and occupational arenas, is also misleading. It is true that the great majority of Vietnam veterans, even those who encountered initial problems, successfully reentered civilian life and became productive, well-adjusted citizens. In a sense, however, veteran memoirists were too successful: some of the most popular authors became famous or wealthy before or after their books were published; an inordinate number earned post-graduate degrees after the war; and few indicated that at the time their books 
were published they were currently experiencing significant problems. The successes of these authors distracted readers from the many Vietnam veterans who struggled to readjust to the civilian world for years after the war's end.

Van Devanter states in Home Before Morning that "when the soldiers of World War II came home, they were met by brass bands, [and] ticker-tape parades, and people . . thankful for their service." ${ }^{13}$ Her own nightmarish homecoming experience was far different from these iconic images. Vietnam veterans' perception that they were denied the warm reception accorded the soldiers of America's past wars pervades their narratives. Philip Caputo somberly states in A Rumor of War that he and other soldiers who fought in Vietnam did not "return to cheering crowds, parades, and the pealing of great cathedral bells." ${ }^{14}$ Another memoirist notes that his return to the U.S. after thirteen months in Vietnam in no way corresponded to the "brass bands, victory parades ... and starry-eyed girls clinging to his neck" that he had once envisioned. ${ }^{15}$ Army veteran Frederick Downs asserts in his memoir that he fully expected to be met with "a band and welcoming committee" when his plane landed in the U.S., "just like movies and books had always portrayed," but this was not what happened. ${ }^{16}$

\footnotetext{
${ }^{13}$ Van Devanter, Home Before Morning, 209.

${ }^{14}$ Philip Caputo, A Rumor of War, New York: Holt, Rinehart and Winston, 1977; Owl Books, 1996), 337.

${ }^{15}$ W.D. Ehrhart, Passing Time: Memoir of a Vietnam Veteran Against the War (Amherst, MA: University of Massachusetts Press, 1995), 7. Originally published as Marking Time, New York: Avon Books, 1986.

${ }^{16}$ Frederick Downs, Aftermath: A Soldier's Return to America from Vietnam (New York: Norton, 1984), 95.
} 
The theme that veterans were ignored and unappreciated is also present in other types of homecoming stories. One author, for instance, writes of the complete indifference expressed by a shoe-store clerk when her father proudly told the man that she had recently returned home from Vietnam. ${ }^{17}$ Even when civilians expressed interest in learning about returning soldiers' war experiences, however, their comments and questions inevitably sounded stupid or insensitive to the ears of veterans. Several memoirs contain scenes in which civilians, some of them veterans of earlier conflicts, express foolish opinions about Vietnam-related matters that, in veterans' minds, could only be understood by someone who had been there. ${ }^{18}$ One veteran recalled that at his homecoming party an apparently well-meaning family friend asked him, offhandedly, "Well, did you kill anybody?"19

Van Devanter, of course, says that she was not just denied a parade when she came home, but was also openly abused and ridiculed by soldier-hating civilians. Similar claims are made in other veterans' narratives. One memoirist says that his plane was met by "war protestors" who "threw tomatoes and waved Baby Killer signs," 20 and another

\footnotetext{
${ }^{17}$ Winnie Smith, American Daughter Gone to War: On the Frontlines with an Army Nurse in Vietnam (New York: William and Morrow, 1992; Pocket Books, 1994), 253.

${ }^{18}$ Ron Kovic, Born on the Fourth of July (New York: McGraw Hill, 1976; reprint, New York: Akashic, 2005, 105, 110, 113; W.D. Ehrhart, Vietnam-Perkasie: A Combat Marine Memoir (Jefferson, NC: McFarland, 1983; reprint, Amherst, MA: University of Massachusetts Press, 1995), 273, 278-279; Rod Kane, Veteran's Day: A Combat Odyssey (New York: Orion; Pocket Book, 1990), 60.

${ }^{19}$ Al Santoli, Everything We Had: An Oral History of the Vietnam War by Thirty-Three American Soldiers Who Fought It (New York: Random House, 1981; Ballantine, 1983), 133. Several other veterans' narratives also contain references to civilians insensitively asking veterans if they had killed anyone in Vietnam, including Baker, Nam, 259; Bruce Weigl, The Circle of Hahn: A Memoir (New York: Grove Press, 2000), 154; Kane, Veteran's Day, 75.

${ }^{20}$ Johnnie M. Clark, Guns Up! (New York: Ballantine Books, 1984; 2002), 320-321.
} 
writes of being called a "murderer" by a girl working at an airport gift shop. ${ }^{21}$ Still another veteran claims that when he tried to walk down a Berkeley, California street in his uniform he was yelled at and spat on, and when he ducked into a bar to escape this torrent of abuse, people inside threw peanuts at him. ${ }^{22}$

Such episodes are reminiscent of veterans' homecoming accounts published in Bob Greene's 1989 book, Homecoming: When the Soldiers Returned Home from Vietnam. In the mid-1980's, Greene, a syndicated newspaper columnist, posed this question to the veterans among his readers: "Were you spit on when you returned from Vietnam?" Greene received "well over a thousand" responses to his query, and 132 of these letters were eventually published verbatim in Homecoming, about half of them written by veterans who claimed they were spat on when they returned to the U.S. ${ }^{23}$ The letters written by those who said they were spat on are downright shocking. On page after page, letter writers tell of landing in U.S. airports and being assaulted by anti-war "hippies" who threw eggs, spit in their faces or on their uniforms, and called them "baby killers" or "Army pigs." 24 While anti-war protestors are blamed for most of these incidents, ordinary citizens, including "a middle-aged lady"25 and three "nicely dressed" teenagers, ${ }^{26}$ are identified as attackers in other accounts. One letter writer asserts that

\footnotetext{
${ }^{21}$ Robert Mason, Chickenhawk (New York: Viking, 1983; Penguin, 2005), 463.

${ }^{22}$ Baker, Nam, 247-248.

${ }^{23}$ Bob Greene, Homecoming: When the Soldiers Returned from Vietnam (New York: Putnam,
} 1989), 8-16.

${ }^{24}$ For letters detailing stories of Vietnam veteran harassment that including spitting see Greene, Homecoming, 17-85. For letters detailing stories of veteran abuse that did not include spitting see Ibid., 75-250.

25 Ibid., 24. 
"verbal and physical abuse of returning Vietnam veterans" was not just meted out by "hippies," but by people "in all levels of American society."27

Due in part to Greene's book, stories about reviled and spat-upon soldiers became an integral part of America's collective memory of the Vietnam War. Several scholars have nevertheless posited convincing arguments that question the validity of such accounts. A 1995 study published in Social Problems analyzed 380 articles about antiwar demonstrations published in the New York Times, the Los Angeles Times and several other newspapers during the Vietnam era. The sociologists who conducted this study could find no reports in any of the publications "of behavior as crude as spitting on ... or directly taunting" returning soldiers. ${ }^{28}$ Only 6 percent of reported anti-war protests “could, using a liberal interpretation, classify as anti-troop activity initiated by activists themselves." 29 And in most cases, such protest activities involved National Guardsmen, military police, and other "uniformed personnel in a domestic policing role," not regular soldiers. ${ }^{30}$ Moreover, 15 percent of the newspaper articles surveyed were "clear and explicit ... accounts of movement activists speaking or acting favorably toward ordinary enlisted men."31

Jerry Lembke, a sociologist and Vietnam veteran, provides additional arguments against the legitimacy of the spat-upon-soldier stories in his 1998 book, The Spitting

\section{${ }^{26}$ Ibid., 23.}

27 Ibid., 24.

${ }^{28}$ Thomas D. Beamish, Harvey Molotch, and Richard Flacks, "Who Supports the Troops? Vietnam, The Gulf War, and the Making of Collective Memory," Social Problems 42, no. 3 (August 1995): 350.

${ }^{29}$ Ibid., 351.

30 Ibid.

${ }^{31}$ Ibid., 353. 
Image: Myth, Memory, and the Legacy of Vietnam. Lembke contends that not only are there no Vietnam-era newspaper accounts of protestors harassing returning troops, there is no contemporary documentation for such stories whatsoever--no photographs, court transcripts, police records, or FBI files. ${ }^{32}$ Protestors, Lembke points out, "undoubtedly would have been arrested" if they were regularly accosting soldiers at the nation's airports. ${ }^{33}$ A newspaper photographer or "some enterprising GI" with a camera, he adds, likely would have taken a picture of such an incident at some point. ${ }^{34}$

Because GIs returned from Vietnam to a country deeply divided by the war, it is possible that there were isolated incidents in which veterans were insulted, maybe even spat on, because of their participation in the war. It is unlikely that such episodes took place, however, because the anti-war movement was supportive of and worked with veterans and active-duty military personnel throughout the war. ${ }^{35}$ A prevailing theme at peace protests was that American soldiers should be brought home before any more were killed or wounded in a senseless conflict. In late 1969, for example, 40,000 civilians gathered in Washington, D.C. to participate in the "March Against Death," an event that highlighted the toll the war had taken on U.S. servicemen. Every participant in the twoday march carried a candle and a placard inscribed with the name of an American soldier killed in Vietnam. ${ }^{36}$ GIs had participated in the anti-war movement from the beginning,

\footnotetext{
32 Jerry Lembke, The Spitting Image: Myth, Memory, and the Legacy of Vietnam (New York: New York University Press, 1998), 72-73.

33 Ibid., 73.

${ }^{34}$ Ibid., 72-73.

35 Ibid., The Spitting Image, 6, 37-48, 67-68.

${ }^{36}$ Terry H. Anderson, The Movement and the Sixties (New York: Oxford University Press, 1995), 332.
} 
but after the 1968 Tet Offensive, anti-war activism among American troops, including those stationed in South Vietnam, was rampant. Thousands of soldiers participated in peace demonstrations, signed petitions against the war, and met to discuss their opposition to the conflict in "GI coffeehouses" operated by civilian activists. ${ }^{37}$ Anti-war organizations in the U.S. lauded the actions of such soldiers and declared 1968 "the 'Summer of Support' for the GI antiwar movement.,"38

Many memoirs feature attacks on veterans that are perpetrated by ordinary citizens, not activists or "hippies." Outside sources, however, do not support the suggestion made by these stories that most Americans openly despised Vietnam veterans during and immediately after the war. Harris polls taken in 1971 found that 80 percent of Americans "strongly agreed" that Vietnam veterans deserved respect, and only 3 percent of veterans described their reception from people their own age who did not serve as "not at all friendly." The results were essentially the same when veterans and nonveterans were asked these same questions eight years later. ${ }^{39}$ A 1980 U.S. Senate study based on these polls, Myths and Realities: A Study of Attitudes toward Vietnam Era Veterans,

${ }^{37}$ Ibid., 229-230, 319-321, 332, 417; H. Bruce Franklin, Vietnam and Other American Fantasies (Amherst, MA: University of Massachusetts, 2000), 62-70, 106-109. Another indication of civilian anti-war activists' support for Gls is the popularity of the Rolling Stones song, "Salt of the Earth," among Vietnamera student radicals. The song's lyrics include the lines "Say a prayer for the common foot soldier / Spare a thought for his back breaking work / Say a prayer for his wife and his children / Who burn the fires and who still till the earth."

${ }^{38}$ Franklin, Vietnam and Other Fantasies, 106-107. For more information on Vietnam-era GI activism see David Cortright, Soldiers in Revolt: The American Military Today (New York: Anchor Press, 1975).

${ }^{39}$ Myths and Realities: A Study of Attitudes Toward Vietnam Era Veterans (Washington: United States Government Printing Office, 1980), 39, 87. 
concluded that even though the American public thought the war was a mistake, it did "not hold the warrior responsible for the war."

There are other less quantifiable reasons why stories of spat-upon soldiers do not seem credible. Greene was convinced that such stories were true, but he admits that certain aspects of them do not "make sense." He questions whether anti-war "hippies" would have had "the nerve" to spit on soldiers "fresh from facing enemy troops in the jungles of Vietnam," or if soldiers, as many Homecoming accounts suggest, would have done nothing in response to being spat upon. ${ }^{41}$ Additionally, most of these anecdotes, notes Christian G. Appy, follow the same basic formula: "A returning veteran ... walks through the [airport] terminal, a hippie, often a girl, approaches, calls him a baby-killer, and spits at him." 42 Even harassed-veteran stories that do not closely follow this narrative almost always contain one or more of its essential elements, such as someone using the epithet "baby-killer." The "sameness" of these accounts, Appy argues, calls into question their "literal truthfulness.",43

${ }^{40}$ Ibid., xxxviii.

${ }^{41}$ Greene, Homecoming, 10; H. Bruce Franklin echoes these questions by doubting that "men just back from combat" would have "meekly walked away without attacking or even reporting" people who spat on them. Franklin, Vietnam and Other Fantasies, 62.

${ }^{42}$ Christian G. Appy, Working-Class War: American Combat Soldiers and Vietnam (Chapel Hill, NC: The University of North Carolina Press, 1993), 304.

43 Ibid., 304; There is one case in which two different memoirists' homecoming stories are strikingly and suspiciously similar to each other. In the epilogue of the 2002 edition of Johnnie M. Clark's popular memoir, Guns Up!, Clark says that he was arrested after "decking" one of the "war protestors" that met the plane that brought him home from Vietnam in 1969. Clark adds that he was quickly released from custody, however, because the policemen who arrested him were "old Marines" who sympathized with his plight. (Clark, Guns Up!, 320-321). A more obscure memoir, James T. Gillam's War in the Central Highlands of Vietnam, 1968-1970: A Historian's Experience, published in 2006, ends with essentially the same story. Gillam also says that he punched an anti-war civilian shortly after his disembarking from his plane ride from Vietnam, and that he too was quickly released because "one of the cops was a veteran." James T. Gillam, War in the Central Highlands of Vietnam, 1968-1970: A Historian's Experience (Lewiston, NY: The Edwin Mellen Press, 2006), 317. 
It is probable that veterans' accounts of being spat upon are exaggerated and inaccurate. It is unlikely, however, that memoirists were consciously lying when they reported dubious-sounding homecoming experiences. The appearance of these accounts is instead probably due to the inherent malleability of memory. The letters published in Homecoming were written in the late 1980's, and no memoirs or oral histories that feature harassed-veteran stories were published before $1981 .^{44}$ The years separating memoirists' homecoming experiences and when they recorded these episodes are crucial. As time passes, memories inevitably become distorted by external influences, and after the war ended Vietnam veterans were bombarded with the notion that they were figuratively and literally spat upon when they came home.

No Victory Parades: The Return of the Vietnam Veteran, a book based on interviews with 200 veterans, came out in 1971, while the war was still in progress. The author, Murray Polner, states in the introduction that the former soldiers he talked to were "unlike the returning servicemen of earlier wars, they have not been celebrated in film or song; there are no more victory parades." ${ }^{45}$ Around the same time that Polner's book was published, the news media and mental health professionals were starting to disseminate the claim that large numbers of Vietnam veterans were suffering from readjustment problems partly because they were not given proper homecomings. In 1973, the image of the "forgotten" veteran was contrasted in the media to the attention and praise heaped

\footnotetext{
${ }^{44}$ The first published accounts of returning soldiers being spat upon and abused by American civilians appeared in the oral history compilation, Nam: The Vietnam War in the Words of the Soldiers Who Fought There. Baker, Nam, 241-268.

${ }^{45}$ Murray Polner, No Victory Parades: The Return of the Vietnam Veteran (New York: Holt, Rinehart and Winston, 1971), xiv. A Vietnam veteran quoted on page ten in No Victory Parades explains that older veterans cannot relate to soldiers returning from Southeast Asia because "when [earlier veterans] came home, bands played and there were parades."
} 
upon the American POWs who were released as part of the agreement that ended the war. $^{46}$ In the 1980's, thousands of Americans tried to make up for the supposedly poor treatment of Vietnam veterans in years past by cheering them on as they marched in "welcome home" parades. ${ }^{47}$

The origin of the idea that returning soldiers were spat upon is unclear, but a similar event is portrayed in Coming Home (1978). At the beginning of the film, one of the main characters, a Vietnam veteran, is accosted by chanting anti-war demonstrators soon after disembarking from the plane that has brought him home from Southeast Asia. The first major manifestation of the claim that protestors literally spat on soldiers appeared in the 1982 film, First Blood. Starring Sylvester Stallone as John Rambo, First Blood is about a disturbed Vietnam veteran who goes on a rampage in a small American town after being harassed by the local sheriff. ${ }^{48}$ Near the conclusion of the movie, Rambo, who is cornered by police and experiencing an emotional breakdown, identifies the source of his troubles:

And I did what I had to do to win. But somebody wouldn't let us win. Then I come back to the world and I see all those maggots at the airport. Protesting me. Spitting. Calling me baby killer, and all kinds of vile crap. Who are they to protest me? Huh? ${ }^{49}$

Subsequent Vietnam War films perpetuated the concept of the abused veteran. In 1987's Hamburger Hill, a character who served in Vietnam says that "hippies" threw

${ }^{46}$ Eric T. Dean, Jr., Shook Over Hell: Post-Traumatic Stress, Vietnam, and the Civil War (Cambridge, MA: Harvard University Press, 1997), 7-8, 12, 19; Lembke, The Spitting Image, 102-105.

47 In 1987, "25,000 Vietnam veterans marched in a New York City ticker-tape parade attended by one million people," and similarly large-scale events of this type were held in Chicago and Houston around the same time. Smaller "welcome home" parades were held in towns and cities across the nation, from Modesto, California to Northfield, Vermont. Dean, Shook over Hell, 19-20.

\footnotetext{
${ }^{48}$ Lembke, The Spitting Image, 144-146, 176-177.

${ }^{49}$ Ibid., 176-177.
} 
bags of "dog shit" at him at the airport. ${ }^{50}$ In Rambo: First Blood Part II (1985), Rambo tells another character that when he returned to the U.S. from Vietnam he "found another war going on ... A war against the soldiers returning." "51 By the end of the 1980's, the concept of the spat-upon veteran was so ingrained in the minds of Americans that it affected how they viewed the Persian Gulf War of 1991, America's first major military conflict since its withdrawal from Vietnam in 1973. In the lead up to the war, Bush administration officials and proponents of its military policies urged Americans to support the thousands of U.S. troops poised on the border of Saddam Hussein's Iraq. According to this point of view, supporting the soldiers in the Gulf meant doing the opposite of what most Americans had supposedly done a generation earlier: undercut and abuse the soldiers who fought in Vietnam. During this pre-war period, the news media reported that GIs in Saudi Arabia were worried about being spit on when they came home, and U.S. anti-war groups struggled to distance themselves from the cruel acts supposedly committed by their Vietnam-era predecessors. ${ }^{52}$

Stories of spat-upon veterans were part of a larger shift in the collective memory of the war that occurred in the years following the end of the war. There was widespread "antimilitarist" sentiment in the United States in the immediate postwar period, and many Americans at the time saw the Vietnam conflict as a lesson against military interventionism. One manifestation of this shift in societal attitudes was the removal of war from childhood pursuits: the war games, films, and toys that many post-World War II boys had grown up with were discredited in post-Vietnam America. The presidency of

\footnotetext{
${ }^{50}$ Hamburger Hill, directed by John Irvin (1987).

${ }^{51}$ Lembke, The Spitting Image, 177.

52 Ibid., 11-26. Beamish, Molotch, and Flacks, "Who Supports the Troops?," 344-346.
} 
Ronald Reagan indicated, however, that the war in Vietnam had not fully extinguished what Tom Engelhardt calls American “victory culture." In the 1980's, Reagan was the chief advocate for the rehabilitation of the Vietnam conflict into a "noble cause" that was thwarted by anti-war protestors and weak-willed American politicians. According to this new conception of the war, Vietnam veterans were the chief victims of these actions because, as Rambo laments, their leaders and fellow citizens would not let them win. This "revisionist" version of the war suffused American culture in the 1980's and went nearly unchallenged in the years to come. ${ }^{53}$

To veterans who came home with psychological problems, hostile or indifferent civilians were the least of their worries. In the latter years of the war, the news media and mental health professionals were already reporting that some soldiers who served in Southeast Asia were suffering from psychological issues linked to their wartime service. Early on, before they were completely understood, these problems were grouped under the unofficial heading of "Post-Vietnam Syndrome," or "PVS." But eventually, most Vietnam veterans afflicted by war-related psychological maladies were diagnosed with "post-traumatic stress disorder," or "PTSD," a condition first officially recognized by the American Psychiatric Association (APA) in $1980 . .^{54}$

According to the APA's Diagnostic and Statistical Manual of Mental Disorders, PTSD is not restricted to Vietnam veterans, or even to war veterans in general, but can

${ }^{53}$ Lynda Boose, "Techno-Muscularity and the "Boy Eternal”: From the Quagmire to the Gulf," in Cultures of United States Imperialism, eds. Amy Kaplan and Donald E. Pease (Durham, NC: Duke University Press, 1993), 583-601; Tom Engelhardt, The End of Victory Culture: Cold War America and the Disillusioning of a Generation (New York: BasicBooks, 1995), 4-15; Susan Jeffords, The Remasculinization of America: Gender and the Vietnam War (Bloomington, IN: Indiana University Press, 1989), xi-xv, 116143,168-169; Richard Slotkin, Gunfigher Nation: The Myth of the Frontier in Twentieth-Century America (New York: Atheneum, 1992), 624-654.

${ }^{54}$ Dean, Shook Over Hell, 14-22, 40-44; Lembke, The Spitting Image, 101-115. 
potentially strike anyone who has "been exposed to one or more traumatic events---

events that are psychologically distressing and outside the range of usual human

experience."55 People who experience such events, and subsequently suffer from PTSD,

exhibit "three classes of symptoms":

re-experiencing of the traumatic event, avoidance of stimuli associated with the event or numbing of general responsiveness, and increased arousal. Examples of re-experiencing phenomena include recurrent, intrusive, and distressing memories or dreams of the event(s). Avoidance and numbing symptoms include deliberate efforts to avoid or escape thoughts or feelings associated with the event(s) and feelings of detachment or estrangement from others that develop after the trauma. Symptoms of increased arousal include difficulty falling or staying asleep, hypervigilance, exaggerated startle response, and physiologic reactivity in the face of events that symbolize or resemble an aspect of the traumatic event. ${ }^{56}$

In 1983, after years of speculation about the mental health of Vietnam veterans, the U.S. Congress launched an investigation into the issue dubbed the "National Vietnam Veterans Readjustment Study (NVVRS).” Completed in 1988, the NVVRS found that 30.6 percent of male Vietnam veterans, and 26.9 percent of female Vietnam veterans, "had full-blown [PTSD] at some time during their lives," while 15.2 percent of male veterans, and 8.5 percent of their female counterparts currently suffered from PTSD. ${ }^{57}$ In addition, 11.1 of men, and 7.8 percent of women studied currently had "partial PTSD." The NVVRS also concluded that "the prevalence of PTSD and other postwar psychological problems is significantly, and often dramatically, higher among those with high levels of exposure to combat."

${ }^{55}$ Richard A. Kulka and others, Trauma and the Vietnam War Generation: Report of Findings from the National Vietnam Veterans Readjustment Study (New York: Brunner/Mazel, 1990), 31.

${ }^{56}$ Ibid., 31-32.

${ }^{57}$ Ibid., xxvii. 
to how it applies to this dissertation, because the great majority of memoirists saw heavy combat in Vietnam.

Due to the increasing amount of attention paid to the psychological problems of Vietnam veterans in the years after the war, more men and women who came home from Southeast Asia with PTSD and other mental issues were able to get the help they needed. The downside of this heightened attention was the proliferation of the stereotype of the crazed Vietnam veteran. Beginning in the early 1970's, stories of veterans who had been turned into misfits, criminals, or killers by their experiences in Vietnam became a favorite topic of the news media, and the troubled or psychotic Vietnam veteran became a common character in popular culture. ${ }^{59}$ In a 1979 Esquire article titled, "The Violent Vet," award-winning writer and Vietnam veteran Tim O'Brien asserted that television shows and movies of the period offered two distinct, yet equally offensive, versions of the psychologically wounded Vietnam veteran character. Whereas television programs, he argued, generally portrayed veterans as mentally deranged killers, Hollywood, “aiming for psychological understanding and insight," produced veteran characters who were "baleful, explosive, spiritually exhausted, tormented, with brains like whipped cream." 60

O'Brien was indignant about popular culture's portrayal of Vietnam veterans as mentally unbalanced, and his arguments and criticisms have been echoed by other veterans. $^{61}$ It is all the more interesting, then, that a great number of memoirists readily

\footnotetext{
${ }^{58} \mathrm{Ibid}$.

${ }^{59}$ Lembke, The Spitting Image, 107, 110; Dean, Shook Over Hell, 14, 20-22.

${ }^{60}$ Tim O’Brien, “The Violent Vet," Esquire, December 1979, 96.
} 
admit that they suffered from psychological problems as a result of wartime service. Very few veterans explicitly say that they suffered from PTSD after they came home, but the psychological problems they list in their narratives very often fall into one of the three classes of PTSD symptoms. Examples of memoirists who constantly "re-experienced" distressful memories of the war include a veteran who writes of not being able to stop thinking of the horrible things he saw in Vietnam, even when he tried to drown out such thoughts by listening to music. ${ }^{62}$ Others were haunted by reoccurring war-related dreams, such as the memoirist who dreamed of Army helicopters landing in his suburban neighborhood to take him back to Vietnam, ${ }^{63}$ and another whose sleep was plagued by images of comrades who died in battle. ${ }^{64}$

A number of veterans report that they felt alienated from family and friends when they came home, avoided social interaction, and felt as if their feelings were numbed. One former nurse became a virtual recluse when she came home, rarely leaving her bedroom and avoiding contact with her concerned parents and friends. ${ }^{65}$ Bob Kerrey, the onetime governor of Nebraska and presidential candidate, was evacuated to the U.S. after he was severely wounded in Vietnam, but requested to be sent to a hospital that was as far away from his family as possible. ${ }^{66}$ Some veterans say such problems caused great

\footnotetext{
${ }^{61}$ For example, see James Webb, "Viet Vets Didn't Kill Babies and They Aren't Suicidal," The Washington Post, 6 April 1986, C1.

62 John Ketwig, And a Hard Rain Fell: A G.I.'s True Story of the War in Vietnam (New York: Macmillian, 1985), 212-213.

${ }^{63}$ Nathaniel Tripp, Father, Soldier, Son: Memoir of a Platoon Leader in Vietnam (South Royalton, Vermont: Steerforth Press, 1996), 1-4.

64 James R. McDonough, Platoon Leader (Novato, CA: Presidio, 1985), 4-5.

${ }^{65}$ Smith, American Daughter Gone to War, 248-250.
} 
strains on romantic relationships, such as the memoirist who labeled himself a "combat bachelor" because his emotional issues continually wrecked his postwar relationships with women. ${ }^{67}$

Perhaps the most common psychological problems reported in narratives are those that fall into the third PTSD category, "increased arousal." Many veterans say that when they returned to the United States they had trouble sleeping, were startled by fireworks and other loud noises, and generally could not "turn off" the constant state of vigilance and being ready for action that developed over months of combat duty in Vietnam. One veteran-author recalled that in the months following his return to the U.S., he prepared for potential attackers when inside buildings by choosing a seat facing the door, his back to the wall. ${ }^{68}$ Another memoirist says that he still reflexively looks for ambushes and booby-traps more than a decade after coming home from Southeast Asia. ${ }^{69}$

Many people with PTSD try to deal with their problems by excessive drinking or self-medicating with drugs, ${ }^{70}$ and several memoirists who came home with PTSD-like symptoms also developed substance abuse problems. Winnie Smith, the nurse who rarely left her room for months after she returned home, spent most of those lonely, solitary weeks drowning her sadness in alcohol. ${ }^{71}$ Bruce Weigl, the veteran who always sat with his back to the wall, states on the first page of his memoir that during the period of "black

${ }^{66}$ Bob Kerrey, When I Was a Young Man: A Memoir (New York: Harcourt, 2002), 196, 214.

${ }^{67}$ Kane, Veteran's Day, 328.

${ }^{68}$ Weigl, The Cirlce of Hanh, 133.

${ }^{69}$ David Donovan, Once a Warrior King: Memories of an Officer in Vietnam (New York: McGrawHill, 1985), 306.

\footnotetext{
${ }^{70}$ Kulka, Trauma and the Vietnam War Generation, 283.

${ }^{71}$ Smith, American Daughter Gone to War, 244-292.
} 
postwar grief" that followed his return home, he "lost whole years" of his life to drug addiction. $^{72}$ Memoirist Rod Kane, the self-described "combat bachelor," admits in his book that he got drunk every night for a year after returning to the United States. ${ }^{73}$ Two other veterans, Robert Mason and Lewis Puller, Jr., both devote large portions of their memoirs to chronicling the horrible postwar years they spent trying to assuage their psychological problems with alcohol. ${ }^{74}$

In the latter years of the war, the first mental health professionals who focused on the psychological problems of American soldiers returning from Vietnam brought afflicted veterans together to talk about their problems in "rap groups."75 After the war ended, this form of group therapy was touted as the preferred method of treatment for Vietnam veterans with war-related mental illnesses. ${ }^{76}$ By 1981, almost 200 "store-front vet centers" featuring group therapy existed around the country. ${ }^{77}$ Several veterans mention that they turned to this kind of treatment when their readjustment problems became unbearable. Former marine Albert French, for instance, writes at length in his memoir, Patches of Fire: A Story of War and Redemption, of his experiences as a rap

${ }^{72}$ Weigl, The Circle of Hanh, 1.

${ }^{73}$ Kane, Veteran's Day, 76.

${ }^{74}$ Mason, Chickenhawk, 469-474; Robert Mason, Chickenhawk Back in the World: Life After Vietnam (New York: Viking, 1993), 14-17, 20-27, 386-387; Lewis B. Puller, Jr., Fortunate Son (New York: Grove Weindenfeld, 1991), 331-360.

${ }^{75}$ Lembke, The Spitting Image, 105-106.

${ }^{76}$ For a list of articles and books that chronicle the genesis of Vietnam veteran rap groups, or advocate their use, see Michael E. Reeves, M.D. and Michael J. Maxwell, M.S., "The Evolution of a Therapy Group for Vietnam Veterans on a General Psychiatry Unit," Journal of Contemporary Psychotherapy 17, no. 1 (Spring 1987), 23-24.

${ }^{77}$ Dean, Shook Over Hell, 15. In 1979, the U.S. government officially appropriated funds for "vet centers" with the creation of the "Vietnam Veterans' Outreach Program." Lembke, The Spitting Image, 109. 
group participant. Almost twenty years after his tour in Vietnam, French became plagued by incessant thoughts about comrades who had died in battle. In desperation he turned to his local "Vietnam Veterans Center" for help. Once a week, French and a group of fellow combat veterans met at the center and shared their troubles, from the anger they felt at spouses for not being able to understand their problems, to the nightmares that kept them awake at night.

The primary reason cited by veterans in their narratives for why rap group sessions were helpful was that they involved other veterans, the only people who could possibly relate to what they were going through. The members of French's group called themselves "brothers" because of their shared status as veterans, and French says that he only felt comfortable with the therapist who led the meetings because he too had served in Vietnam. ${ }^{78}$ A veteran who felt alienated from non-veterans organized a group of veterans who met to talk about the war and readjustment issues in an atmosphere reminiscent of "the comradeship that [they] had in service."79 Another former soldier says that no one in his life outside his veterans' group, including his wife, could understand the nightmares and "flashbacks" that disrupted his post-Vietnam existence. ${ }^{80}$ Memoirists who did not participate in formal group therapy sessions also say that their postwar troubles were eased by spending time with fellow veterans. Ron Kovic, for instance, suggests in his famous memoir, Born on the Fourth of July, that the first time he felt any relief from the crushing guilt and depression that characterized his return from

${ }^{78}$ Albert French, Patches of Fire: A Story of War and Redemption (New York: Anchor Books, 1997), 158-174.

${ }^{79}$ Wallace Terry, Bloods: An Oral History of the Vietnam War by Black Veterans (New York: Random House, 1984; Ballantine, 1985), 256.

${ }^{80}$ Santoli, Everything We Had, 158. 
Vietnam was when he became an active member of Vietnam Veterans Against the War $(\mathrm{VVAW}){ }^{81}$

Besides talking and associating with others who had served in Vietnam, memoirists used other means to heal psychological wounds and overcome readjustment problems. Several veterans suggest that they appreciated and benefited from the public events staged around the country in the 1980's that were aimed at giving Vietnam veterans the recognition they were supposedly denied when they came home years earlier. Two veterans end their memoirs with accounts of joyfully marching in Reaganera "welcome home parades," 82 and two others did not march, but happily watched such events from the sidelines. ${ }^{83}$ Another memoirist says that he finally "came home" from the war when he visited the Vietnam Veterans Memorial. ${ }^{84}$ Along with his participation in the veterans' group, French cites a trip to a replica of the memorial that was set up near his home as a turning point in his recovery from his psychological problems. Visiting the memorial gave him "a real good feeling" because it afforded him his first chance to "say goodbye" to friends who had died in Vietnam. ${ }^{85}$

The theme of eventual recovery from postwar readjustment problems, psychological or otherwise, is also manifested in the great academic and professional success achieved by memoirists. Of the fifty-one veterans whose memoirs serve as the basis of this dissertation, thirty pursued higher education after they came home, seven of

\footnotetext{
${ }^{81}$ Kovic, Born on the Fourth of July, 147-148.

${ }^{82}$ Kane, Veteran's Day, 343-345; Donovan, Once a Warrior King, 312.

${ }^{83}$ Mason, Chickenhawk Back in the World, 366-367; Ketwig, And a Hard Rain Fell, 301.

${ }^{84}$ Matthew Brennan, Brennan's War: Vietnam 1965-69 (Novato, CA: Presidio Press, 1985), 275.

${ }^{85}$ French, Patches of Fire, 177.
} 
these garnering bachelor's degrees, and nineteen earning MBAs, PhDs, and other postgraduate degrees. A number of memoirists were famous and/or successful before their memoirs were published, with most acquiring this status as either authors or politicians. Kerrey, John McCain, and Colin Powell all wrote Vietnam memoirs, and all went on after the war to play prominent roles in national politics. Tim O'Brien, Larry Heinemann, Bruce Weigl, and several others produced critically acclaimed fictional works about the war before and after publishing their memoirs. Three others, French, Tobias Wolff, and Tracy Kidder, authored successful non-Vietnam novels before their memoirs were published. Several of the most celebrated Vietnam-veteran memoirs, such as Caputo's A Rumor of War and Kovic's Born on the Fourth of July, were themselves the source of their authors' fame. Furthermore, since titles included in the primary group of memoirs were chosen for their prominence, every one of their authors achieved the rare distinction of writing a published, notable book.

From the late 1960's onward, journalists, mental health professionals, filmmakers, and other commentators have been spreading the word that Vietnam veterans were unique in U.S. history because they, unlike the veterans of earlier wars, were not received as heroes by the American public. Vietnam veterans were not only scorned or ignored, so the story went, but they also suffered from postwar psychological problems that were unknown among the returning soldiers of earlier generations. Adding to the strength of these ideas is that they are repeated by Vietnam veterans themselves in memoirs, oral histories and other personal narratives.

Regardless of the prevalence of these concepts in news media, films, and the accounts of the veterans themselves, they are nevertheless basically false. In the 
aftermath of virtually every war fought by the United States in its history, its soldiers experienced postwar difficulties that would be familiar to any reader of Vietnam veterans' narratives. When the troops of the victorious Continental Army left the battlefield in 1783, they were met with "few, if any, official welcomes . . no homecoming parades, no flags flying nor bands playing, [and] no smiles from many of the civilians whose fortunes had waxed with their liberties." 86 Veterans flooded the cities of the newly-independent United States in search of work, but employment was scarce. When former soldiers became destitute, they could not, at least in the immediate postwar years, expect any help from the government they had fought to create. Exasperated Continental Army veterans were the leaders of "Shay's Rebellion," the 1786 armed uprising of poor farmers in western Massachusetts against a judicial system that had sent many of their number to debtors' prisons. $^{87}$

Decades later, when the bloody American Civil War finally ended, thousands of Union soldiers marched in victory parades in Washington D.C. and other cities, and newspapermen, politicians, and ordinary Americans heaped praise and gratitude upon the men who had defeated the Southern rebels. ${ }^{88}$ The glow of victory quickly faded, however, when many Northern veterans could not find work, became homeless, or were preyed upon by swindlers and thieves. Some former soldiers concealed their history of military service because veterans were seen by some potential employers as "unstable,

${ }^{86}$ Richard Severo and Lewis Milford, The Wages of War: When America's Soldiers Came Home from Valley Forge to Vietnam (New York: Simon and Schuster, 1989), 26.

${ }^{87}$ Ibid., 22-28, 59-63. On homelessness among veterans following wars during the colonial period and the American revolution, see also Kenneth L. Kusmer, Down and Out, On the Road: The Homeless in American History (New York: Oxford University Press, 2002), 14, 16.

${ }^{88}$ Dean, Shook Over Hell, 94-97. Many Civil War veterans who marched in such parades, however, later recalled that they had found such parades tedious and unnecessary. 
untutored, unmanageable---a bad risk." 89 Many veterans apparently turned to crime to make ends meet, because in the years following the end of the war, prison officials from Massachusetts to Wisconsin reported that their jails were filling up with Union veterans. Of course, the situation was even worse for Confederate veterans who returned home to destroyed cities and a wrecked economy, and worse still for African-American Union veterans whose service was rewarded with second-class citizenship and lynchings. ${ }^{90}$

A few decades later, the American "doughboys" who fought in World War I came home in 1918 and 1919 to "high unemployment and runaway inflation," and when the Great Depression descended on the U.S. in late 1929, things got much worse. In the spring of 1932, a group of destitute World War I veterans walked and "rode the rails" from Oregon to Washington, D.C. to demonstrate support for the passage of a bill in the U.S. Congress that would have provided immediate financial assistance to veterans in the form of "bonuses" that otherwise would not be distributed until 1945. These "bonus marchers" and their families set up camp in the nation's capital, where their ranks eventually grew to 20,000 to 40,000 veterans. In July 1932 , however, the marchers were chased out of Washington by U.S. Army troops under the command of Gen. Douglas MacArthur, on orders from President Herbert Hoover. ${ }^{91}$

Vietnam veterans most often compare their own negative homecoming experiences to those of the World War II veterans who supposedly "returned home to a

${ }^{89}$ Severo and Milford, The Wages of War, 137; Kusmer, Down and Out, On the Road, 36-38.

${ }^{90}$ Ibid., 139-140, 163-168.

91 Ibid., 241-279; Kusmer, Down and Out, On the Road, 202-03. The most thorough study of the Bonus Army is Paul Dickson and Thomas B. Allen, The Bonus Army: An American Epic (New York: Walker and Company, 2004). 
grateful nation happy, healthy, and respected."92 There is definitely some truth to this idea, for the soldiers who fought in World War II received more postwar support than veterans of any previous American war. Unlike earlier generations of veterans, the men who served in World War II did not have to form advocacy groups after the war and spend years petitioning the government for old-age pensions and other benefits. ${ }^{93}$ On June 22, 1944, more than a year before the war ended, President Franklin D. Roosevelt, who felt that veterans were "entitled to definite action to help take care of their special problems," signed the Servicemen's Readjustment Act into law. ${ }^{94}$ Better known as the “GI Bill,” this measure provided veterans with fifty-two weeks of unemployment compensation, low-interest home and business loans, and financial assistance for education and job training. ${ }^{95}$ The GI Bill was not perfect, but its programs nevertheless helped produce "a generation of well-educated professionals, businessmen, and homeowners who became the basis of a greatly strengthened American middle class."96

Though they were perhaps treated better than any other generation of veterans before or since, the homecoming experience for World War II veterans was not all tickertape parades and adoring crowds. In fact, most World War II troops came home alone from Europe or Asia, not in units, and few participated in victory parades. ${ }^{97}$ In the early postwar years, veterans faced labor unrest, rising inflation, and a severe housing

\footnotetext{
92 Thomas Childers, Soldier from the War Returning: The Greatest Generation's Troubled Homecoming from World War II (Boston: Houghton Mifflin Harcourt, 2009), 3-4.

${ }^{93}$ Dean, Shook Over Hell, 268.

${ }^{94}$ Severo and Milford, The Wages of War, 288.

95 Ibid., 287-290.

96 Ibid., 290.

97 Lembke, The Spitting Image, 119-120.
} 
shortage. ${ }^{98}$ Thousands of former fighting-men lived with family and friends if they were lucky, or in "barns, trailers, decommissioned streetcars ... even automobiles," if they were not. ${ }^{99}$ A majority of GIs surveyed in 1945 agreed with the statement, "On the whole, I think the Army has hurt me more than it helped me." ${ }^{100}$ A 1947 poll found that 48 percent of veterans thought the war had made their life worse, and that 41 percent believed that military service had made them "More nervous, high-strung, restless ... [and] tense." ${ }^{101}$ Despite the "public euphoria" occasioned by the war's end, many Americans at the time worried that years of combat had turned GIs into killers or criminals. ${ }^{102}$

The mutual hostility that developed between veterans and nonveterans following World War II is reminiscent of the theme of veteran-nonveteran conflict that is prevalent in Vietnam-veteran narratives. Conflict of this sort, however, goes back much further than World War II. In When Johnny Comes Home, a 1944 history of American war veterans, Dixon Wecter argued that tensions existed between veterans and civilians in the aftermath of every American military conflict beginning with the Revolutionary War. As he astutely put it, soldiers invariably return home from the battlefield believing that civilians are indebted to them for the hardships they endured on the nation's behalf. Veterans, however, see their sacrifices as so great that civilians can never really pay off

\footnotetext{
${ }_{98}$ Michael D. Gambone, The Greatest Generation Comes Home: The Veteran in American Society (College Station, TX: Texas A\&M University Press, 2005), 23-24.

${ }^{99}$ Childers, Soldier from the War Returning, 7.

${ }^{100}$ Stouffer, Samuel A. Stouffer and others, The American Soldier: Combat and its Aftermath, vol. 2 (Princeton, NJ: Princeton University Press, 1949), 610-612.

${ }^{101}$ Ibid., 610-612.

${ }^{102}$ Childers, Soldier from the War Returning, 6-8.
} 
that debt. ${ }^{103}$ During the latter years of the American Civil War, embittered Union soldiers thought Northern civilians were selfish and ungrateful. When they finally came home, many Union veterans, like many U.S. military personnel who served in Vietnam, could only relate to other veterans. ${ }^{104}$ Psychiatrist Jonathan Shay argues in his book, Odysseus in America: Combat Trauma and the Trial of Homecoming, that conflict between war veterans and civilians goes back at least to the days of Ancient Greece. ${ }^{105}$ Just as negative homecoming experiences and conflicts with civilians were not unique to Vietnam veterans, neither were war-related psychological problems. Whereas Vietnam veterans were diagnosed with "post-Vietnam syndrome" and "post-traumatic stress disorder," veterans of World Wars I and II with similar problems were labeled as victims of "shell shock" and "combat fatigue." Historian Eric T. Dean, Jr. persuasively argues in his book, Shook Over Hell: Post-Traumatic Stress, Vietnam, and the Civil War, that untold numbers of Civil War veterans were afflicted with the psychological disorder now known as PTSD. ${ }^{106}$ Shay shows in Odysseus in America and an earlier book, Achilles in Vietnam: Combat Trauma and the Undoing of Character, that Achilles, Odysseus, and other legendary warriors chronicled in the epic poetry of Ancient Greece also suffered combat-related psychological problems. ${ }^{107}$ Such studies make it clear that psychological trauma is not the byproduct of certain types of wars, but of all wars.

\footnotetext{
${ }^{103}$ Dixon Wecter, When Johnny Comes Marching Home (Cambridge, MA: Houghton Mifflin, 1944), 51-52.

${ }^{104}$ Gerald F. Linderman, Embattled Courage: The Experience of Combat in the American Civil War (New York: The Free Press, 1987), 216-240.

105 Jonathan Shay, Odysseus in America: Combat Trauma and the Trials of Homecoming (New York: Scribner, 2002), 12-18, 120-153.

${ }^{106}$ Dean, Shook Over Hell, 26-40, 91-179.
} 
Veterans cannot be blamed, however, for not including accurate historical details about the postwar experiences of earlier veterans in their narratives. For one thing, memoirs and are inherently self-focused; veterans produce narratives to talk about their wartime experiences, not those of previous generations. Additionally, most Vietnam veterans, like most Americans in general, probably knew nothing about the readjustment problems that plagued ex-soldiers throughout history. By the time the baby boomers were coming of age, the tensions and conflicts that occurred when the troops came home after World War II had long been forgotten. Many of the movies and television shows Vietnam veterans had watched when they were growing up were about World War II and other conflicts, but most of these productions portrayed war as a glorious adventure, saying nothing about the readjustment problems that fighting men encountered when they came home. In fact, as the celebration of the "greatest generation" in recent years demonstrates, the idealization of the World War II era in American culture continues unabated into the present. Many veterans had fathers, uncles, and neighbors who were real-life veterans of World War II or the Korean conflict, but such men were members of a generation that was encouraged to keep bad memories and inner conflicts bottled up inside and hidden from view. ${ }^{108}$

A good way to illustrate the falsity of the glorified version of World War II (and warfare in general) that was presented to future Vietnam veterans is to examine the life of World War II hero and postwar movie star, Audie Murphy. Murphy, a son of Texas sharecroppers who joined the U.S. Army at age seventeen with a falsified birth

${ }^{107}$ See Jonathan Shay, Achilles in Vietnam: Combat Trauma and the Undoing of Character (New York: Atheneum, 1994; Shay, Odysseus in America, 149-153.

${ }^{108}$ Childers, Soldier from the War Returning, 8. 
certificate, fought in Europe from 1943 to 1945, and came back to America with the Congressional Medal of Honor and thirty-two other awards, making him the most decorated American soldier of the war. After the war, Murphy became a popular Hollywood actor, starring in over forty movies between 1948 and 1969, most of them war movies and westerns. He even played himself in the World War II picture, To Hell and Back (1955), based on his 1949 autobiography of the same name.

Several memoirists say that Murphy was one of their role models growing up, but what they, or any of his other fans, did not know, was that their hero had come back from Europe with severe combat-related psychological problems. Murphy almost certainly suffered from what is now called PTSD. Soon after he returned home, Murphy's family noticed that there was something wrong with him: he was jittery, stressed-out, nervous, and tortured by nightmares. As time went on, and Murphy became a star, his personal life only got worse. His nightmares got so bad that he occasionally woke up and grabbed the handgun he always kept at his bedside and fired at imaginary enemies in the darkness of his bedroom. On movie sets, at restaurants, and at home with his wife, Murphy went into rages that often ended with him physically assaulting people or threatening them with firearms. In the years before he died in a 1971 plane crash, Murphy talked about committing suicide and was arrested several times for beating up strangers. ${ }^{109}$

Veterans' narratives are also misleading in that they generally feature the theme of eventual post-military recovery and success. At first glance, government-sponsored studies of Vietnam veterans seemingly support the validity of this theme. The authors of the NVVRS asserted that their findings showed that "the majority of Vietnam theater

${ }^{109}$ Don Graham, No Name on the Bullet: A Biography of Audie Murphy (New York: Viking, 1989), 23, 122-124, 145-150, 174, 189-190, 202, 216, 220-221, 226, 257, 271-325. 
veterans have made a successful reentry into civilian life and are currently experiencing few symptoms of PTSD or other readjustment problems."110 Another study, Legacies of Vietnam: Comparative Adjustment of Veterans and Their Peers, published in 1981, determined that veterans had achieved some significant educational and workforce successes after they came home. Using surveys taken in the late 1970's, Legacies found that 70 percent of Vietnam veterans "resumed their educational careers following" military service, ${ }^{111}$ and that most "did so within the first year following release."112 According to the study, as of 1977, there "were no substantial differences between veterans and non-veterans in unemployment rates," and "veterans had higher median wages than non-veterans."113 The study also determined that black veterans were better educated and had better jobs than African Americans who did not serve. ${ }^{114}$

Closer scrutiny of these studies, however, shows that the mental and physical health, education, and employment situations for Vietnam veterans were not entirely positive. Although the NVVRS concluded that the majority of veterans were not suffering from PTSD by 1988 , the 26.3 percent of veterans who currently had either "full-blown" or "partial" PTSD represented a significant minority. ${ }^{115}$ Furthermore,

${ }^{110}$ Kulka, Trauma and the Vietnam War Generation, xxvii.

${ }^{111}$ Legacies of Vietnam: Comparative Adjustment of Veterans and their Peers (Washington: United States Government Printing Office, 1981), 7. From 1970 to 1972, the Vietnam veteran unemployment rate was significantly higher than the national unemployment rate, but "by 1973 returning vets had been reabsorbed into the economy." Dean, Shook Over Hell, 10-11.

112 Legacies of Vietnam, 8. The study also found that "two-thirds of all veterans worked full time" while "enrolled in educational training . . . in spite of the fact that the majority of veterans were full-time students."

$$
\begin{aligned}
& 113 \text { Ibid., } 7 . \\
& 114 \text { Ibid., 7-9. }
\end{aligned}
$$


research has shown that, for many people, PTSD is irreversible, so it is likely that many of the veterans who had problems in the late-1980's continued to have problems afterward. Unfortunately, the fact is that many veterans with PTSD, contrary to suggestions made in veterans' narratives, never recovered from the psychological injuries they incurred in Vietnam. ${ }^{116}$

Not all combat-related injuries, of course, were psychological. Thousands of American soldiers came home from Vietnam with battle wounds. Puller and several other memoirists were terribly injured during their tours. But these authors overcame their disabilities and achieved professional success. Scores of other wounded veterans were surely not so fortunate. Thousands of soldiers returned to America with physical ailments caused by exposure to “Agent Orange." Beginning in 1961, the U.S military, seeking to "remove the foliage cover which had afforded concealment to the enemy," sprayed eighteen million gallons of chemical defoliant over South Vietnam. ${ }^{117}$ Approximately 60 percent of the defoliant sprayed was "Agent Orange,"118 a chemical which "contained TCDD-dioxin, the most toxic known substance." ${ }^{119}$ Many veterans who had been exposed to Agent Orange suffered "from skin rashes, weakness of limbs, nervous disorders, liver disease, ... [and] cancer." ${ }^{120}$ No memoirists indicate that they

${ }^{115}$ Kulka, Trauma and the Vietnam War Generation, xxvii.

${ }^{116}$ Shay, Odysseus in America, 149-150.

${ }^{117}$ Paul Feeny and Jim Allaway, "The Ecological Impact of the Air War," in Vietnam and America: A Documented History, eds. Marvin E. Gettleman and others (New York: Grove Press, 1985), 464.

118 Ibid., 466.

119 Ibid., 464.

${ }^{120}$ Fred A. Wilcox, Waiting for an Army to Die: The Tragedy of Agent Orange (New York: Random House, 1983), 13. See also Feeny and Allaway, "The Ecological Impact," 463-464. 
were afflicted by debilitating Agent Orange-related illnesses after the war. ${ }^{121}$

Considering that the hardest hit victims either died from their afflictions or were probably too ill to write memoirs, this is not surprising. The omission of any discussion of Agent Orange from veteran narratives, however, meant that readers would not be reminded of one of the most depressing consequences of the war for many of the troops who served there.

Although Legacies of Vietnam contained some positive findings, the authors of the study nevertheless concluded that "military duty in Vietnam had a negative effect upon post-military achievement."122 Although most Vietnam veterans engaged in some kind of educational training after leaving the military, only 22 percent were college graduates as of 1977. In comparison, 46 percent of non-veterans had graduated from college by that time, and non-veterans were more likely than veterans to have "pursue[d] post-graduate or professional training." $" 123$ The study also found that "in the competition for high level jobs, non-veterans [were] markedly more successful than veterans," and that the professional success of non-veterans was due to their superior educational backgrounds. ${ }^{124}$ Moreover, the "modest wage advantage" that white veterans held over their non-veteran peers was actually illusionary, for the veterans surveyed were, on average, older than the non-veterans. This age difference was evidently an important

${ }^{121}$ One veteran-author, Rod Kane, mentions at the end of his memoir that he has skin rashes that were likely caused by exposure to Agent Orange. Kane, Veteran's Day, 254-255.

${ }^{122}$ Legacies of Vietnam, 8.

123 Ibid., 13.

${ }^{124}$ Ibid., 7. 
factor, because when veterans were matched with non-veterans of the same age, their wage advantage disappeared. $^{125}$

Although the Legacies study found that military service benefited AfricanAmerican veterans in some ways, it nevertheless determined that many black veterans were faring badly in post-Vietnam America. The unemployment rate for black Vietnamera veterans "was three times that of white veterans," and even higher, 22 percent, for African Americans who served in Vietnam. ${ }^{126}$ Black Vietnam veterans had a high "career unemployment" rate, ${ }^{127}$ and African-American veterans were "less satisfied with their jobs than white veterans." 128 Although the study determined that African Americans who served in Vietnam had higher incomes than those who did not, the Legacies researchers found that black veterans nevertheless suffered a "drastic loss in real wages" in the late 1970 's. ${ }^{129}$

Despite the image of military service that provides young men with valuable job skills, few Vietnam veterans were prepared to re-enter the civilian economy when they left the military. ${ }^{130}$ Men who served in the infantry and other combat roles were especially lacking in "skills transferable to the civilian job market."131 Worse yet, the

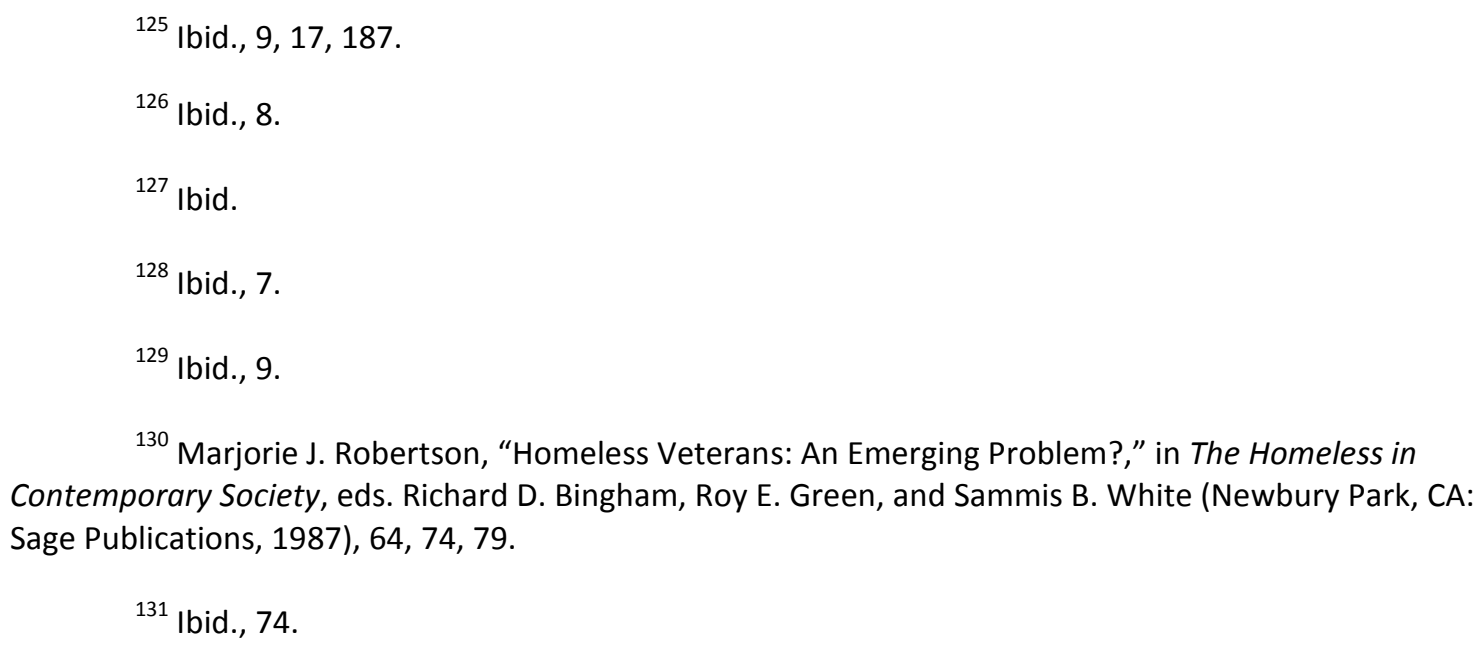


rapid deindustrialization of the American economy in the 1970's eliminated many of the jobs previously available to unskilled workers. As a result, scores of Vietnam veterans became unemployed after the war, which led in many cases to homelessness. African Americans, veterans included, were particularly hard hit by deindustrialization, which led to a rise in black homelessness. A disproportionate nonwhite presence in the infantry during the war was surely a factor in the appearance of young black and Hispanic veterans in the post-Vietnam-era homeless population. ${ }^{132}$

It is true that most Americans who served in Vietnam successfully re-entered civilian life after they came home, but the NVVRS and Legacies of Vietnam show that the postwar fate of Vietnam veterans was far from being an unambiguous success story. A dominant theme in veterans' narratives is the story of the veteran who initially encounters readjustment problems, but then recovers and goes on to achieve great professional success. This discrepancy between what veterans' narratives, and other sources, say about their postwar lives is rooted in the demographics of the veteran memoirists. Memoirists were disproportionately white and middle-class, and they generally entered the military with better educations than the average soldier who fought in Vietnam. When most memoirists came home, they, like many non-veterans, had a leg up on the majority of veterans who came from poor and working-class households and had comparatively poor educational backgrounds. Consequently, readers primarily learned about how Vietnam veterans fared after the war from authors who were better equipped to succeed in civilian life than the typical combat veteran.

${ }^{132}$ Kusmer, Down and Out, 239-247. 
Lewis Puller, Jr., went to Vietnam as a young, patriotic Marine Corps officer, but returned home a psychological and physical wreck. Only a few months after he assumed command of his infantry platoon, Puller stepped on a Vietcong booby trap that mutilated his hands and blew off both of his legs. Puller's memoir, Fortunate Son, chronicled his short, disillusioning tour in Vietnam, the long and painful recovery from his physical injuries, and his post-Vietnam battles with depression and alcoholism. Like many other Vietnam-veteran memoirs, Fortunate Son ends on a positive note, with Puller looking forward to moving on with his life, his troubles seemingly behind him. After Puller's book was published in 1992, his good fortune continued: Fortunate Son won a Pulitzer Prize, and Puller shared the stage with President Bill Clinton during a 1993 Memorial Day ceremony. The cover of Fortunate Son described the book as a story about "the healing of a Vietnam vet," and that seemed an apt description until early May 1994, when Puller, beset again by depression and substance abuse problems, killed himself in his Virginia home. ${ }^{133}$

Because Puller's homecoming story did not come to its sad end until after his book was published, the readers of Fortunate Son learned much about Puller's postVietnam life, but they did not get the full story. In several ways, veterans' narratives in general are like Puller's tragic story: they tell a lot, but not everything about the return of Vietnam veterans to America. Veterans' memoirs correctly explained to readers that soldiers who served in Vietnam encountered many hardships after they returned home, but they did not inform them that war veterans have always faced readjustment problems. In addition, evidence suggests that stories of abusive anti-war protestors and other

${ }^{133}$ Catherine S. Manegold, "Suicide of a Veteran, Amid Pain and Fame," The New York Times, 14 May 1994, 9. 
unfriendly homecoming experiences are at best exaggerated, if not completely inaccurate. Memoirs forthrightly acknowledged the psychological afflictions that many veterans faced, but the same accounts incorrectly suggested that most veterans eventually overcame their problems and moved on to success in civilian life.

It would be unfair to fault the veterans for not incorporating thoroughly researched histories of the Vietnam War and its aftermath into their memoirs. Most Vietnam veterans, like most other Americans, probably did not know that the veterans of World War II and earlier conflicts also had significant postwar readjustment problems. Veterans reported dubious stories of harassment by anti-veteran civilians not because they wanted to spread lies, but because their memories were distorted. Veterans' accounts of their postwar experiences are further proof that while their narratives are valuable resources for learning about the Vietnam War, they are not infallible. 


\section{CHAPTER SEVEN THE POLITCAL CONTENT OF VETERAN NARRATIVES}

In May 1985, the Asia Society sponsored a conference in New York City entitled, “The Vietnam Experience in American Literature." Academics, publishers, and representatives from other fields of scholarship spoke at the event, but the most important participants were writers, most of them Vietnam veterans, who had produced novels, memoirs, poetry, and oral histories about the war. Political scientist Timothy J. Lomperis explained in his published commentary on the proceedings of the conference, "Reading the Wind": The Literature of the Vietnam War, that similar conferences had been held earlier in the decade, but these events failed to live up to expectations. The organizers of these earlier conferences, he said, had set "modest agendas" and structured discussions around "manageable subtopics." But participants, according to Lomperis, had invariably discarded these plans in favor of pursuing chaotic, "grandiose" discussions about the "lessons" of the war. ${ }^{1}$ The 1985 Asia Society conference was divided into subtopics, such as "combat literature" and "fact and fiction in the literature," and from the outset its participants were warned not to repeat the mistakes of the past and veer into arguments about "the lessons of Vietnam.",

\footnotetext{
${ }^{1}$ Timothy J. Lomperis, "Reading the Wind": The Literature of the Vietnam War (Durham, NC: Duke University Press, 1987), 4.

2 Ibid., 5.
} 
From the moment the conference started however, it was clear that this warning would not be heeded. The keynote speaker, James Webb, Vietnam veteran, future U.S. Senator, and author of the semiautobiographical Vietnam War novel, Fields of Fire, began the conference by chastising American writers for romanticizing America's enemies during the war, and for ignoring the human rights abuses and expansionist policies of the Communist regime that had ruled all of Vietnam since 1975. He added that "our literature" had depicted Vietnam veterans as "men ... dragged into the war zone against their will, later as losers, finally as victims," when statistics and surveys showed that most veterans were well-educated homeowners who supported "the bombing of North Vietnam" and "the use of napalm," and had volunteered for military service and were "glad they served their country." Webb also stated that he believed in "the validity of our effort in Vietnam," and that only "our flawed government policy made the war unwinnable."4

At the time, Webb was a high-level official in the U.S. Department of Defense, and consequently, many at the conference regarded his speech unfavorably as "a partisan and political defense of the Reagan administration's interpretation of the war as a 'noble crusade.' " 5 W.D. Ehrhart, an author who joined the Vietnam Veterans Against the War (VVAW) after he came home from Southeast Asia, drew applause when he said that even if Webb's assessment of post-1975 Vietnam was correct, it did not change the fact that the war was "unspeakably evil and immoral."6 Another VVAW activist, Ron Kovic, the

\footnotetext{
${ }^{3}$ Ibid., 16-17.

${ }^{4}$ Ibid., 17. For all of Webb's speech see pages 13-19.

${ }^{5}$ Ibid., 6.
} 
author of the memoir, Born on the Fourth of July, said that Webb "was trying to undo everything that I and others had done," and "to negate my suffering, and the suffering of thousands and thousands of Americans and Vietnamese."7 Kovic went on to call what he saw as a Reagan-era revival of militarism as the "Nazification of my country," and speculated that "maybe Hitler is in the White House right now."

The heated politically and ideologically charged arguments that broke out throughout the rest of the conference, however, demonstrated that Webb was not alone in his feelings about the war and its aftermath. Veteran Frederick Downs, author of the memoir, The Killing Zone: My Life in the Vietnam War, agreed with Webb's contention that publishers in the immediate postwar years had been unwilling to publish Vietnam War books that were not sufficiently anti-war in tone. During a panel titled "Images of Asia and Asians in the Literature," veteran Al Santoli, the author of Everything We Had: An Oral History of the Vietnam War by Thirty-Three American Soldiers Who Fought It, loudly reiterated Webb's sentiments about Communist depredations in 1980's Southeast Asia, and asserted that the publishing industry refused to print anything that did not adhere to "the Ho Chi Minh point of view."

There was much conflict in the United States during the Vietnam War between so-called "hawks" and "doves" over whether the U.S. should end its costly military endeavor in Southeast Asia. After the shooting war in Vietnam ended, another "war"

\footnotetext{
${ }^{6}$ Ibid., 20.

${ }^{7}$ Ibid., 26.

${ }^{8}$ Ibid., 31.

${ }^{9}$ Ibid., 22, 72-73.
} 
began: the battle over how the Vietnam War would be remembered. ${ }^{10}$ As is evinced in “Reading the Wind," this battle perhaps reached its apex during the 1980's, with some arguing that the war should be seen as a "noble cause" derailed by traitorous anti-war demonstrators and weak-kneed politicians, while others saw the war as a huge and horrible mistake that should serve as a lesson against future military interventions. Though the battle over the nation's "collective memory" of the war gradually decreased in intensity as years passed, this struggle nevertheless continued long after the 1980's and into the present day. ${ }^{11}$

There is a reoccurring theme in Vietnam veteran personal narratives that these personal testimonies stand above the kind of rancor displayed at the 1985 Asia Society conference. Some veteran writers have asserted that their war stories and those of other veterans are nothing more than straightforward accounts of personal experiences. Philip Caputo states in the first paragraphs of his classic memoir, A Rumor of War, that his book “is simply a story about war," and "has nothing to do with politics, power, strategy, influence, national interests, or foreign policy." ${ }^{12}$ Tim O'Brien makes a similar point when he claims in his oft-quoted essay/short story, "How to Tell a True War Story," that a "true war story ... does not instruct, nor encourage virtue, nor suggest models of proper

\footnotetext{
${ }^{10}$ Philip K. Jason, ed., Fourteen Landing Zones: Approaches to Vietnam War Literature (lowa City, IA: University of lowa Press, 1991), xii.

${ }^{11}$ National politics is one arena of American life in which the Vietnam War remained a prominent topic long after the 1980's. Bill Clinton was criticized during and after his successful run for the presidency because he evaded the draft and opposed the war during his student days, and the Vietnam-era military service (or lack thereof) of candidates continued to be a reoccurring theme in ensuing presidential elections. Julia Bleakney argues in Revisiting Vietnam: Memoirs, Memorials, Museums, however, that the Vietnam War has faded from importance in the nation's collective memory since the 9/11 attacks, with World War II reassuming its position as the preeminent war in the nation's consciousness. Julia Bleakney, Revisiting Vietnam: Memoirs, Memorials, Museums (New York: Routledge, 2006), 26-29.

${ }^{12}$ Philip Caputo, A Rumor of War, New York: Holt, Rinehart and Winston, 1977; Owl Books, 1996), xiii.
} 
human behavior." ${ }^{13}$ In The Soldiers' Tale: Bearing Witness to Modern War, a book about twentieth-century war memoirs, Samuel Hynes perfectly sums up this prevalent attitude by stating that veterans' personal narratives do not engage in the polemics that surround wars and their aftermaths, but instead, "simply tell us what it is like ... They bear witness." 14

The arguments that took place at the 1985 conference suggest that many of the most prominent Vietnam veteran-writers were very much engaged in the struggle over the public memory of the war. Many veterans' narratives make overt political or ideological comments about the war and how it has been remembered. But all veterans who produced personal narratives, purposefully or not, affect collective memory of the war just by telling readers what they experienced in Vietnam. Even Caputo, O'Brien, and other veterans who want their works to exist outside the ongoing contest over history and memory become part of it because their narratives continue to influence large numbers of people.

Despite the prevalence of political and ideological elements in veteran narratives, relatively little attention has been paid to this important aspect of these works. The only exceptions are the several literary scholars who have basically contended that almost all veteran narratives represent powerful cases for why the Vietnam War (and warfare in general) was a horrible atrocity that should never be repeated. ${ }^{15}$ There is some truth to

\footnotetext{
${ }^{13}$ Tim O'Brien, "How to Tell a True War Story," in The Things They Carried: A Work of Fiction (New York: Houghton Mifflin, 1990; Mariner Books, 2009), 64-81.

${ }^{14}$ Samuel Hynes, The Soldiers' Tale: Bearing Witness to Modern War (New York: Allen Lane/The Penguin Press, 1997), 30.

${ }^{15}$ Examples of books that espoused this conception of veteran-authored Vietnam War literature include Thomas Myers, Walking Point: American Narratives of Vietnam (New York: Oxford University Press, 1988), 5-13, 26-31; Andrew Martin, Receptions of War: Vietnam in American Culture (Norman, OK:
} 
this argument, but it is overly simplistic and does not take into account the many nuances in veterans' statements and depictions of the war. Most of these scholars came to these conclusions by analyzing only a handful of veteran narratives, and their analyses usually made no distinctions between fiction and nonfiction.

After briefly identifying the dominant political and ideological messages about the war included in veteran narratives, this chapter will assess how influential print media, by selecting certain types of memoirs to review and rejecting others, helped to shape the public's collective understanding of the war. I will then address the question of to what extent the average veteran's views on the Vietnam War paralleled or deviated from that of the veterans who wrote memoirs about their experiences.

For the most part, veterans' memoirs offer an extremely negative interpretation of the war. A significant number are authored by individuals who overtly state their opposition to the war. An even larger number of memoirs represent various phenomena in ways that cast the war in a negative light in general. Yet, memoirists also are often unsympathetic, even hostile toward the civilian anti-war movement, and the authors suggest that they continued to hold traditional ideas about patriotism and pride in military service after their combat tours ended. A degree of ambiguity about the war is inherent in almost all of the veteran narratives. This would allow reviewers of the memoirs considerable leeway to emphasize one or the other aspect of the book they were appraising.

Which Vietnam memoirs influential periodicals chose to review, and the nature of the reviews themselves, played an important role in determining the success of a book 
and how many people would read it, which in turn would affect whether a particular book would have any significant impact on the collective memory of the war. A survey of veterans' narratives reviewed from 1967 to 2005 in three of the most prominent, nationally-read publications, the New York Times, the Washington Post, and Time, demonstrates that the books that got the most attention were those that portrayed the war in a generally negative manner. Prominent publications usually avoided books that represented the Vietnam conflict, as Webb and Reagan did, as a worthy and just undertaking that was undermined by poor military strategy and/or the actions of traitorous peace advocates. But such publications also ignored memoirs that espoused a more extreme, unambiguous anti-war message. The rare reviews of books that took clear left- or right-wing stances on the war were either negative, or at least neutral, when compared with how less-prominent (or more ideologically-oriented) periodicals dealt with the same works.

An analysis of the publishing history of veterans' memoirs is the best way to begin the discussion of how media outlets have elevated some types of these books over others. The first Vietnam veteran memoir published by a major company was Donald Duncan's 1967 book, The New Legions. ${ }^{16}$ Duncan went to South Vietnam in 1964 as a member of the Army's elite Special Forces, or “Green Berets," but during his eighteenmonth tour he gradually became convinced that the war was wrong. When he came home he left the military and joined the anti-war movement. Duncan was eventually hired by Ramparts, a New Left magazine, to serve as their military editor, and in February 1966 he authored an article about his Vietnam experiences for that publication

\footnotetext{
${ }^{16}$ Donald Duncan, The New Legions (New York: Random House, 1967).
} 
entitled "The Whole Thing Was a Lie!"17 Both the article and The New Legions, unlike many subsequent veteran narratives, were not written ostensibly to "tell it like was." Instead, they were political tracts (polemics) in which Duncan used his experiences to support his arguments against the war.

For the next seven years after The New Legions appeared in print, relatively few other veteran memoirs appeared until after the 1973 withdrawal of American troops from South Vietnam. The handful of memoirs that reached bookstores, like other types of Vietnam War books published during this period, ${ }^{18}$ usually fell into one of two categories: overtly anti-war pieces akin to The New Legions or titles that expressed support for the war. On the anti-war side were books such as Terry Whitmore's Memphis, Nam, Sweden: The Story of a Black Deserter $(1971)^{19}$ and A Hero's Welcome: The Conscience of Sergeant James Daly Versus the United States Army (1975). ${ }^{20}$

Representing the "pro-war" side were primarily books written by POWs who came home as staunch supporters of America's cause in Southeast Asia, such as James N. Rowe's Five Years to Freedom (1971), ${ }^{21}$ and Robinson Risner's The Passing of the Night: My

${ }^{17}$ Donald Duncan, “The Whole Thing Was a Lie!” Ramparts 4, no. 10 (February 1966), pp. 12-24.

18 Jeffrey Walsh, American War Literature, 1914 to Vietnam (New York: St. Martin's Press, 1982), 2; Zalin Grant, “Vietnam as Fable," The New Republic, 25 March 1978, 22-23.

${ }^{19}$ Terry Whitmore and Richard P. Weber, Memphis, Nam, Sweden: The Story of a Black Deserter (New York: Doubleday, 1971; reprint, Jackson, MI: University Press of Mississippi, 1997).

${ }^{20}$ James A. Daly and Lee Bergman, Black Prisoner of War: A Conscientious Objector's Vietnam Memoir (Lawrence, KS: University Press of Kansas, 2000), 107, 133, 148. Originally published as A Hero's Welcome: The Conscience of Sergeant James Daly Versus the U.S. Army (Indianapolis, IN: Bobbs-Merrill, 1975).

${ }^{21}$ James N. Rowe, Five Years to Freedom (Boston: Little, Brown, 1971; New York: Ballantine/Presidio Press, 2005). 
Seven Years as a Prisoner of the North Vietnamese (1973). ${ }^{22}$ Memoirs published in this era make up only a small fraction of the fifty-five most prominent veteran narratives, and not all of them garnered enough attention from critics, readers, or scholars to warrant wide circulation.

Perhaps veteran memoirs were scarce during this period because veteran-writers needed time after their tours ended to process their experiences and learn how to put them on paper. ${ }^{23}$ Some veteran-memoirists, and other writers, claimed that many veteranauthored books went unpublished in the immediate postwar years because most publishers rejected manuscripts that were not sufficiently "anti-war" in content. ${ }^{24}$ Publishers Weekly reported in the late 1960's that many publishers were against the war, but did not indicate that anyone rejected books simply because they were not "antiwar."25 Other commentators, however, claim that publishing companies generally avoided any type of Vietnam War book during these years because they believed that the American public was sick of the war and would not buy such books. ${ }^{26}$ Various scholars

\footnotetext{
${ }^{22}$ Robinson Risner, The Passing of the Night: My Seven Years as a Prisoner of the North Vietnamese (Old Saybrook, CT: Konecky \& Konecky, 1973).

${ }^{23}$ Merritt Clifton, ed., Those Who Were There: Eyewitness Accounts of the War in Southeast Asia, 1956-1975, and Aftermath (Paradise, CA: Dustbooks, 1984), viii.

${ }^{24}$ Clifton, Those Who Were There, ix; Lomperis, "Reading the Wind," 22; Brian Mitchell, "Jonah Speaks," Review of Chained Eagle: The Heroic Story of the First American Shot Down Over North Vietnam by Everett Alvarez and Anthony S. Pitch, The National Review, 19 March 1990, 51; Edwin McDowell, "Publishing: Vietnam Rediscovered," The New York Times, 2 Dec. 1983, C25. A few early veteran-authors said that publishers rejected their writings because of their strong anti-war sentiments. Caroline Slocock, "Winning Hearts and Minds: The Ist Casualty Press," Journal of American Studies 16, no. 1, (1982): 111112.

25 "Publishers and Librarians Sign Vietnam Protest," Publishers Weekly 193 (1 Jan. 1968), 24-25; “Publishers Rally in Support of Vietnam Moratorium," Publishers Weekly 196 (27 October 1969), 36-37.

${ }^{26}$ Lomperis, "Reading the Wind," 45; Edwin McDowell, "Publishing," C25; "4 Writers Try to Make Sense of the Vietnam-Book Boom," The New York Times, 4 August 1987, C17; Slocock, "Winning Hearts and Minds," 112-114; Grant, "Vietnam as Fable," 22.
} 
and commentators support this notion by referring to this relatively brief postwar period as a time when Americans collectively tried to put the war behind them and forget it ever happened. $^{27}$

The dearth of published veteran narratives, whatever caused it, ended in the late 1970's. This change began with the great critical and popular success achieved by Kovic's 1976 memoir, Born on the Fourth of July. ${ }^{28}$ Caputo's A Rumor of War was released to similar acclaim a year later. In 1978, Hollywood released Coming Home and The Deer Hunter, further signaling a growing willingness to confront the war. ${ }^{29}$ During the 1980's, this renewed interest in the conflict reached a crescendo, as Vietnam during this decade suffused movies, television shows, ${ }^{30}$ political discourse, and other aspects of American culture. ${ }^{31}$ Eager to feed off this trend, publishers put out hundreds of veteranauthored memoirs, novels, and oral histories over the next couple of decades. By the early 1990's, bookstores contained "Vietnam shelves" in their history sections. ${ }^{32}$ A large percentage of the books on these shelves were authored by veterans.

${ }^{27}$ Lomperis, "Reading the Wind," 4; Peter Marin, "Coming To Terms with Vietnam," Harper's, Dec. 1980, 41; Alf Louvre and Jefferey Walsh, ed., Tell Me Lies About Vietnam: Cultural Battles for the Meaning of the War (Philadelphia: Open University Press, 1988), 5-6; James C. Wilson, Vietnam in Prose and Film (Jefferson, NC: McFarland \& Company, 1982), 1-2.

${ }^{28}$ Ron Kovic, Born on the Fourth of July (New York: McGraw Hill, 1976; reprint, New York: Akashic, 2005); Clifton, Those Who Were There, x.

${ }^{29}$ Peter Biskind, “The Vietnam Oscars," Vanity Fair, March 2008, 266.

${ }^{30}$ Eric T. Dean, Jr., Shook Over Hell: Post-Traumatic Stress, Vietnam, and the Civil War (Cambridge, MA: Harvard University Press, 1997), 19-21; Louvre and Walsh, Tell Me Lies About Vietnam, 2.

${ }^{31}$ Marilyn B. Young, The Vietnam Wars, 1945-1990 (New York: HarperCollins, 1991), 314-316, 328-329.

32 Jason, ed., Fourteen Landing Zones, xi. 
The great majority of the veteran memoirs published since at least 1990 have been what one scholar calls "Vietpulp": cheap paperback novels, memoirs, biographies, and popular histories of low literary quality that often focus on the exploits of elite combat units. $^{33}$ Such books are mostly apolitical, as they usually focus only on describing combat situations and do not often address any of the larger issues of the war. With few exceptions, Vietpulp-type memoirs were not award-winners or bestsellers and were not reviewed in the most influential periodicals or consulted by scholars. Only a handful of books that could be labeled "Vietpulp" deserve a place among the most prominent veteran memoirs.

Most of the prominent memoirs are ostensibly, and often expressly, apolitical; they supposedly just "tell it like it was" and nothing more. The same goes for the most popular oral histories. But unlike most Vietpulp, the majority of these books are actually far from apolitical. Eleven memoirists, all of them former POWs, basically express unambiguous support for the war. These men depict the war as clear struggle between good and evil. This is understandable considering that they were held in poor conditions and sometimes tortured by their North Vietnamese captors. Such authors lauded President Richard Nixon and his controversial Vietnam policies and portrayed American peace protestors as dupes of Communist propaganda or outright villains.

The most dominant, obvious message in the veteran narrative genre, however, is that the war was, at best, a horrific mistake and, at worst, a terrible crime. One of the most common themes in the genre is the story of the patriotic young American who goes to Vietnam and has nightmarish and disillusioning experiences that turn him against the

\footnotetext{
${ }^{33}$ Philip D. Beidler, Late Thoughts on an Old War: The Legacy of Vietnam (Athens, GA: University of Georgia Press, 2004), 123-138.
} 
war. This theme began with Born on the Fourth of July, continued with A Rumor of War, and was subsequently repeated in many other narratives. Moreover, a smaller number of well-known memoirs, such as Tim O'Brien's If I Die in a Combat Zone, Box Me Up and Ship Me Home, are about authors who opposed the war from the beginning, ended up in Vietnam anyway and had experiences there that reinforced their opposition to the conflict. $^{34}$ Kovic, Caputo, and other important memoirists joined the VVAW or other anti-war groups when they came home from Southeast Asia. Several others did not participate in the peace movement but were openly sympathetic with its actions. ${ }^{35}$

Memoirists who turned against the war at some point were unambiguous in expressing their antipathy towards the war. O'Brien wrote in If I Die that he "was persuaded the war was wrong" before he left for Vietnam and was just as persuaded when he was writing his book years later. ${ }^{36}$ O'Brien calls himself a "coward" for going to Vietnam even though he opposed the war. ${ }^{37}$ Several other memoirists, such as Tobias Wolff and Bruce Weigl, also suggest that the actions of those who avoided military

${ }^{34}$ Tim O'Brien, If I Die in A Combat Zone, Box Me Up and Ship Me Home (New York: Delacorte Press, 1973; Delta, 1989; Other examples include Tobias Wolff, In Pharoah's Army: Memories of the Lost War (New York: Alfred A. Knopf, 1994); And a Hard Rain Fell: A G.I.'s True Story of the War in Vietnam (New York: Macmillian, 1985); Larry Heinemann, Black Virgin Mountain: A Return to Vietnam (New York: Doubleday, 2005).

${ }^{35}$ Examples of veteran memoirists who joined the anti-war movement when they returned home include Caputo, A Rumor of War, xvi, 342; W.D. Ehrhart, Passing Time: Memoir of a Vietnam Veteran Against the War (Amherst, MA: University of Massachusetts Press, 1995. (Originally published as Marking Time, New York: Avon Books, 1986) 82-97; Rod Kane, Veteran's Day: A Combat Odyssey (New York: Orion; Pocket Book, 1990), 120-174; Kovic, Born on the Fourth of July, 147-181; Michael Norman, These Good Men: Friendships Forged from War (New York: Crown Publishers, 1989), 99-100; Nathaniel Tripp, Father, Soldier, Son: Memoir of a Platoon Leader in Vietnam (South Royalton, Vermont: Steerforth Press, 1996), 228.

\footnotetext{
${ }^{36}$ O’Brien, If I Die, 17.

${ }^{37}$ Ibid, 66.
} 
service reflected bravery, or at least intelligence ${ }^{38}$ One memoirist calls the war "wrong, stupid, and futile, ${ }^{, 39}$ and admits that his Vietnam experiences made him hate the United States to the extent that he considered moving to another country. ${ }^{40}$ Another says that while other Vietnam veterans he knows "would carry a gun again if the call came," he would instead "shoot the caller." 41

Reinforcing these direct statements against the war are the negative depictions of various aspects of the conflict that veterans included in their narratives. Rather than romanticizing their combat experiences, many veterans offered an image of the battlefield that focused on mutilated corpses, horrible injuries, and the fear that gripped men engaged in combat. The particular kind of war they fought in Vietnam, with its booby traps, hit-and-run ambushes, and civilian casualties, was described as extraordinarily frustrating, and often the tactics used by the American military in this struggle were depicted as futile or nonsensical. Adding to the frustration were the civilians, who were represented as either enemy collaborators or greedy opportunists, and their allies in the South Vietnamese military who were supposedly too stupid or cowardly to fight their own battles. Finally, a large number of veterans acknowledged that they were plagued by post-traumatic stress disorder and other combat-related psychological problems long after their tours in South Vietnam had ended.

\footnotetext{
${ }^{38}$ Tobias Wolff, In Pharoah's Army: Memories of the Lost War (New York: Alfred A. Knopf, 1994), 8, 117-128; Bruce Weigl, The Circle of Hahn: A Memoir (New York: Grove Press, 2000), 131. Others include Bob Kerrey, When I Was a Young Man: A Memoir (New York: Harcourt, 2002), 136; Ketwig, And a Hard Rain Fell, 116.

${ }^{39}$ Tripp, Father, Soldier, Son, 85.

${ }^{40}$ Ibid., 201.

${ }^{41}$ Norman, These Good Men, 9.
} 
Negative depictions of the war were not limited to the narratives of veterans who express unbridled antipathy towards the Vietnam conflict. In a 1986 Journal of American History review essay, historian George C. Herring identified two veteran memoirs, David Donovan's Once a Warrior King: Memories of an Officer in Vietnam, and James R. McDonough's Platoon Leader, as "revisionist" in content. ${ }^{42}$ Donovan echoes the rhetoric of Reagan-era conservatives in his memoir when he writes of the expansionist policies of the post-1975 Vietnamese government and blames the "perfidious" American public for the defeat of the U.S. military in Vietnam. ${ }^{43}$ As Herring notes in his article, both Donavan and McDonough also paint, at times, a bleak picture of the war. ${ }^{44}$ Donovan suggests in his books that the average GI in Vietnam held all Vietnamese in contempt $;{ }^{45}$ McDonough wrote of soldiers driven insane by combat and American officers who hid from battle; ${ }^{46}$ both memoirists portray South Vietnamese government officials and military men as cruel or incompetent. ${ }^{47}$

There are other elements of veterans' memoirs that seemingly contradict their negative portrayal of the war. Even though a number of the best-known memoirists either sympathized with the anti-war movement or actually participated in it themselves, the general portrayal of civilian anti-war activists in veteran narratives is unfavorable.

${ }^{42}$ George C. Herring, "Vietnam Remembered," Journal of American History 73, no. 1 (June 1986), 161.

${ }^{43}$ David Donovan, Once a Warrior King: Memories of an Officer in Vietnam (New York: McGraw Hill, 1985), 307-308.

${ }^{44}$ Herring, "Vietnam Remembered," 157-158, 161.

${ }^{45}$ Donovan, Once a Warrior King, 28-33.

${ }^{46}$ James R. McDonough, Platoon Leader (Novato, CA: Presidio, 1985), 17-19, 24-26.

${ }^{47}$ Ibid., 76, 114-115; Donovan, Once a Warrior King, 46, 98, 123-127, 133. 
Americans who opposed the war in Vietnam are most commonly depicted by memoirists as either "hippies" or ordinary people who harass and insult soldiers returning from Vietnam. Even some of the veterans who sympathized with or participated in the antiwar movement offer harsh depictions of nonveteran anti-war participants. For example, former Army nurse Lynda Van Devanter says in her memoir that while still in Vietnam she observed a Thanksgiving Day fast in 1969 to show her solidarity with anti-war protestors back in the United States. Later in her book, Van Devanter relates that on the day she returned to the U.S. from Vietnam, a man fitting the description of a stereotypical anti-war "hippie" called her an "Army pig" and spat on her. ${ }^{48}$

Claims that soldiers and veterans were hated and abused in the Vietnam era are not supported by facts. The American public, including opponents of the war, were sympathetic to both groups, and there is no credible evidence that returning GIs were ever spat on by protestors. Memoirists' depictions of the anti-war movement are also misleading because some, like Van Devanter, suggest that most opponents of the war were hippies or student radicals. This was never the case. ${ }^{49}$ From its beginnings the antiwar movement was composed of a diverse array of groups and individuals. ${ }^{50}$ Participants in the 1967 March on the Pentagon "included . . middle-class liberals, student radicals,

${ }^{48}$ Lynda Van Devanter with Christopher Morgan, Home Before Morning: The Story of an Army Nurse in Vietnam (New York: Beaufort Books, 1983), 159, 211. Other examples of veterans who worked in, or sympathized with the anti-war movement, but also offered negative portrayals of the movement included Norman, These Good Men, 99-100; Ketwig, And a Hard Rain Fell, 68, 77, 116, 151-152; Heinemann, Black Virgin Mountain, 27, 35; Ehrhart, Passing Time, 7, 88-97.

49 This depiction of the anti-war movement harkens back to the media's portrayal of the movement during much of the war. In its coverage of peace demonstrations, the media inevitably singled the most newsworthy participants: "flamboyant" and militant protestors who waved the Vietcong flag and did and said other provocative things. Todd Gitlin, The Whole World is Watching: Mass Media in the Making \& Unmaking of the New Left (Berkeley, CA: University of California Press, 2003), 181-183.

${ }^{50}$ Terry Anderson, The Movement and the Sixties (New York: Oxford University Press, 1995), 124, $171,178$. 
hippies, civil rights workers, black power advocates, Vietnam veterans, [and] even some federal workers." the war lasted. On October 15, 1969, millions of Americans took "a one-day pause in their usual business" to observe the "Moratorium" against the war. ${ }^{52}$ Opposition to the war was "so mainstream" in its final years that "establishment" Democratic politicians, such as Senators Edward Kennedy and Edmund ("Ed”) Muskie, were its most conspicuous critics. $^{53}$

Many memoirists, including those who clearly loathed the war, indicate that they are proud of their service, enjoyed some aspects of their combat tours, and continue to hold traditional ideas about patriotism and the value of military service. Caputo asserts in the prologue to A Rumor of War that "anyone who fought in Vietnam . . . will have to admit he enjoyed the compelling attractiveness of combat." 54 He adds that "nostalgia" for his own tour prevented him from hating the war as much as others did who worked in the anti-war movement. ${ }^{55}$ Two different memoirists who each met with Vietcong and North Vietnamese Army veterans years after the war ended, say that despite their mostly negative feelings about the conflict, they were nevertheless still rankled by their former adversaries' boasts about their victory over America. ${ }^{56}$ Lewis Puller, Jr., who lost his

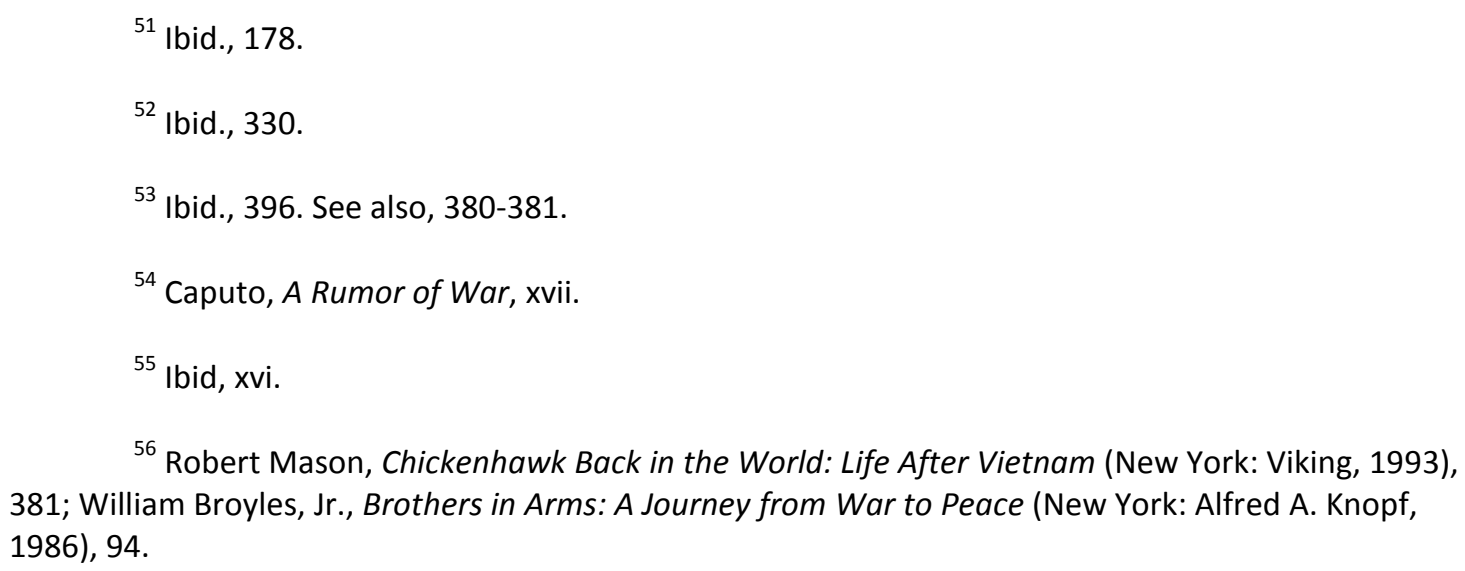


legs in Vietnam, was greatly disillusioned about the war and the military even before his injury, and he was tempted to join the VVAW activists who threw their medals over the fence in front of the Capitol building in 1971. Puller could not bring himself to engage in this form of protest, because those medals and what they represented were still too dear to him to throw away. ${ }^{57}$

Although many veteran narratives depict the war in a negative light and contain unambiguous statements against the war, Marine Corps veteran W.D. Ehrhart's four memoirs are particularly noteworthy for the clear anti-war message they present.

Ehrhart's first volume, Vietnam-Perkasie: A Combat Marine Memoir, covers his tour in Vietnam, ${ }^{58}$ while the subsequent memoirs deal with his postwar experiences. Ehrhart joined the Marines in 1966 as a patriotic young man who wanted to help protect South Vietnam from Communist aggression, but thirteen months of combat gradually eroded the values that had led him to volunteer. In his second memoir, Passing Time: Memoir of $a$ Vietnam Veteran Against the War, he explains that his feelings about the war reached a turning point in 1971, when the U.S. government's secret history of the Vietnam War, the Pentagon Papers, became public. These documents convinced Ehrhart that the war was not a mistake, as he previously believed, but was instead a "deliberate attempt to hammer the world by brute force into the shape perceived by vain, duplicitous power brokers."59 Ehrhart was outraged and radicalized by these revelations, and he joined the anti-war

${ }^{57}$ Lewis B. Puller, Jr., Fortunate Son (New York: Grove Weindenfeld, 1991), 262-263.

${ }^{58}$ W.D. Ehrhart, Vietnam-Perkasie: A Combat Marine Memoir (Jefferson, NC: McFarland, 1983; reprint, Amherst, MA: University of Massachusetts Press, 1995).

${ }^{59}$ Ehrhart, Passing Time, 172. 
movement soon afterwards, determined to stop the war that had turned him into, in his own estimation, a "murderer."60

Ehrhart's memoirs do not simply convey the message that the Vietnam War was wrong, but, rather, that warfare itself is fundamentally immoral. He has candidly stated that his books are "tool[s] for political education," and that the goal of his writing is to prevent future wars and spare future generations the horrors he witnessed in Vietnam. ${ }^{61}$ The broad scope of Ehrhart's goals and concerns is evident in many of his works, including Passing Time, which includes a chapter-long radical interpretation of United States history. Through a reconstructed discussion between himself and another VVAW activist, Ehrhart presents American history as a long series of injustices, from the expulsion of Native Americans from their lands by white settlers, to the U.S. government's Cold War policies in Latin America and Asia. ${ }^{62}$ Ehrhart states that these events show that the United States has always acted out of complete self interest, and has never cared "about freedom or justice or democracy for anybody.",63

Although Ehrhart's books have not done well commercially, his work is constantly cited by scholars interested in the Vietnam War and the literature produced by American veterans of the conflict. In the foreword to Ehrhart's fourth memoir, Busted: A Vietnam Veteran in Nixon's America, H. Bruce Franklin writes that "some consider

${ }^{60}$ Ibid., 175.

${ }^{61}$ Ronald Baughman, interview with W.D. Ehrhart (6 June 1991), in Ronald Baughman, ed., Dictionary of Literary Biography Documentary Series, vol. 9, American Writers of the Vietnam War (Detroit, MI: Gale Research Inc., 1991), 72. At the 1985 Asia Society conference on Vietnam War literature mentioned in this chapter's introduction, Ehrhart announced that his chief motive in writing was to "affect the course of [his] country." Lomperis, "Reading the Wind," 32.

${ }^{62}$ Ehrhart, Passing Time, 177-184.

63 Ibid., 181. 
[Ehrhart] the preeminent figure in this literature----treasured for his nonfiction, enormously influential as the foremost anthologist of Vietnam War poetry, and himself unsurpassed as a poet." ${ }^{64}$ Franklin goes on to speculate that Ehrhart is not better known outside academic circles because he rejects both the conservative reinterpretation of the war as a "noble cause" and its "liberal alternative," the idea that the war was a "horrible mistake." ${ }^{65}$ Ehrhart's position on the war, that it was engendered by the purposeful actions of "power brokers", is, Franklin argues, unacceptable to those in control of "corporate publishing and the major media." 66 The leaders of these industries, he claims, are akin to the power brokers who planned and carried out the war, and are unwilling to disseminate ideas about the conflict that diverge from a moderate viewpoint. ${ }^{67}$

Franklin's theory may seem farfetched, but it is partly supported by an analysis of how The New York Times, The Washington Post, and Time magazine have dealt with veteran memoirs over the decades. This analysis shows that these prominent media outlets, which are read by millions of Americans, were unwilling to review most veteran narratives that conveyed an explicit anti-war message, and the few such books that were reviewed were given unfavorable or neutral receptions. Of the three periodicals surveyed, only Time reviewed Duncan's The New Legions. That review was only one paragraph long, and its author dismissively ended the piece by saying that "the book says as much about the author's state of mind as about Viet Nam."68 Strangely, the Time

\footnotetext{
${ }^{64}$ W.D. Ehrhart, Busted: A Vietnam Veteran in Nixon's America (Amherst, MA: University of Massachusetts Press, 1995), xi.

${ }^{65}$ Ibid., xviii.

${ }^{66}$ Ibid., $x x$.

67 Ibid.
} 
reviewer made no reference to the political content of Duncan's hyper-political book, but he sarcastically noted that Duncan worked for "the anti-almost-everything magazine Ramparts." ${ }^{\text {,69 }}$ Ehrhart's books were rarely reviewed by this group of publications. The one exception, a short 1995 Washington Post review of Busted that was mostly positive, nevertheless ended with the comment: "It's easy to laugh along with Ehrhart, but hard to derive from his tale any lasting thoughts.",70

It is possible to see what is missing from media coverage of anti-war memoirs by looking at how The Nation, a left-leaning publication, dealt with such books. In 1967, The Nation reviewed The New Legions at length, and its reviewer properly highlighted the polemical nature of the book. ${ }^{71}$ In 1975 , more influential publications ignored $A$ Hero's Welcome, the memoir of James Daly, an African-American onetime POW who, while still in North Vietnam, joined a group of anti-war prisoners who called themselves the "Peace Committee." A Hero's Welcome was reviewed in The Nation, however, and its reviewer said that the book was written "with humor and sensitivity," and that it gave Americans "a rare close-up of the national enemy we spent a decade hating and killing."72 The reviewer also hinted at a possible reason why Daly’s book did not receive much attention, stating that it "contradicts nearly everything the American people were

68 "Books: Viet Nam in Print," Time, 17 Nov. 1967, 116.

69 Ibid.

${ }^{70}$ David Greenberg, "Nonfiction," Review of Busted: A Vietnam Veteran in Nixon's America by W.D. Ehrhart, The Washington Post, 24 Dec. 1995, X04.

${ }^{71}$ Alan Samuels, "I Quit! From Solo to Chorus," Review of The New Legions by Donald Duncan, The Nation, 26 Sept. 1967, 284-285.

72 Roger Neville Williams, "What Sergeant Daly Saw," Review of A Hero's Welcome: The Conscience of Sergeant James Daly vs. The United States Army by James A. Daly and Lee Bergman, The Nation, 27 Dec. 1975, 699. 
told about the [American POWs] by Nixon and his spokesmen, the Pentagon, and the television networks during the war."73 In 1995, The Nation printed a laudatory, lengthy review of Ehrhart's Busted, noting that the "the singular achievement" of the book is that, while providing a personal perspective on the Vietnam conflict, also addresses the larger, complicated issues surrounding the war, including its "complex link to U.S. geopolitical ambitions."74

Franklin, however, was mistaken in suggesting that the media was only biased against books about the war that expressed leftist or radical anti-war sentiments. The three prominent media outlets surveyed also showed a bias against veteran memoirs that expressed conservative or right-wing views of the war. This bias is best illustrated by examining how The National Review, the leading conservative magazine in the United States, covered these types of books. Former POW Everett Alavarez's memoir, Chained Eagle: The Heroic Story of the First American Shot Down over North Vietnam, was not reviewed by the New York Times, the Washington Post,${ }^{75}$ or Time, but it was afforded a glowing review in The National Review. The reviewer proclaimed that "every American" should read Chained Eagle and other POW memoirs that similarly exude patriotism and denounce the anti-war movement, even if Hollywood, in his estimation, avoided such Vietnam War stories. ${ }^{76}$ A few years earlier, The National Review praised another conservative-minded memoir, In Love and War: The Story of a Family's Ordeal

\footnotetext{
73 Ibid.

${ }^{74}$ Michael Uhl, "On the Lam from Vietnam," Review of Busted: A Vietnam Veteran in Nixon's America by W.D. Ehrhart, The Nation, 18 Sept. 1995, 286.

${ }^{75}$ The Washington Post did not review Chained Eagle, but it did publish an article about Alvarez at the time his book was released. Sue Anne Pressley, "Catching Up With Life: The Return of Everett Alvarez," The Washington Post, 12 Nov. 1989, F1, F8-F9.

${ }^{76}$ Brian Mitchell, “Jonah Speaks," 50.
} 
and Sacrifice during the Vietnam Years, co-written by former POW James Stockdale and his wife, Sybil. ${ }^{77}$ The Times $^{78}$ and the Post reviews of the book were mostly positive, but far more neutral in tone, although, the Post reviewer does flippantly suggest that the Stockdales, who both endured terrible hardships during James' captivity, "loved" the war. $^{79}$

The engagement of veteran-writers in the struggle for the collective memory of the Vietnam War is on display in their memoirs, many of which include direct statements about the larger issues surrounding the war. Even veterans who do not make such statements became involved in this memory battle as soon as their experiences were published, because their portrayals of the war, whether meaning to or not, inevitably affected readers' conceptions of the conflict. The overall depiction of the war that memoirists conveyed to their readers was overwhelmingly negative. The same veterans, however, are often proud they served, say some aspects of their combat tours were positive, and express animosity towards the anti-war movement. Books that convey these messages are the majority in the ranks of the most popular veterans' narratives partly

${ }^{77}$ Jeffrey Hart, "Years of the Fish," Review of In Love and War: The Story of a Family's Ordeal and Sacrifice During the Vietnam Years by James and Sybil Stockdale, The National Review, 3 May 1985, 52-53. The Wall Street Journal, another conservative publication, also gave the Stockdales' book a favorable review. The Journal's reviewer said In Love and War "should be read widely at a time when our nation is regaining an open spirit of love of country that some believed had been eclipsed forever." Edmund Fuller, "A POW's Story," Review of In Love and War by James and Sybil Stockdale, The Wall Street Journal, 9 Oct. 1984, 26.

${ }^{78}$ Kevin Buckley, "Nonfiction," Review of In Love and War by James and Sybil Stockdale, The New York Times, 28 April, 1985, BR25.

79 Duncan Spencer, "Two Paths of Glory," Review of In Love and War by James and Sybil Stockdale, The Washington Post, September 23, 1984, 233. Stockdale later ran as the running-mate of Independent candidate H. Ross Perot in the 1992 presidential election. 
because editors and the media select them over works that espouse overtly left- or rightwing political messages.

Interestingly, researchers for two separate government studies in the late 1970's found that Vietnam veterans as a whole also hold similarly complex, contradictory feelings about the war. The first government study, Myths and Realities: A Study of Attitudes Toward Vietnam Era Veterans, released in 1980, found that "on balance, Vietnam era veterans believe our military involvement in Vietnam was a mistake," ${ }^{\circ 0}$ and that 59 percent agreed with the idea that American "troops were asked to fight a war [they] could never win." 71 percent of the veterans surveyed said that the statement, "I found I actually liked the thrill of being in a war," 82 did not correspond to their own feelings at all, while only 5 percent said it matched their feelings "very closely." 83 The negative tone of these results was, in some respects, echoed in the surveys of veterans taken as part of the second study, Legacies of Vietnam: Comparative Adjustment of Veterans and Their Peers, which was released in 1981. Almost 43 percent of the veterans surveyed in this study said they opposed the war while serving in Vietnam, and 13.5 percent said they were neither for nor against the conflict because they did not understand it. Finally, 44.2 percent of the Legacies of Vietnam veterans believed that the war had "a negative effect . . . on the Vietnamese." 84

\footnotetext{
${ }^{80}$ Myths and Realities: A Study of Attitudes Toward Vietnam Era Veterans (Washington: United States Government Printing Office, 1980), 53.

${ }^{81}$ Ibid., 60.

${ }^{82}$ Ibid., 17, 21.

83 Ibid.

${ }^{84}$ Legacies of Vietnam: Comparative Adjustment of Veterans and their Peers (Washington: United States Government Printing Office, 1981), 29.
} 
Closer examination of these studies shows that veterans' feelings about their wartime experiences were not all negative. Myths and Realities concluded that most respondents were proud to be Vietnam veterans, were glad that they had served their country, would do so again if asked, ${ }^{85}$ and "rejected the statement that "it is shameful what my country did to the Vietnamese people." "86 These results indicated, according to the study's authors, that veterans "remain surprisingly patriotic," 87 and that "the representation of these veterans as consumed by guilt . . . and ashamed to be recognized as Vietnam veterans . . . is a myth." ${ }^{88}$ As for Legacies of Vietnam, although its authors thought it significant "that nearly six out of ten Vietnam veterans were participating in a war which they either opposed . . or did not understand," this still meant that 43.6 percent said they supported the war while in Vietnam. ${ }^{89}$ Vietnam veterans were more likely to have supported the war than either nonveterans, or veterans who served during the war years, but not in Vietnam. These latter two groups were also "substantially more likely" to "perceive a negative effect of the war on the Vietnamese" than Vietnam veterans. $^{90}$

These studies suggest that most veterans, like most popular veteran-memoirists, do not hold extreme positions on war-related issues. Ordinary veterans, like the small minority of their population that produced personal narratives, came home from

\footnotetext{
${ }^{85}$ Myths and Realities, 16, 25.

${ }^{86}$ Ibid., 16.

${ }^{87}$ Ibid., 25.

${ }^{88}$ Ibid., 16.

${ }^{89}$ Legacies of Vietnam, 29.

90 Ibid.
} 
Southeast Asia with complex, contradictory feelings that could not be clearly ascribed to one side or the other in the myriad debates concerning the war. The most successful memoirs, then, may have owed some of their popularity to decisions made by editors and reviewers, but the messages they conveyed were nevertheless reflective of veterans' views in general. The concurrence of the two groups' opinions is probably related to the fact that the majority of memoirists had Vietnam experiences similar to those of typical combat soldiers. The authors' backgrounds may have been exceptional in many respects, but they also went through bewildering combat tours that left them with ambiguous outlooks on the war. 


\section{CHAPTER EIGHT}

\section{CONCLUSION}

When the American Civil War ended in 1865, the memories of the soldiers who fought in it--Union and Confederate alike - seemed, in the words of historian Gerald F. Linderman, to go into a kind of "hibernation" for the ensuing fifteen years. ${ }^{1}$ These men had witnessed unspeakable carnage and suffered great privations, and many appeared to just want to forget all they had been through when they finally made it home. The veterans' collective silence during these fifteen years was abetted by a general feeling that the nation should move on and leave the horrors of the preceding years behind it. The 1880's, however, brought a great revival of interest in the Civil War. The public craved information about the conflict, and more ex-soldiers wanted to tell their stories. In the last two decades of the century, the wartime narratives of thousands of northern and southern veterans were recorded in memoirs, magazines, and "formal papers" presented at the meetings of local veterans' organizations. ${ }^{2}$ Although many Americans became fascinated with the Civil War in the 1880's, few “wanted to recollect the horror or the meaning of the war."3 Veterans, David W. Blight explains, participated in this selective

\footnotetext{
${ }^{1}$ Gerald F. Linderman, Embattled Courage: The Experience of Combat in the American Civil War (New York: The Free Press, 1987), 266-274; David W. Blight, Race and Reunion: The Civil War in American Memory (Cambridge, MA: Belknap/Harvard University Press, 2001), 149-150.

${ }^{2}$ Blight, Race and Reunion, 170-189.
} 
remembering by "clean[ing] up the battles and the campaigns of the real war, render[ing] it exciting and normal all at once.” ${ }^{4}$ By focusing on glorified recollections of combat and eschewing "the political meanings" of the war, especially its racial underpinnings, the nation moved closer towards sectional reconciliation as the century drew to a close. Another consequence of this reformulation of Civil War memory was a rebirth of militarism. Men who had decried the horrors of war as soldiers in the 1860's, extolled it in the 1890 's as a cure for the "softness" and materialism supposedly destroying American society during an era marked by massive urbanization and industrialization. Consequently, when war broke out between the United States and Spain in 1898, thousands of young men reared on romantic tales of Civil War heroics eagerly signed up for a chance at battlefield glory. ${ }^{5}$

A similar "hibernation" period followed America's defeat in Vietnam. There was a widespread sentiment throughout much of the 1970's that the country needed to forget the painful tribulations of the Vietnam era and look to the future. This all changed in the 1980's. Americans during the Reagan era suddenly became interested in "all things Vietnam," and book publishers, filmmakers, and even politicians eagerly fed the demand. Similar to the Civil War revival of a century earlier, much of the cultural material related to "Vietnam" produced in this 1980's depicted the war and its aftermath unrealistically and avoided or misrepresented its political meanings. Some representations, such as the film Platoon, winner of the 1986 Academy Award for Best Picture, took serious approaches to the war. But such renderings of the conflict were outweighed by

\footnotetext{
3 Ibid., 181.

${ }^{4}$ Ibid., 182-183.

${ }^{5}$ Linderman, Embattled Courage, 275-297.
} 
cartoonish Vietnam-related action movies, comic books, and pulp novels, and television shows. A new genre of films, with Rambo: First Blood Part II at the forefront, focused on the exploits of Vietnam veterans sent back to Southeast Asia to rescue American POWs. On television, the popular series the A-Team chronicled the adventures of four former Vietnam War commandos who travelled America helping the unfortunate and fighting injustice.

Most Vietnam-veteran memoirists, however, did not participate in the sanitizing or trivializing of the war in which they fought. Vietnam-veteran authors wrote of bulletshattered limbs, exposed intestines, slain women and children, and the terror experienced by soldiers under fire. While dealing forthrightly with the brutalities of war, the veteran narratives also exposed the racist and sexist attitudes held by many GIs in Vietnam. And all of this was rendered in graphic, vulgar, sometimes obscene language that is a far cry from the "purple prose" issued by many of the Vietnam authors' Civil War predecessors. ${ }^{6}$ Also unlike Civil War veterans, Vietnam memoirists did not shy away from the larger issues surrounding the war. The latter generation of veterans candidly stated whether they thought military strategies in Vietnam were wrong or even if the war itself was wrong.

Some literary scholars in the 1980's believed that veteran-authored Vietnam War literature, because it generally eschewed glorification of warfare, was the best hope in stemming resurgent militarism and preventing the U.S. from falling into future Vietnamlike military quagmires. This, of course, has not happened. The United States became involved in three major wars after the 1980's: The 1991 Persian Gulf War and, following the terrorist attacks of September 11, 2001, the conflicts in Afghanistan and Iraq. It is too

\footnotetext{
${ }^{6}$ Blight, Race and Reunion, 185-186.
} 
soon to know whether there will be a future "hibernation" period for the personal and collective memories of these conflicts. But for the moment, anyway, some veterans of these later conflicts have been willing to tell their stories, and the public has been willing to listen. Several memoirs written by veterans of the wars in Iraq and Afghanistan have been critically and commercially successful.

Many veteran-authors who served in post-Vietnam conflicts relate wartime experiences that are strikingly similar to those chronicled in Vietnam veteran memoirs. GIs in Vietnam battled Vietcong fighters who regularly used guerrilla tactics. Although post-Vietnam memoirists fought in Middle-Eastern deserts rather than Southeast-Asian jungles, they describe a similar combat environment. Whereas GIs in Vietnam feared landmines planted on foot-trails in the "bush," U.S. troops in Afghanistan and Iraq would warily watch the roadsides for IEDs (improvised explosive devices), ever fearful that the wrong step could be fatal. Vietnam veteran narratives are full of references to Vietcong snipers. It is fitting, then, that Nathaniel Fick notes in his memoir, One Bullet Away: The Making of a Marine, that being pinned down by seemingly invisible snipers conformed to his idea of what "Vietnam" must have been like. ${ }^{7}$ Lewis B. Puller described one particularly land-mine-infested area of South Vietnam, which his terrified men had to traverse day after day, as "living hell." Kayla Williams reveals in her memoir, Love My Rifle More Than You: Young and Female in the U.S Army, that a similar psychological strain was caused by IEDs. Williams' mind had become so fixated on the threat of IEDs

\footnotetext{
${ }^{7}$ Nathaniel Fick, One Bullet Away: The Making of a Marine Officer (New York: Mariner Books, 2005), 205.
} 
in Iraq that she could not stop herself looking for them while driving on American highways. $^{8}$

As guerrilla fighters, the Vietcong lived and fought among the civilian population. Several Vietnam veteran memoirists related instances in which GIs--sometimes the authors themselves--accidentally wounded or killed civilians during a firefight in a populated area. The soldiers who made such horrible mistakes were always portrayed as overcome with guilt and shame. Fick admits that he and his men once shot two Iraqi shepherd boys that they had mistaken for Iraqi soldiers. The whole platoon was extremely upset about the accident, and Fick reveals that it took great strength to stop himself from crying over the incident. This scene is reminiscent of an incident included in Ron Kovic's well-known Vietnam memoir, Born on the Fourth of July. Fick's terrible mistake occurred because he mistook the shepherd's staffs for weapons. ${ }^{9}$ Kovic and his men opened fire on a village after mistaking fishermen with their poles for Vietcong with guns.

Since the Vietcong lived among civilians, and basically looked identical to civilians, they were difficult to find. One of the most common scenes in Vietnam veteran narratives is GIs looking for Vietcong in villages but finding only uncooperative women and children. Fick describes an incident that is nearly identical to these scenarios. Fick's platoon searched a village and determined that enemy fighters had recently been there. But the only inhabitants of the village, a group of scared and evasive women and

\footnotetext{
${ }^{8}$ Kayla Williams with Michael E. Staub, Love My Rifle More Than You: Young and Female in the U.S. Army (New York: W.W. Norton, 2005; 2006), 281.

${ }^{9}$ Fick, One Bullet Away, 238-240.
} 
children, claimed they knew nothing about insurgent whereabouts. ${ }^{10}$ Vietnam memoirists said that they were shocked to see Vietnamese women and children actively aiding, even fighting alongside the Vietcong at times. David Bellavia relates in his memoir, House to House: An Epic Memoir of War, that he once contemplated shooting an unarmed Iraqi boy because the child was relaying American troop movements to insurgents during a firefight. $^{11}$

Like their Vietnam-era counterparts, Iraq and Afghanistan memoirists are not afraid to use the profane language employed by soldiers or to describe wounds and corpses in shocking detail. Anthony Swofford, who served as a Marine sniper in America's first war against Iraq, admits in his memoir, Jarhead: A Marine's Chronicle of the Gulf War and Other Battles, that his platoon did not see much combat overseas. Swofford, however, did see scores of Iraqi bodies incinerated by American air power; he describes them as covered with maggots and having mouths "open in agony, a death scream halted."12 Bellavia similarly writes of "shattered bodies" with "vacant corpse eyes, bulging and horror-struck."13 Such gruesome scenes echo Philip Caputo's accounts of maimed Vietcong bodies in A Rumor of War, or Lynda Van Devanter's hard-to-read descriptions of the hideously wounded GIs she cared for as an Army nurse in South Vietnam.

\footnotetext{
${ }^{10}$ Ibid., 248
}

${ }^{11}$ David Bellavia and John R. Bruning, House to House: An Epic Memoir of War (New York: Free Press, 2007), 10.

12 Anthony Swofford, Jarhead: A Marine's Chronicle of the Gulf War and Other Battles (New York: Scribner, 2003), 238.

${ }^{13}$ Bellavia and Bruning, House to House, 2. 
This candor extends to a willingness to write about events that put American soldiers, their attitudes, and behavior in a poor light. Swofford, like the Vietnam veteran memoirists, suggests that the environment of the Marine Corps in the early 1990's was blatantly sexist and misogynistic. Much like Vietnam-era GIs, the Marines quoted in Jarhead trade stories about drunken visits to prostitutes and express hatred of women who send "Dear John" letters to boyfriends and husbands stationed in the Middle East. ${ }^{14}$ Williams claims that this type of behavior was rampant in the Army as well. GIs, she says, saw all U.S. servicewomen as only one of two things: a "bitch" or a "slut."15 Williams herself was nearly raped by a fellow soldier in Iraq, but she never reported the incident because she assumed her male comrades would ostracize her if she took such an action. $^{16}$

Vietnam veteran memoirists say that the frustrations of guerilla warfare and other factors led many GIs to hold racist anti-Vietnamese attitudes. Memoirists frankly reported that American soldiers, as a rule, referred to Vietnamese, both civilians and combatants, as "gooks," "slopes," and other racist labels. Williams asserts that many GIs regarded all Iraqis, noncombatants included, as subhuman "ragheads" and "camel jockeys" whose country should be "nuked."17 In Vietnam, according to many memoirists, the dehumanization of the Vietnamese by American troops sometimes led to the mutilation of enemy corpses by GIs. Swofford says in Jarhead that some American soldiers tasked with searching destroyed Iraqi bunkers took out their frustrations on the

\footnotetext{
${ }^{14}$ Swofford, Jarhead, 68-69.

${ }^{15}$ Williams, with Staub, Love My Rifle More Than You, 13.

${ }^{16}$ Ibid., 207-210.

${ }^{17}$ Ibid., 200.
} 
blackened bodies so often found inside. One disturbed member of Swofford's platoon punctured and hacked an enemy skull over the course of a few days until he was ordered to stop. ${ }^{18}$

Vietnam veteran memoirists sometimes claimed that their books were apolitical, but most of these authors still made unambiguous statements about how they felt about the war's larger issues. To be sure, some former POW authors voiced unambiguous support for America's cause in Vietnam; but many more memoirists criticized the war as foolhardy or even immoral. This willingness to bluntly state political opinions is mirrored in post-Vietnam memoirs. Swofford periodically mentions in Jarhead that he and his comrades assumed that they were sent to the Middle East to protect the oil interests of American corporations and wealthy Kuwaitis. ${ }^{19}$ Williams had ambiguous feelings about her participation in the 2003 invasion of Iraq because she believes it was predicated on "lies" about weapons of mass destruction (WMDs) allegedly held by the Saddam Hussein regime. ${ }^{20}$ Bellavia, in contrast, came home from Iraq in 2003 as a supporter of the war, believing that he had fought to free Iraq from "tyranny and oppression." ${ }^{21}$ Although convinced, however, that the war he had fought in was a "noble effort," Bellavia still feared that the Iraq conflict "may end ignobly."22

Often, Vietnam veterans concluded their memoirs with lengthy discussions of their return to civilian lives. Many veterans admit that they came home with serious war-

\footnotetext{
${ }^{18}$ Swofford, Jarhead, 238-240.

${ }^{19}$ Swofford, Jarhead, 11, 63-65, 240-241.

${ }^{20}$ Williams, with Staub, Love My Rifle More Than You, 282.

${ }^{21}$ Bellavia and Bruning, House to House, 300.

${ }^{22}$ Ibid., 289
} 
related psychological problems, including those resembling post-traumatic stress disorder (PTSD). Such authors complained, among other things, that they were jumpy, had nightmares, and encountered difficulty in relating to loved ones. Post-Vietnam veteran memoirists report many of these same problems. Both Fick and Williams both say that they still jump at the sound of fire-crackers and continue to reflexively search for insurgent ambushes and IEDs on American highways, behavior that mirrors the behavior of the Vietnam War memoirists who scanned for Vietcong booby-traps years after their combat tours ended. ${ }^{23}$ In the final chapter of Jarhead, Swofford, echoing Vietnam veterans who felt alienated from the civilian world after their tours, laments: "In crowded rooms and walking the streets of our cities, I am alone and full of despair.",24

Besides experiencing psychological problems, post-Vietnam memoirists, like many of their Vietnam-era counterparts, say they had difficulty relating to nonveterans when they came home. Williams says that she returned home feeling that American civilians were stupid, selfish, and unappreciative of members of the armed forces who had served in Iraq. She became embarrassed and irritated when strangers, upon hearing she was a veteran, thanked her for serving and inevitably asked: "What was it like?"25 Such scenes are reminiscent of Vietnam veterans' stories of being asked by clueless nonveterans if they had killed anyone "over there." Fick served briefly in Afghanistan in the months following the September 11, 2001 terrorist attacks. After coming back to the United States following that short mission he was dismayed by the "flag-waving, tough

${ }^{23}$ Fick, One Bullet Away, and Williams, 262-263. Williams, with Staub, Love My Rifle More Than You, 281-282.

${ }^{24}$ Swofford, Jarhead, 254.

${ }^{25}$ Williams, with Staub, Love My Rifle More Than You, 274-276. 
talk" and jingoism displayed by many of his countrymen. People were "quiet and deferential" when Fick mentioned that he had served in Afghanistan, but "they seemed disappointed that [he] didn't share in the general bloodlust."26

Vietnam and post-Vietnam memoirs are similar to each other partly because the conflicts they chronicle were alike in many ways. American soldiers faced enemies in Iraq and Afghanistan, for example, who used tactics reminiscent of those employed by the Vietcong against GIs decades earlier. But these two groups of narratives are also likely similar because Vietnam veteran writers set an example of realism and candor for future veteran-authors to follow. Unlike many Civil War memoirists, the veteran-authors of the Vietnam conflict emerged from their own post-war "hibernation" willing and able to produce brutally graphic depictions of warfare. ${ }^{27}$ Vietnam narratives may not have prevented later American military interventions, but their "tell-all" style has made it easier for the men and women who have fought in these conflicts to tell their war stories. Without the example of the Vietnam veteran-authors, Swofford, Fick, Williams, Bellavia, and other post-Vietnam veteran-authors may not have produced such informative narratives. Vietnam memoirs have many faults, but by "telling it like it was" and encouraging latter generations of ex-soldiers to do the same, they have enriched both historians' and ordinary readers' understanding of the true nature of war.

\footnotetext{
${ }^{26}$ Fick, One Bullet Away, 143.

${ }^{27}$ Vietnam veteran authors were aided in their quest to "tell it like it was" by a new willingness of publishers in the post-Vietnam era to issue books containing material once considered too obscene for publication. Samuel Hynes, The Soldiers' Tale: Bearing Witness to Modern War (New York: Allen Lane/The Penguin Press, 1997), 181.
} 


\section{BIBLIOGRAPHY}

\section{PRIMARY VETERAN NARRATIVE GROUP}

Anderson, Charles R. The Grunts. San Rafael, CA: Presidio Press, 1976.

Anderson, Charles R. Vietnam: The Other War. Novato, CA: Presidio Press, 1982.

Anton, Frank with Tommy Denton. Why Didn't You Get Me Out?: A POW's Nightmare in Vietnam (New York: St. Martin's Press, 2000).

Alavarez Jr., Everett and Anthony S. Pitch. Chained Eagle. New York: Donald I. Fine, 1989.

Baker, Mark. Nam: The Vietnam War in the Words of the Soldiers Who Fought There. New York: William and Morrow, 1981; Berkley Books, 1983.

Bradford, Alfred S. Some Even Volunteered: The First Wolfhounds Pacify Vietnam. Westport, CT: Praeger Publishing, 1994.

Brennan, Matthew. Brennan's War: Vietnam 1965-69. Novato, CA: Presidio Press, 1985.

Broyles, Jr., William. Brothers in Arms: A Journey from War to Peace. New York: Alfred A. Knopf, 1986.

Callaway, Jr., Joseph W. Mekong First Light. New York: Presdio Press/Ballantine Books, 2004.

Calley, William. Lieutenant Calley: His Own Story. New York: Viking, 1971.

Caputo, Philip. A Rumor of War. New York: Holt, Rinehart and Winston, 1977; Owl Books, 1996.

Clark, Johnnie M. Guns Up!. New York: Ballantine Books, 1984; 2002.

Denton, Jeremiah. When Hell Was in Session. New York: Reader's Digest Press, 1976.

Donovan, David. Once a Warrior King: Memories of an Officer in Vietnam. New York: McGraw-Hill, 1985.

Downs, Frederick. The Killing Zone: My Life in the Vietnam War. New York: WW Norton \& Company, 1978. 
Downs, Frederick. Aftermath: A Soldier's Return to America from Vietnam. New York: Norton, 1984.

Downs, Frederick. No Longer Enemies, Not Yet Friends: An American Soldier Returns to Vietnam. New York: Norton, 1991.

Duncan, Donald. The New Legions. New York: Random House, 1967.

Ehrhart, W.D. Vietnam-Perkasie: A Combat Marine Memoir. Jefferson, NC: McFarland, 1983; reprint, Amherst, MA: University of Massachusetts Press, 1995.

Ehrhart, W.D. Passing Time: Memoir of a Vietnam Veteran Against the War (Amherst, MA: University of Massachusetts Press, 1995. Originally published as Marking Time. New York: Avon Books, 1986.

Ehrhart, W.D. Busted: A Vietnam Veteran in Nixon's America. Amherst, MA: University of Massachusetts Press, 1995.

French, Albert. Patches of Fire: A Story of War and Redemption. New York: Anchor Books, 1997.

Goff, Stanley Robert Sanders, and Clark Smith, Brothers: Black Soldiers in the Nam. Novato, CA: Presdio Press, 1982.

Guarino, Larry. A POW’s Story: 2801 Days in Hanoi. New York: Ivy, 1990.

Hackworth, David H. and Julie Sherman. About Face. New York: Simon and Schuster, 1989.

Heinemann, Larry. Black Virgin Mountain: A Return to Vietnam. New York: Doubleday, 2005.

Hemphill, Robert. Platoon, Bravo Company. Fredericksburg, VA: Sergeant Kirkland's Press, 1998; St. Martin's Paperbacks, 2001.

Kane, Rod. Veteran's Day: A Combat Odyssey. New York: Orion; Pocket Book, 1990.

Kerrey, Bob. When I Was a Young Man: A Memoir. New York: Harcourt, 2002.

Ketwig, John. And a Hard Rain Fell: A G.I. 's True Story of the War in Vietnam. New York: Macmillian, 1985.

Kidder, Tracy. My Detachment: A Memoir. New York: Random House, 2005.

Kovic, Ron. Born on the Fourth of July. New York: McGraw Hill, 1976; reprint, New York: Akashic, 2005).

Lanning, Michael Lee. The Only War We Had: A Platoon Leader's Journal of Vietnam. New York: Ivy Books, 1987. 
Lanning, Michael Lee. Vietnam, 1969-1970: A Company Commander's Journal. Ballantine Books, 1988, College Station, TX: Texas A\&M University Press, 2007.

Marcinko, Richard. Rogue Warrior. New York: Pocket Books, 1992).

Mason, Robert. Chickenhawk. New York: Viking, 1983; Penguin, 2005.

Mason, Robert. Chickenhawk Back in the World: Life After Vietnam. New York: Viking, 1993.

McCain, John. Faith of My Fathers. New York: Random House, 1999.

McDonough, James R. Platoon Leader. Novato, CA: Presidio, 1985.

Nasmyth, Spike. 2,355 Days: A POW's Story. New York: Orion, 1991.

Norman, Michael. These Good Men: Friendships Forged from War. New York: Crown Publishers, 1989.

O’Brien, Tim. If I Die in a Combat Zone, Box Me Up and Ship Me Home. New York: Delacorte Press, 1973; Delta, 1989.

Ogden, Richard E. Green Knight, Red Mourning. New York: Zebra, 1985; Pinnacle Books, 2002.

Parks, David. G.I. Diary. New York: Harper and Row, 1968; reprint, Washington, DC: Howard University Press, 1984.

Powell, Colin. My American Journey. New York, Random House, 1995.

Puller, Jr., Lewis B. Fortunate Son. New York: Grove Weindenfeld, 1991.

Risner, Robinson. The Passing of the Night: My Seven Years as a Prisoner of the North Vietnamese. Old Saybrook, CT: Konecky \& Konecky, 1973.

Rowe, James N. Five Years to Freedom. Boston: Little, Brown, 1971; New York: Ballantine/Presidio Press, 2005.

Santoli, Al. Everything We Had: An Oral History of the Vietnam War by Thirty-Three American Soldiers Who Fought It. New York: Random House, 1981; Ballantine, 1983.

Smith, Winnie. American Daughter Gone to War: On the Frontlines with an Army Nurse in Vietnam. New York: William and Morrow, 1992; Pocket Books, 1994.

Stockdale, James and Sybil Stockdale. In Love and War: The Story of a Family's Ordeal and Sacrifice During the Vietnam Years. New York: Harper \& Row, 1984.

Terry, Wallace. Bloods: An Oral History of the Vietnam War by Black Veterans. New York: Random House, 1984. 
Tripp, Nathaniel. Father, Soldier, Son: Memoir of a Platoon Leader in Vietnam. South Royalton, Vermont: Steerforth Press, 1996.

Van Devanter, Lynda with Christopher Morgan, Home Before Morning: The Story of an Army Nurse in Vietnam. New York: Beaufort Books, 1983.

Weigl, Bruce. The Circle of Hahn: A Memoir. New York: Grove Press, 2000.

Westmoreland, William C. A Soldier Reports. Garden City, NY: Doubleday, 1976.

Wolff, Tobias. In Pharoah's Army: Memories of the Lost War. New York: Alfred A. Knopf, 1994.

Yezzo, Dominick. A GI’s Vietnam Diary. New York: Franklin and Watts, 1974.

\section{OTHER PRIMARY SOURCES}

Baughman, Ronald. Interview with W.D. Ehrhart (6 June 1991). In Dictionary of Literary Biography Documentary Series, vol. 9, American Writers of the Vietnam War, ed. Ronald Baughman, 63-82. Detroit, MI: Gale Research Inc., 1991.

Bellavia, David and John R. Bruning. House to House: An Epic Memoir of War. New York: Free Press, 2007.

Benavidez, Roy B. and Oscar Griffin. The Three Wars of Roy Benavidez. San Antonio, TX: Corona Publishing Company, 1986.

Birdwell, Dwight W. A Hundred Miles of Bad Road: An Armored Cavalryman in Vietnam, 1967-1968. Novato, CA: Presidio Press, 2000.

Chanoff, David and Doan Van Toai. Portrait of the Enemy. New York: Random House, 1986.

Cummings, Delano. Moon Dash Warrior: The Story of an American Indian in Vietnam, a Marine from the Land of the Lumbee. Livermore, Maine: Signal Tree Publications, 1998, 2001.

Daly, James A. and Lee Bergman. Black Prisoner of War: A Conscientious Objector's Vietnam Memoir. Lawrence, KS: University Press of Kansas, 2000. Originally published as A Hero's Welcome: The Conscience of Sergeant James Daly Versus the U.S. Army. Indianapolis, IN: Bobbs-Merrill, 1975.

Dead Presidents. Directed by Albert Hughes and Allen Hughes (1995).

Del Rosario, Carina A., ed. A Different Battle: Stories of Asian Pacific American Veterans. Seattle, WA: Wing Luke Asian Museum, 1999. 
Duncan, Donald. “The Whole Thing Was a Lie!.” Ramparts 4, no. 10 (February 1966), pp. 12-24.

Emanuel, Ed. Soul Patrol. New York: Ballantine Books, 2003.

Enthoven, Alain. Memorandum for Secretary of Defense, 4 May 1967, The Pentagon Papers, 462. In Bringing the War Home: The American Soldier in the Vietnam and After, John Helmer, 26. New York: The Free Press, 1974.

Fick, Nathaniel. One Bullet Away: The Making of a Marine Officer. New York: Mariner Books, 2005.

Garcia, Manny. An Accidental Soldier: Memoirs of a Mestizo in Vietnam. Alberquerque, NM: University of New Mexico Press, 2003.

Gillam, James T. War in the Central Highlands of Vietnam, 1968-1970: A Historian's Experience. Lewiston, NY: The Edwin Mellen Press, 2006.

Greene, Bob. Homecoming: When the Soldiers Returned from Vietnam. New York: Putnam, 1989.

Hamburger Hill. Directed by John Irvin (1987).

Hampton, Lynn. The Fighting Strength: Memoirs of a Combat Nurse in Vietnam. Canton, OH: Daring Books, 1990; reprint, New York: Warner Books, 1992.

Hayslip, Le Ly and Jay Wurts. When Heaven and Earth Changed Places. New York: Doubleday, 1989.

Hess, Martha. Then the Americans Came: Voices from Vietnam. New York: Four Walls Eight Windows, 1993.

Jackson, Jr., James E. “18 Months as a Prisoner of the Vietcong.” Ebony, August 1968, 114-119.

Marshall, Kathryn. In the Combat Zone: An Oral History of American Women in Vietnam, 1966-1975. Boston: Little, Brown, 1987.

O’Brien, Tim. "How to Tell a True War Story." In The Things They Carried: A Work of Fiction. New York: Houghton Mifflin, 1990; Mariner Books, 2009, 64-81.

Powell, Mary Reynolds. A World of Hurt: Between Innocence and Arrogance in Vietnam. Cleveland, OH: Greenleaf Enterprises, 2000. 
"Record Counts by Age and Time of Death or Declaration of Death," Combat Area Casualties Current File (CACCF). National Archives and Records Administration. Obtained from www.archives.gov.

Swofford, Anthony. Jarhead: A Marine's Chronicle of the Gulf War and Other Battles. New York: Scribner, 2003.

TeCube, Leroy. A Year in Nam: A Native American Soldier's Story. Lincoln, NB: University of Nebraska Press, 1999.

The Walking Dead. Directed by Preston A. Whitmore II (1995).

“Transcript: Kerry Testifies Before Senate Panel, 1971.” From NPR.org, 25 April 2006, obtained 12 Dec. 2008.

Trujillo, Charley. Soldados: Chicanos in Vietnam. San Jose, CA: Chusma House Publishers, 1990.

U.S. Commissioner of Immigration and Naturalization. Annual Reports, 1947-75. In "Asian Wives of U.S. Servicemen: Women in the Shadows," Bok-Lim Kim, Amerasia 4, no.1 (1977): 91-115.

Vance, Samuel. The Courageous and the Proud. New York: W.W. Norton and Company, 1970 .

Whitmore, Terry and Richard P. Weber. Memphis, Nam, Sweden: The Story of a Black Deserter. New York: Doubleday, 1971; reprint, Jackson, MI: University Press of Mississippi, 1997.

Williams, Fenton A. Just Before the Dawn: A Doctor's Experiences in Vietnam. New York: Exposition Press, 1971.

Williams, Kayla with Michael E. Staub. Love My Rifle More Than You: Young and Female in the U.S. Army. New York: W.W. Norton, 2005; 2006.

Ybarra, Lea, ed. Vietnam Veteranos: Chicanos Recall the War. Austin, TX: University of Texas Press, 2004.

\section{MAGAZINES AND NEWSPAPERS}

Ebony

Esquire 
Harper's

Jet

Nation

National Review

New Republic

New York Times

Publishers Weekly

Time

Vanity Fair

Washington Post

\section{SECONDARY SOURCES: BOOKS AND ARTICLES}

Anderson, Terry H. The Movement and the Sixties. New York: Oxford University Press, 1995.

Appy, Christian G. Working-Class War: American Combat Soldiers and Vietnam Working-Class War: American Combat Soldiers and Vietnam. Chapel Hill, NC: The University of North Carolina Press, 1993.

Bailey, Beth. Sex in the Heartland. Cambridge, MA: Harvard University Press, 1999.

Baritz, Loren. Backfire: A History of How American Culture Led Us into Vietnam and Made Us Fight the Way We Did. New York: William Morrow, 1985.

Baskir, Lawrence M. and William A. Strauss. Chance and Circumstance: The Draft, the War and the Vietnam Generation. New York: Alfred A. Knopf, 1978; Vintage Books, 1978.

Beamish, Thomas D., Harvey Molotch, and Richard Flacks. "Who Supports the Troops? Vietnam, The Gulf War, and the Making of Collective Memory." Social Problems 42, no. 3 (August 1995): 344-360.

Beavers, Herman. "Contemporary Afro-American Studies and the Study of the Vietnam War." Vietnam Generation 1, no. 2 (1989): 6-13. 
Beidler, Philip D. American Literature and the Experience of Vietnam. Athens, GA: University of Georgia Press, 1982.

Beidler, Philip D. Re-Writing America: Vietnam Authors in Their Generation. Athens, GA: University of Georgia Press, 1991.

Beidler, Philip D. Late Thoughts on an Old War: The Legacy of Vietnam. Athens, GA: University of Georgia Press, 2004.

Bleakney, Julia. Revisiting Vietnam: Memoirs, Memorials, Museums. New York: Routledge, 2006.

Blight, David W. Race and Reunion: The Civil War in American Memory. Cambridge, MA: Belknap/Harvard University Press, 2001.

Boose, Lynda. "Techno-Muscularity and the "Boy Eternal": From the Quagmire to the Gulf." In Cultures of United States Imperialism, eds. Amy Kaplan and Donald E. Pease, 581-617. Durham, NC: Duke University Press, 1993.

Brigham, Robert K. ARVN: Life and Death in the South Vietnamese Army. Lawrence, KS: University Press of Kansas, 2006.

Brownmiller, Susan. Against Our Will: Men, Women, and Rape. New York: Fawcett Columbine, 1975.

Childers, Thomas. Soldier from the War Returning: The Greatest Generation's Troubled Homecoming from World War II. Boston: Houghton Mifflin Harcourt, 2009.

Clifton, Merritt. Those Who Were There: Eyewitness Accounts of the War in Southeast Asia, 1956-1975, \& Aftermath. Paradise, CA: Dustbooks, 1984.

Cortright, David. Soldiers in Revolt: The American Military Today. New York: Anchor Press, 1975.

Culter, John Alba. "Disappeared Men: Chicana/o Authenticity and the American War in Viet Nam." American Literature 81, no. 3 (September 2009), 583-611.

Dean, Jr., Eric T. Shook Over Hell: Post-Traumatic Stress, Vietnam, and the Civil War. Cambridge, MA: Harvard University Press, 1997.

D'Emilio, John and Estelle B. Freedman. Intimate Matters: A History of Sexuality in America. New York: Harper and Row, 1998.

Dickson, Paul and Thomas B. Allen. The Bonus Army: An American Epic. New York: Walker and Company, 2004. 
Dower, John W. War Without Mercy: Race and Power in the Pacific War. New York: Pantheon Books, 1986.

Dower, John. Embracing Defeat: Japan in the Wake of World War II. New York: W.W. Norton \& Company, 1999.

Engelhardt, Tom. The End of Victory Culture: Cold War America and the Disillusioning of a Generation. New York: Basic Books, 1995.

Feeny, Paul and Jim Allaway. "The Ecological Impact of the Air War." In Vietnam and America: A Documented History, eds. Marvin E. Gettleman and others, 461-469. New York: Grove Press, 1985.

Fitzgerald, Frances. Fire in the Lake: The Vietnamese and the Americans in Vietnam. Boston: Little, Brown and Company, 1972.

Foner, Jack D. Blacks and the Military in American History: A New Perspective. New York: Praeger, 1974.

Franklin, H. Bruce. Vietnam and Other American Fantasies. Amherst, MA: University of Massachusetts, 2000.

Gabriel, Richard A. and Paul L. Savage. Crisis in Command: Mismanagement in the Army. New York: Hill and Wang, 1978.

Gambone, Michael D. The Greatest Generation Comes Home: The Veteran in American Society. College Station, TX: Texas A\&M University Press, 2005.

Gitlin, Todd. The Whole World is Watching: Mass Media in the Making \& Unmaking of the New Left. Berkeley, CA: University of California Press, 2003.

Goldman, Peter. Reportf from Black America. New York: Simon and Schuster, 1970.

Graham, Don. No Name on the Bullet: A Biography of Audie Murphy. New York: Viking, 1989.

Graham, Herman. The Brothers' Vietnam War: Black Power, Manhood, and the Military Experience. Gainesville, FL: University Press of Florida, 2003.

Guzman, Ralph. "Mexican American Casualties in Vietnam.” La Raza 1, no. 1 (1971): 12-15.

Helmer, John. Bringing the War Home: The American Soldier in the Vietnam and After. New York: The Free Press, 1974. 
Herring, George C. America's Longest War: The United States and Vietnam, 1950-1975. New York: John Wiley \& Sons, 1979.

Herring, George C. "Vietnam Remembered.” Journal of American History 73, no. 1 (June 1986): 152-164.

Hersh, Seymour M. My Lai 4: A Report on the Massacre and its Aftermath. New York: Random House, 1970.

Herzog, Tobey C. Vietnam War Stories: Innocence Lost. New York: Routledge, 1992.

Holm, Tom. Strong Hearts, Wounded Souls: Native American Veterans of the Vietnam War. Austin, TX: University of Texas Press, 1996.

Howes, Craig. Voices of the Vietnam P.O.W.s: Witnesses to their Fight. New York: Oxford University Press, 1993.

Hynes, Samuel. The Soldiers' Tale: Bearing Witness to Modern War. New York: Allen Lane/The Penguin Press, 1997.

Huntington, Samuel P. The Soldier and the State: The Theory and Politics of CivilMilitary Relations. Cambridge, MA: The Belknap Press of Harvard University Press, 1964.

Janowitz, Morris. The Professional Soldier: A Social and Political Portrait. Glencoe, IL: The Free Press, 1960.

Jason, Philip K., ed. Fourteen Landing Zones: Approaches to Vietnam War Literature. Iowa City, IA: University of Iowa Press, 1991.

Jeffords, Susan. The Remasculinization of America: Gender and the Vietnam War. Indianapolis, IN: Indiana University Press, 1989.

Joseph, Peniel E. Waiting 'Till the Midnight Hour: A Narrative of Black Power in America. New York: Henry Holt and Company, 2006.

Kimbrough, Natalie. Equality or Discrimination?: African Americans in the U.S. Military During the Vietnam War. Lanham, MD: University Press of America, 2007.

Kindsvatter, Peter S. American Soldiers: Ground Combat in the World Wars, Korea, and Vietnam. Lawrence, KS: Kansas University Press, 2003.

Kinsey, Alfred C. Wardell B. Pomeroy, and Clyde E. Martin. Sexual Behavior in the Human Male. Philadelphia: W.B. Saunders Company, 1948. 
Kitsch, Carolyn. Pages from the Past: History and Memory in American Magazines. Chapel Hill, NC: The University of North Carolina Press, 2005.

Knightly, Philip. The First Casualty: The War Correspondent as Hero and Myth-Maker from the Crimea to Iraq. Baltimore, MD: The Johns Hopkins University Press, 2004.

Kozloff, Nikolas. "Vietnam, the African American Community, and the Pittsburgh New Courier." Historian 63 (Spring 2001): 521-538.

Kulka, Richard A. and others, Trauma and the Vietnam War Generation: Report of Findings from the National Vietnam Veterans Readjustment Study. New York: Brunner/Mazel, 1990.

Kusmer, Kenneth L. Down and Out, On the Road: The Homeless in American History. New York: Oxford University Press, 2002.

Lawson, Jacqueline. "She's a Pretty Woman . . . for a Gook:' The Mysogyny of the Vietnam War." In Fourteen Landing Zones: Approaches to Vietnam War Literature, ed. Philip K. Jason, 17-34. Iowa City, IA: University of Iowa Press, 1991.

Legacies of Vietnam: Comparative Adjustment of Veterans and their Peers. Washington: United States Government Printing Office, 1981.

Lembke, Jerry. The Spitting Image: Myth, Memory, and the Legacy of Vietnam. New York: New York University Press, 1998.

Linderman, Gerald F. Embattled Courage: The Experience of Combat in the American Civil War. New York: The Free Press, 1987.

Loeb, Jeff. "MIA: African American Autography of the Vietnam War." African American Review 31, no. 1 (Spring 1997): 105-123.

Lomperis, Timothy J. "Reading the Wind": The Literature of the Vietnam War. Durham, NC: Duke University Press, 1987.

Loory, Stuart H. Defeated: Inside America's Military Machine. New York: Random House, 1973.

Louvre, Alf and Jefferey Walsh, ed. Tell Me Lies About Vietnam: Cultural Battles for the Meaning of the War. Philadelphia: Open University Press, 1988.

Luckett, Perry D. "The Black Soldier in Vietnam War Literature and Film." War, Literature, and the Arts 1, no.2 (1989-90): 1-27. 
Martin, Andrew. Receptions of War: Vietnam in American Culture. Norman, OK: University of Oklahoma Press, 1993.

McKelvey, Robert S. The Dust of Life: America's Children Abandoned in Vietnam (Seattle: University of Washington Press, 1999,

McNamara, Robert S. with Brian VandeMark. In Retrospect: The Tragedy and Lessons of Vietnam. New York: Times Books, 1995.

Milam, Ron. Not a Gentleman's War: An Inside View of Junior Officers in the Vietnam War. Chapel Hill, NC: The University of North Carolina Press, 2009.

Moskos, Jr., Charles C. The American Enlisted Man: The Rank and File in Today's Military. New York: Russell Sage Foundation, 1970.

Myers, Thomas. Walking Point: American Narratives of Vietnam. New York: Oxford University Press, 1988.

Myths and Realities: A Study of Attitudes Toward Vietnam Era Veterans. Washington: United States Government Printing Office, 1980.

Nelson, Deborah. The War Behind Me: Vietnam Veterans Confront the Truth About U.S. War Crimes. New York: Basic Books, 2008.

Polner, Murray. No Victory Parades: The Return of the Vietnam Veteran. New York: Holt, Rinehart and Winston, 1971.

Reeves, Michael E. M.D. and Michael J. Maxwell, M.S. "The Evolution of a Therapy Group for Vietnam Veterans on a General Psychiatry Unit.” Journal of Contemporary Psychotherapy 17, no. 1 (Spring 1987): 22-33.

Robertson, Marjorie J. "Homeless Veterans: An Emerging Problem?.” In The Homeless in Contemporary Society, eds. Richard D. Bingham, Roy E. Green, and Sammis B. White, 64-81. Newbury Park, CA: Sage Publications, 1987.

Severo, Richard and Lewis Milford. The Wages of War: When America's Soldiers Came Home from Valley Forge to Vietnam. New York: Simon and Schuster, 1989.

Shay, Jonathan. Achilles in Vietnam: Combat Trauma and the Undoing of Character. New York: Atheneum, 1994.

Shay, Jonathan. Odysseus in America: Combat Trauma and the Trials of Homecoming. New York: Scribner, 2002.

Sheehan, Neil. A Bright Shining Lie: John Paul Vann and America in Vietnam. New York: Random House, 1988. 
Sherwood, John Darrell. Black Sailor, White Navy: Racial Unrest in the Fleet During the Vietnam War Era. New York: New York University Press, 2007.

Slocock, Caroline. "Winning Hearts and Minds: The Ist Casualty Press." Journal of American Studies 16, no. 1, (1982): 107-117.

Slotkin, Richard. Gunfighter Nation: The Myth of the Frontier in Twentieth-Century America. New York: Atheneum, 1992.

Stouffer, Samuel A. Stouffer and others. The American Soldier: Combat and its Aftermath, vol. 2. Princeton, NJ: Princeton University Press, 1949.

Stuhldreher, Karen. "State Rape: Representations of Rape in Vietnam.”Vietnam Generation 5, no. 1-4 (1994).

Tal, Kali. "The Mind at War: Images of Women in Vietnam Novels by Combat Veterans." Contemporary Literature 31, no.1 (Spring 1990): 76-96.

Taylor, Sandra C. Vietnamese Women at War: Fighting for Ho Chi Minh and the Revolution. Lawrence, KS: University Press of Kansas, 1999.

Thelen, David. "Memory and American History." Journal of American History 75, no. 4 (March 1989): 1117-1129.

Tran, Nu-Anh. "South Vietnamese Identity, American Intervention, and the Newspaper Chinh Luan.” Journal of Vietnamese Studies 1, no. 1-2 (February 2006): 169209.

Turner, Karen Gottschang with Phan Thanh Hao. Even the Women Must Fight: Memories of War from North Vietnam. New York: John Wiley and Sons Inc., 1998.

Van Deburg, William L. New Day in Babylon: The Black Power Movement and American Culture, 1965-1975. Chicago: University of Chicago Press, 1992.

Terry II, Wallace. "Bringing the War Home.” Black Scholar 2 (November 1970): 6-18.

Walsh, Jeffrey. American War Literature, 1914 to Vietnam. New York: St. Martin's Press, 1982.

Wecter, Dixon. When Johnny Comes Marching Home. Cambridge, MA: Houghton Mifflin, 1944.

Westheider, James. Fighting on Two Fronts: African Americans and the Vietnam War. New York: New York University Press, 1997. 
Westheider, James. The African American Experience in Vietnam: Brothers in Arms. Lanham, MD: Rowman and Littlefield Publishers, 2008.

White, Theodore H. The Making of the President, 1968. New York: Atheneum, 1969.

Wilcox, Fred A. Waiting for an Army to Die: The Tragedy of Agent Orange. New York: Random House, 1983.

Wilson, James C. Vietnam in Prose and Film. Jefferson, NC: McFarland \& Company, 1982.

Winick, Charles and Paul M. Kinsie. The Lively Commerce: Prostitution in the United States. Chicago: Quadrangle Books, 1971.

Ybarra, Lea. "Perceptions of Race and Class among Chicano Vietnam Veterans." Viet Nam Generation 1, no. 2 (1989): 69-93.

Young, Marilyn B. The Vietnam Wars, 1945-1990. New York: HarperCollins, 1991. 